\title{
九州齒科 學會雜誌
}

昭和十年九月一日發行

$$
\text { 原著 }
$$

Aus dem pathologischen Institut und der Zahnklinik der kaiserlichen Universität, Osaka, Japan. (Leiter: Prof. Dr. A. Katase und Prof. Dr. S. Yumikura.)

Ueber die acidösen Veränderungen der Kieferknochen und inneren Zahnfleischsäume (inneres Saumepithel $u$. seine Submukosa) bei der Ueberfütterung mit gemischten Hauptnährstoffen (Causa interna der sog. Alveolarpyorrhöe)

\section{Von Dr. T. Takahashi.}

Der Verfasser beabsichtigte diese Experimente, um die Beziehungen zwischen den einseitigen Nahrungen von Hauptnährstoffen (Kohlenhydrat, Eiweiss, Fett) und Pyorrhöeneigung klar zu machen.

Experimente.

A. Versuchstier......junge, wachsende Hunde.

B. Hauptnährstoffen, die der gewöhnlichen Nahrung zugesetzt werden.

a. Kohlenhydrat $\cdots \cdot \cdot$... Rohrzucker.

b. Eiweiss.....Rindfleischpulver (entfettet).

c. Olivenöl.

C. Fütterungsweise.

Ite Gruppe : bekam täglich einen Zusatz von 5, Ogr (Rohrzucker + Eiweiss) pro Kg. Gewicht.

IIte Gruppe : bekam täglich einen Zusatz von 5, Ogr (Eiweiss + Olivenöl) pro $\mathrm{Kg}$. Gewicht.

IIIte Gruppe : bekam täglich einen Zusatz von 5, Ogr (Olivenöl + Rohrzucker) pro $\mathrm{Kg}$. Gewicht.

IVte Gruppe: bekam täglich einen Zusatz (Rohrzucker + Eiweiss + Olivenöl) pro $\mathrm{Kg}$. Gewicht.

(Bemerk : Um deutliche Veränderung hervorzurufen, wurden oftmals grosse Ueberfütterung gesetzt) 
Ueber die acidösen Veränderungen der Kieferknochen und inneren Zahnfleischsäume

2 (inneres Saumepithel $u$. seine Submukosa) bei der Uebe fütterung mit gemischten Hauptnährstoffen (Causa interna der sog. Alveolarpyorrhöe).

Ergebnisse.

\section{Veränderungen der Schmelzepithelien.}

(i) Schmelzepithel

$$
\begin{aligned}
& \text { A) inneres Schmelz- } \\
& \text { epithel (Amelo- } \\
& \text { blasten) }
\end{aligned}
$$

(I. Abnahme der Höhe der Zellen mit pyknotischer Kern.

2. retikuläre Atrophie.

3. cystenähnliche Veränderung

4. Adamantikelbildung

5. trofenartige Atrophie

6. ballonierende Degeneration, ....... grosser zelleib mit der atrophischen Kern.

7. Nekrose $\cdots$ protoplasmaaufquellung mit Karyorhexis

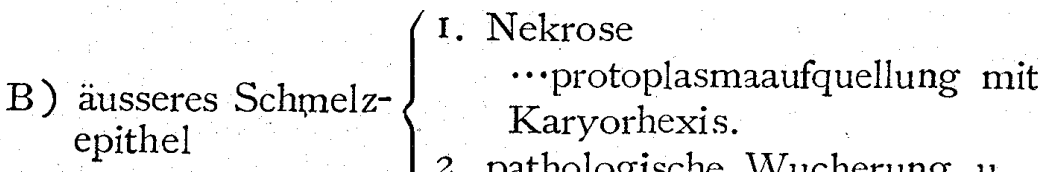

2. pathologische Wucherung $u$. cystenbildung.

(2) zellige Infiltration zur Zeit des Zahnkeimes. Infiltration der polynuclären Leukozyten in der Umgebung der nekrotischen Epithelien.

\section{Befunde des inneren Saumepithels und seiner Submukosa}

Die vereinigten Schmelzepithelien, welche zur Zeit des Zahnkeimes an Ernährungsstörungen gelitten worden waren, bilden sich wie schon erwähnt beim Durchbruch des Zahnes ein abnormes inneres Saumepithel aus, und zwar

1) inneres Saumepithel $\left\{\begin{array}{l}\text { I. cysteähnliche Veränderung. } \\ \text { 2. interepithelialer Riss. } \\ \text { 3. nekrotisches Epithel. }\end{array}\right.$

2) seine Submukosa $\cdots\left\{\begin{array}{l}\text { I. zellige Infiltration. } \\ \text { 2. Hyperämie. }\end{array}\right.$

Bemerk: Auch bei der Ernährungsstörungen entsteht die Gingivitis marginalis.

solche pathologisch veränderte innere Saumepithelien und seine Submukosa disponi eren sich natürlich zur lokalen Infektion.

3) Endlich Geschwürsbildung (ohne experimentelle Bakterienimpfung!).

\section{Befunde des Kieferknochens.}

Der Kieferknochen wurden nach dem Zahnwechsel untersucht. Trotz keines entzündlichen Zeichens am Zahnfleischrand, lockerten sich oftmals die Zähne. 

Hauptnährstoffen (Causa interna der sog. Alveolarpyorrh öe).

Röntgenologisch konnte man rauhe spongiöse Schicht od. Atrophie des Septum alveolaris nachweisen.

mikroskopich :

(1. Atrophie des Osteoblastens.

2. Vermehrung des Osteoklastens (lakunäre Resorption)

3. Erweiterung des Haversschen Kanälchens

4. gallertartige Atrophie.

5. Hyperämie od. Blutung im Knochenmark.

6. fibröse Umwandlung.

... Sog. Osteoporose.

diese osteoporotischen Erscheinungen gehen allmählich in Osteodystrophia fibrosa generalisata über, und führen zu einer Zahnlockerung.

Epikrise.

1) Ueber die Beziehungen zwischen Blutacidosis und Entwickerungsstörungen des Zahnststems sowie der Kieferknochen.

Der Verfasser hat nachfolgende Ansicht.

gesteigerte Resorption am Knochensystem

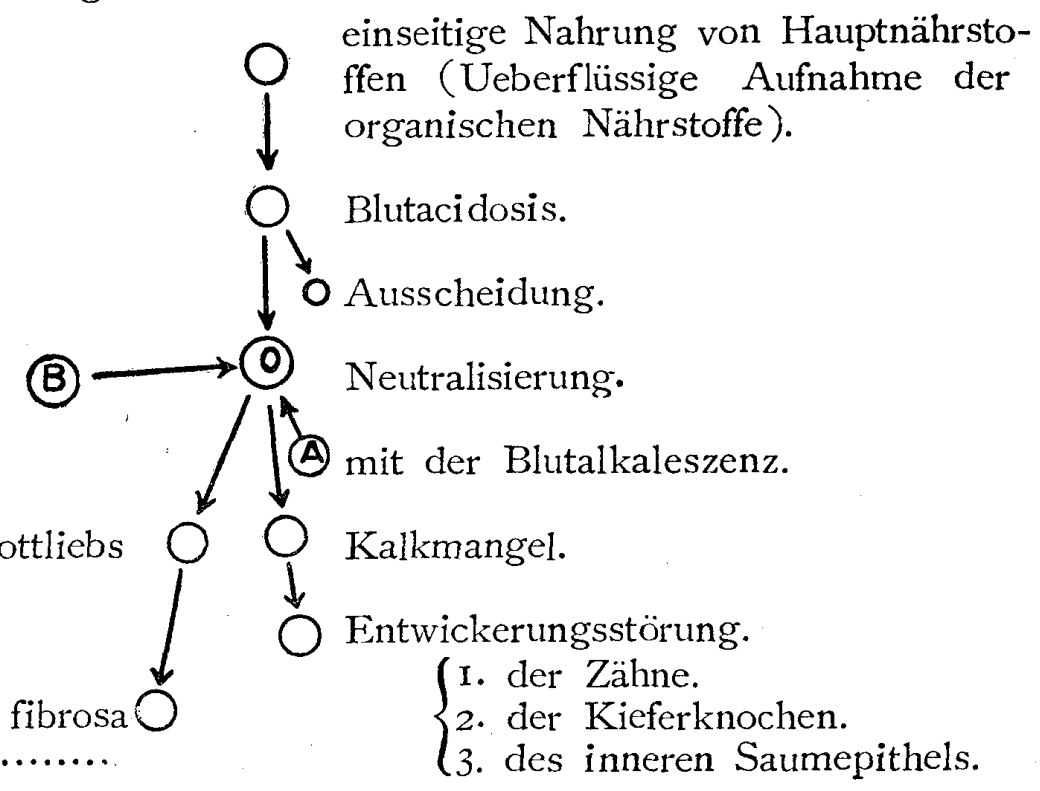

Ueberflüssige Aufnahme der organischen Nährstoffen (Kohlenhydrat, Eiweiss, Fett) ruft Blutacidosis hervor, und die im Blut gebildete überflüssige Säure muss auf zwei Wege der Ausscheidung und der Neutralisiert werden.

Um die Gleichgewicht des Alkalescenz kostant zu erhalten, muss die Säure einerseits sowhl von dem Harn wie durch das Ausatmen ausscheiden, und anderseits mit dem Alkalisalz neutralisiert werden.

Nimmt das Alkalisalz im Blut ab (A), so kommt der Gewebssaft des ganzen Körpers sekundär zu einem Kalkmangelzustand und infolgendessen werden die Zellen der Zähne und des Knochensystems bedeutend beeinträchtigt. Mit anderen 
Ueber die äciđösen Veränderungen der Kieferknochen und inneren Zahnfleischsäume (inneres Saumepithel u. seine Submukcsa) bei der Ueberfütterung mit gemischten Hauptnährstoffen (Causa interna der sog. Alvealarpyorrhöe).

Worten, werden die Alkaleszenz, die sonst in den Zähnen sowie den Knochensystemen reichlich niederzuschlagen pflegen, zur Neuttalisierung der Blutacidosis benutzt, und deshalb bekommen sekündär die Zellen der Zähne sowie Knochen die bedeutenden Ernährungsstörungen. Endlich aber die Zälne., die Kieferknochen, die inneren Saumepithelien hochgradige Entwicklungsstörungen zur Folge.

Bei mangelhafter Neutralisierung der Blutacidosis durch Blutalkaleszenz werden die ausgebildeten Knochengewebe durch die Osteoklasten resorbiert (B) und damit neutralisiert, d. h. lässt sich gesteigerte Resorption am Knochensystem bei dieser Experimente nachweisen. Anstatt des Knochens tritt eine wucherung des Bindegewebe auf, und geht es allmählich in Osteodystrophia fibrosa generalisata über, indem es zu einer Zahnlockerung kommt.

2) Ueber die Frage ber sog. Alveolarpyorrhöe.

Für die sog. Alveolarpyorrhöe ist es mannigfaltig genannt und es geben viele Theorien für deren Entstehung; aber deren Untersuchungsziel haben zwei folgende Veränderungen ausgewählt zu werden.

A) Atrophie des Kieferknochens.

B) Die Veränderungen des inneren Saumepithel und seiner Submukosa.

A) Ueber die Atrophie des Alveolarknochens.

Die traumatische Okklusion ist bisher als eine Ursache der sog. Alveolarpyorrhöe anzusehen. Dazu gehören die Belastungsparadentose und Entlastungsparadentose. Aber die durch solche äussere. Ursache hervorgerufene Veränderung des Knochens ist nur Ostitis fibrosa localisata. Dass der Verf. jetzt in Betracht zieht, ist nicht eine örtliche Veränderung des Kieferknochens, sondern eine diffuse Atrophie Gottliebs von grösser Bedeutung bei der sog. Alveolarpyorrhöe. Diese diffuse Atrophie scheint uns infolge der inneren Ursache (endogenen Faktoren vorzukommen. Schon von Seiten der inneren Sekretion sowie des Stoffwechsels wurde die untersucht, ader es war klinische und statistische Beobachtungen.

Dabei gelengen es Dr: Yamagami im Jahre 1930 durch die überflüssigen Zuckerarten und im Jahre 193 I Becks durch die Vitamin D-mangel-und kalkarme Nahrung, eine Ostitis fibrosa entstehen zu lassen. Und der Verf. liess beim deisen Experimente (ueberflüssigen Zucker, Eiweiss, Fett) eine diffese Atrophie d. h. Dystrophie alveolaris diffusa Gottliebs zustande zu kommen.

B) Befunde des innren Saumepithel und seiner Submukosa.

Von der Wichtigkeit ist bei der Untersuchung der sog. Alveoiarpyorrhöe 
Ueber die acidösen Veränderungen der Kieferknochen und inneren Zahnfleischsäume (inneres Saumepithel u. seine Sulmukcsa) kei der Ueberfütterung mit gemischten Hauptnährstoffen (Causa interna der sog. Alveolarpyorrhöe).

inneres Saumepithel und seine Submukosa. Die Untersuchung der Zahnfleischtasche bei ber Leichenpräparat ist fast vollständig geforscht, aber leider gibt es keine experimentelle Arbeit. Gerade möchte ich über diese Thema möglichst klar machen und bearbeiten.

Der Verf. verfolgte zunächst den physiologischen Durchbruch bes Zahnes, bei dem das vereinigte Schmelzepithel von der Schmelzoberfläche losgelöst und daraus kommt das innere Saumepithel zustand. Und dann beobachtete ich die Beziehungen zwischen dem pathologisch veränderten Schmelzepithel und dem inneren Saumepithel sowie seiner Submukosa (wie schon erwähnt).

Jedenfalls überzeugt sich der Verf. daran, dass die früzeitige Atorophie des Alveolarfortsatzes dei diesem Experimente zu einer Zahnlockerung sowie Taschenbildung führt und zwar eine günstige Anlage der sog, Alveolarpyorrhöe schafft. Andereseits sind meines Erachtens das innere Saumepithel und seine Submukosa, welche pathologisch verändert waren, als locus minoris resistentiae zur lokalen Infektion anzusehen. Ja, bei langdauernder Fütterung des Versuchstiers kam ein Geschwürsbildung ohne irgend eine bakterielle Impfung zustande.

Meiner Ansicht nach für die Entstehung der sog Alveolarpyorrhöe spielen natürlich die lokale Reize eine Rolle, aber hier sei betont, dass diejenige, die dazu eine grasse Disposition haben, gegen eine geringere äussere Ursache auch sehr empfindlich sind.

Deshalb erkennt der Verf., dass die Reinigung der Mundhöhle auch bei der Prophylaxie der sog. Alveolarpyorrhöe wohl nötig sei, aber es ist dafür viel mehr wichtig, festen Kieftrknochen, normales Saumepithel sowie seine Submukosa auszubilden.

Wenn man ein fester Zahn und Paradentium an sich haben will, so muss besonders im wachsenden Alter die überflüssige Nahrung von Zucker, Eiweiss, Fett vermeiden werden.

In Schlusse möchte ich Prof. Dr. A. Katase und Prof. Dr. S. Yumikura sowie Dr. J. Yamagami für ihre freundlichen Hilfe meine herzlichsten Danke sagen. 
第一回 宿 題 報 告

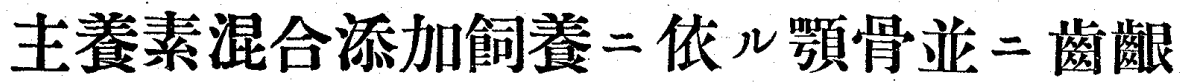 內緣上皮ノ「アチドージス性變化ニ就テ}

（所謂苳槽膿漏）內因）

大阪帝國大學醫學部病理學敉室（指尊 片瀨敉授）

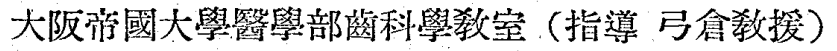

專攻生高橋 武 雄

（本篇入昭和八年度本學會宿題報告ナリ）

\section{內 容 目次}

第一章 緒 論

第二章 實 驗

第一節 實驗材料並二方法

第二蓈，標本製造法

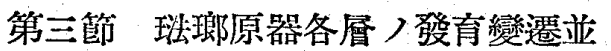
二其ノ晩期運命二就イテ

\section{第四節 實驗成績}

附圖並二附圖說明

第五節 實驗總括

第三章 考 按

第四章 紹 論

\section{第一章緒論}

凡り疾病ノ成立スル 當リテ素因及ビ誘因ノ二者ガ互二一役ヨ演ズベキハ之レ自然つ原則ナ リ。然レドモ疾病成立ノ要約ハ必ズシモ之等雨者ノ均等行至本行ヨ必要卜セズシテ素因大ナル モノ八疾病へノ感受性二富ミ、素因乏シキモノ八疾病二對シ恰モ免疫性ヨ有スルヤノ觀アリ。 事實、薄弱ナル體質ニ㟨グモイ、往タ輕微ナル誘因ニスラ感受シテ伏シテ病床ニ呻吟センモ、 强健ナル體軀ノ所有者ハョク誘因二抵抗シ得ベシ。

由是觀之、素因ノ一部八明カ二體質ト不即不離ノ關聯二立ツモノナルラ認識スルト共二、豫 防醫學つ妙諦入須ラク體軀ノ强健ヨ期シ、併セテ誘因ノ排除ニ努メザル可ラザルシ識ル。誘因 ノ排除八即チ衛生思想つ鼓吹二俟ツベキコト大ナルベク、之ガ觀念ヨ遵守シテ常二身邊つ清淨 ヨ保チ以テ疾病感染ノ機會 カヨ以デシテハ認識シ能ハザル微么體ノ活動ニ低ルモノナレバ、之ガ絕對的逃避八寧口難事二 屬セザルヤ。換言スレバ望人八不知不識ノ裡二常二疾病感染ノ機會二暴露サレツ、アリ。試ミ 二見ヨ、人類解剖ノ結果、結核感染者八實二九割强ノ高率 八必ズシモ生前つ發病者タラザリシハ實＝看過ス可ラザル事實ニシテ、發病卜否卜ハ刎論感染 


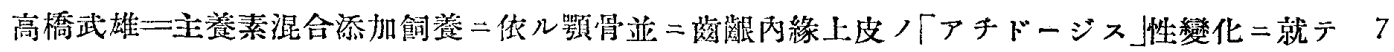

ノ大小二化ランモ、叉以テ體軀ノ强弱二左右七ラル、コト逻大ナルベシ。

以上觀ジ來レバ吾人ノ日常二於テ誘因ノ絕滅ハ期シテ望ミ難キモノナレバ寧口之二拮抗シ得

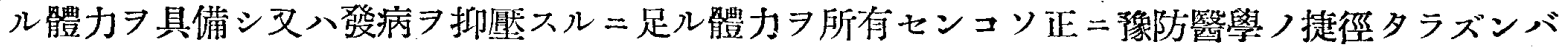

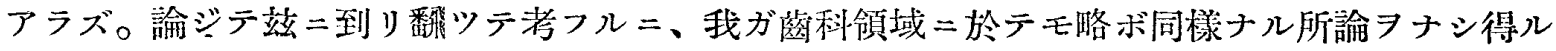

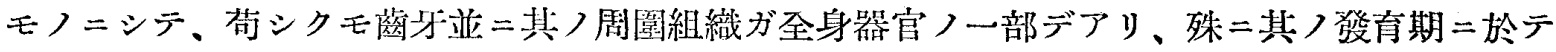

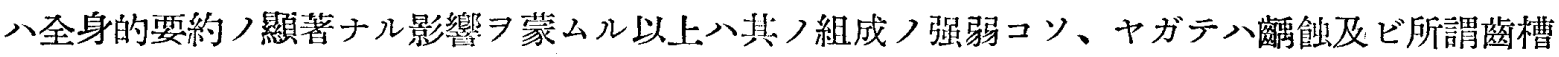
膿漏ノ發生二對シテ寧口根本義ヨ有スルニ至ランコソ極メテ容易二想像セラル、所ナリ。事實

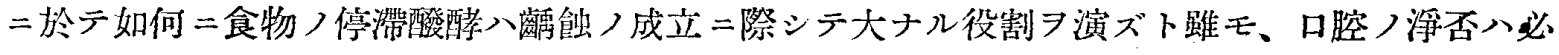

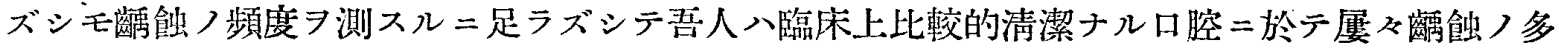
發七ルアル二遭遇ス。一方二於テ所謂悳槽膿漏モ亦必ズシモ口腔不潔者二ノミ特發セザルハ既

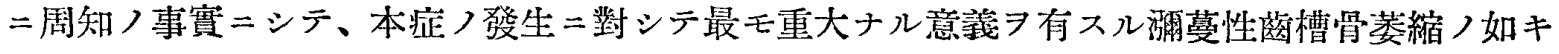
八全ク局所ノ原因ニ支配サレズシテ、全身的要約卜密接不可分ノ關聯ニ立ツモノ、如シ。

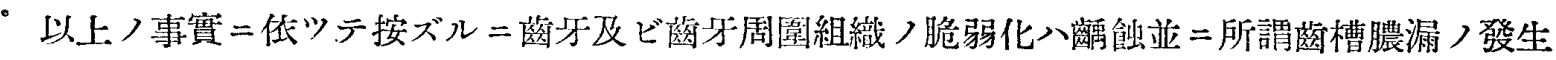
ニ對シテ重大ナル素因ヨ有スベキハ茲二贅言习要セザル所ナルベシ。余八㲏ニカ、ル見解习抱

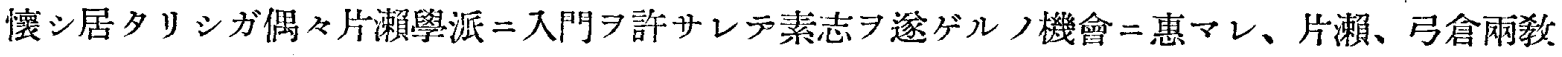
授入許ニ於テ、先ヅ偏食實驗 ルモ今回八特二所謂苳槽膿潤問題二就イテノミ報告セントスルモノナリ。

\section{第二章＼cjkstart實＼cjkstart驗 \\ 第一筇 實驗材料並二方法}

實驗動物ハ生後 40 日万至50日內外ノ幼若犬、時トシテハ 3 ケ月內外ノ仔犬 列ノミヨ有スル同腹動物ノ蒐集二努メタリ。

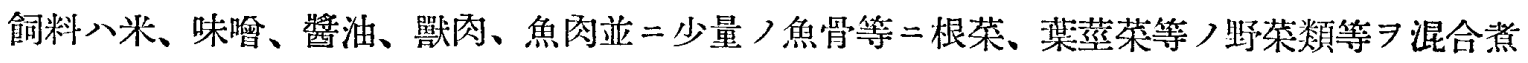

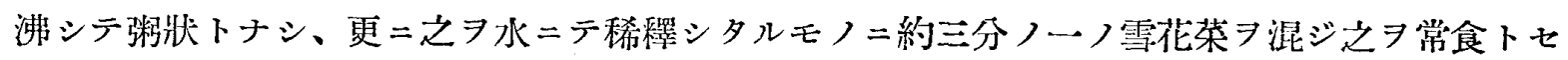
リ。

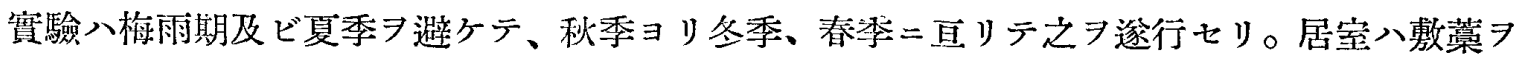
施シ、飼育場入特二清潔习旨トシ、通風探光二留意シテ努メデ運動不足二陷入ラザルヤウ意 フ注 ギタリ。實驗開始二先ダチデ更二嚴密ヨ期センガタメニ、少クトモ 3 週間內外ノ前潐備 アナ シ、環境並ニ飼料ニ馿レテ體重ノ增加ヨ來シ發育佳良ナルモノ、ミヨ準擇シテ實驗二供七リ。

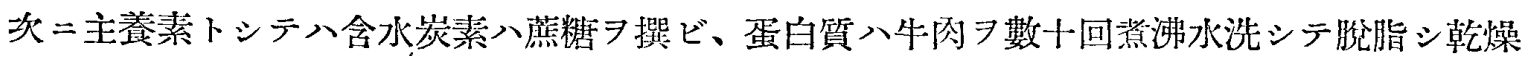
セルモノヨ用七、脂肪物質ハ「オレフ」油ヨ使用シタリ。カクシテ 40 頭內外ノ幼犬フ次ノ四群= 分チ、主養素フ相互二混合シテ常食二添加シテ偏食實驗 


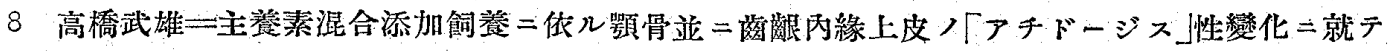

第一群 常食二「蔴糖+牛蛋白」ヨ添加ス。

第二群 常食二「牛蛋白十オレフ油」フ添加ス。

第三群 常食ニ「オレフ油十鷹糖」ヨ添加ス。

第四群 常食二「蔴糖十牛蛋白十オレフ油」ヨ添加ス。

以上ノ添加量八體重一䣶二對シテ總和五瓦ヨ標準トシ、時ニ八適磪二變化ヨ觀察センガタメ 大量ヨ與ヘシコトアリ。而シテ實驗ニ當リテハ完全二目的フ澾センガタメ、空腹時先ヅ少量ノ 常食二主食素ヨ以上ノ如ク混合シタルモノヨ涯加シ之ヨ完全二攝取シタル後、始メテ相當量， 常食习與へテ以後八自由攝取二委ネタリ。

\section{第二笁 標本製作法}

屠殺後間モナク犬ノ顎シ分離シデ通法つ如ク $10 \%$ Formalin 液ニテ固定スルコト2週間內外 トナシ、䐋灰入10\% Formalin 液ニ3万至 $5 \%$ ノ割合二硝酸液フ作リタルモノヨ賞用シ、時ニ八

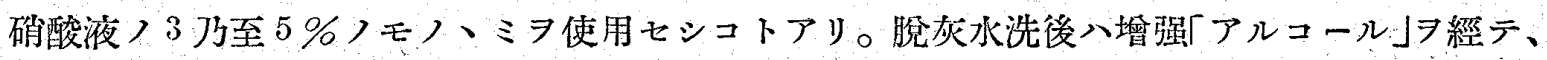
Zelloidin 包理 Haematoxylin-Eosin 複染色ヨ施シ。用二應ジテ van Giesonsche Methode ク用ヒタリ。向ホ色 素染色二ハ Haemosidesine，Perls-Stieda 氏「ベルリン」青反應法及ビ R. Schneider 氏つ變法 ヨ施シ、且ツ又 Weigert 氏繊維素染色法ヨ施セシコトアリ。

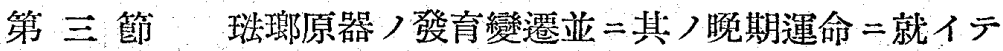

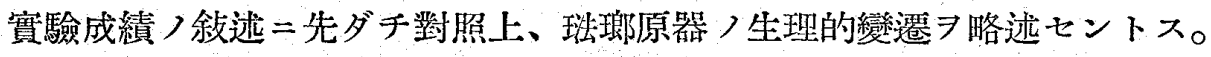

衆知ノ如ク蒛芽發育ノ第三期タル鐘形期 (Glockenstadium) =至レバ珐瑯原器ハ明カ二四首

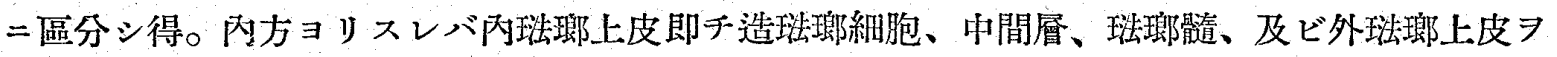
列擧シ得。

(A) 內球瑯上皮二造珠瑯細胞 (inneres Schmelzepithel, Ameloblasten, Ganoblasten) 之八名

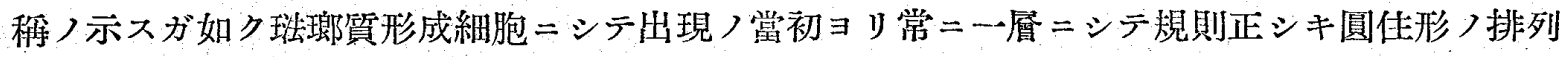

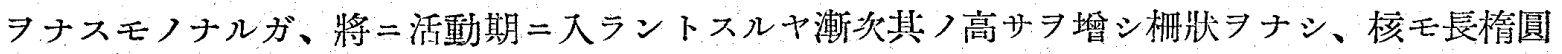

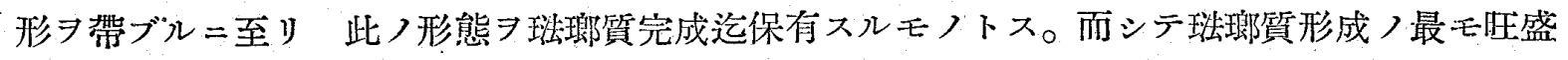
ナリト思惟スベキ時期二在リテハ其ノ原形質內二多數ノ石灰粒下見做スベキ小滴ガ時二八大小

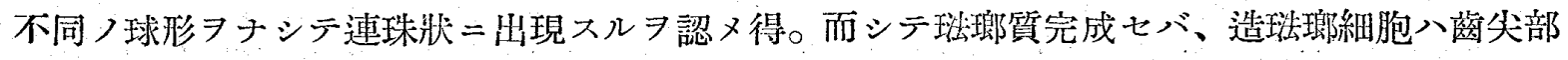
ヨリ漸次生理的二退行シテ細胞ノ高徑並二幅員ヨ減ジ、核モ pyknose トナリ トームス氏突起 モ消失シテ最早此つ期二在リテハ原形質內二八前記つ石灰槛㴝球滴八存在セザル二至ル。カク

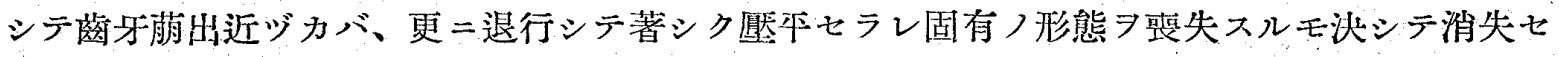
ザルガ如シ。

(B)，中閒層（Stratum intermediūm），本層八造珠瑯細胞二密接七ル細胞層ニシテ出現ノ當初 


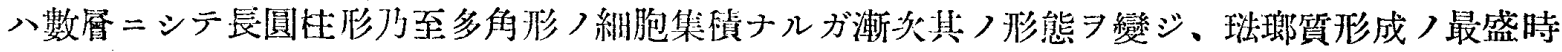

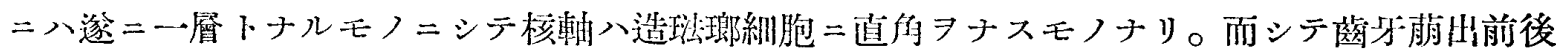
ニ八全ク消失スルモノナリ。

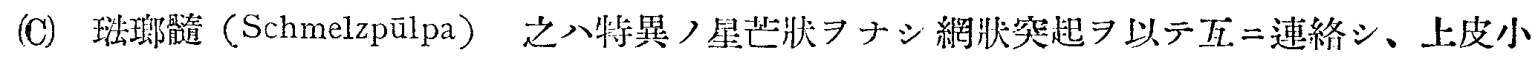

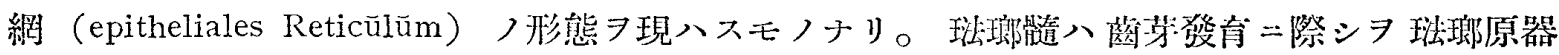

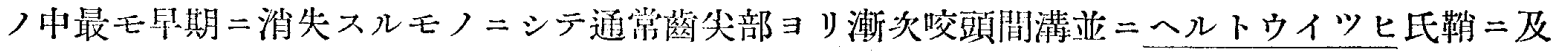
ブモノトス。

(D) 外㗀瑯上皮 (äusseres Schmelzepithel) 本上皮八多角形或八圓形二近キ扁本細胞ニシテ

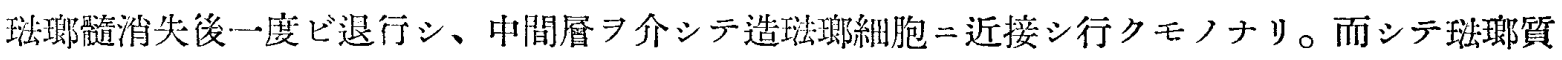

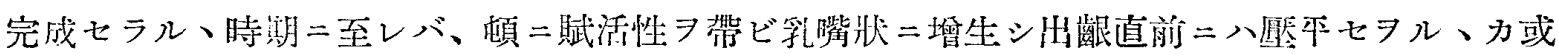
八增生〉睢、全ク偏本上皮ノ形態习探ル二至ル。

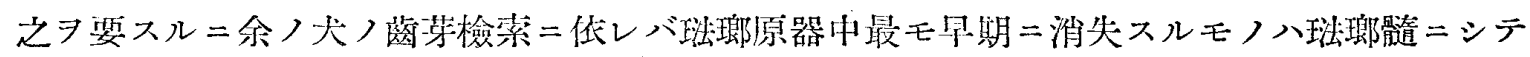

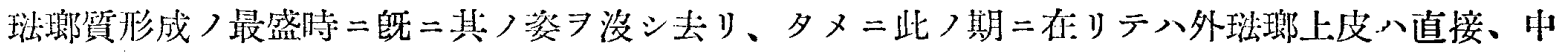

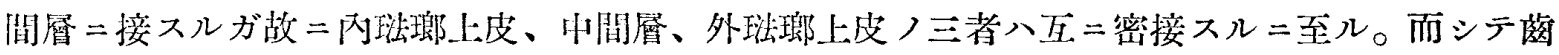

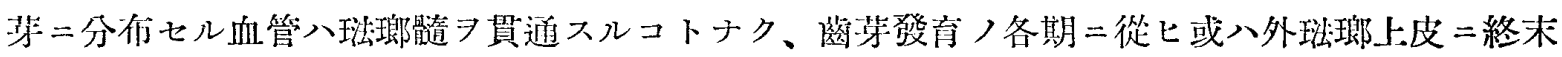

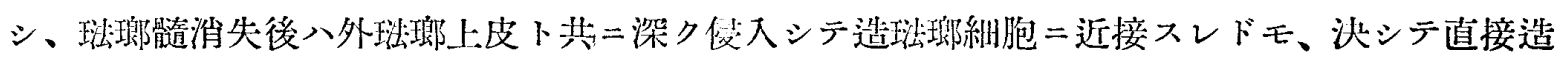
琌瑯紏胞層中へ分布セザルモノナリ。

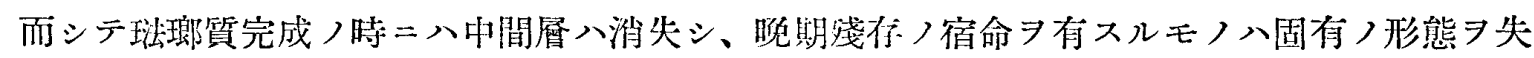

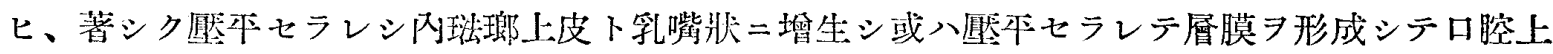
皮ノ形態ヨ探レル外㨏瑯上皮ノ二者ノミニシテ、此ノ网者入全ク區別シ能ハザル迄二密接シテ

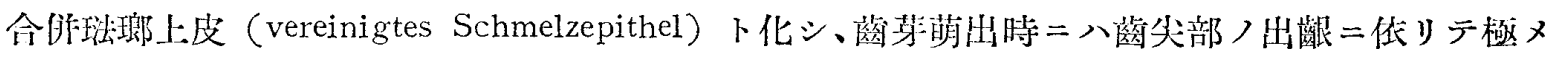

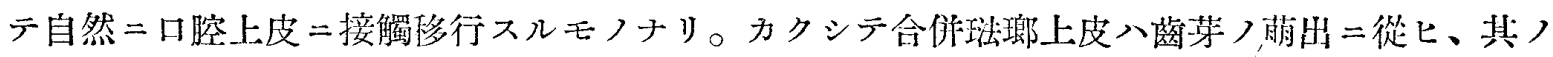

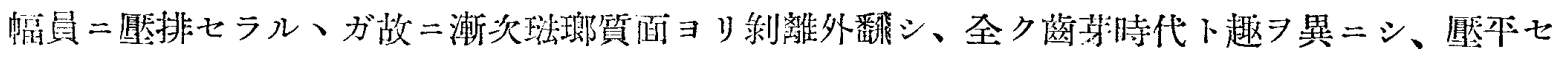

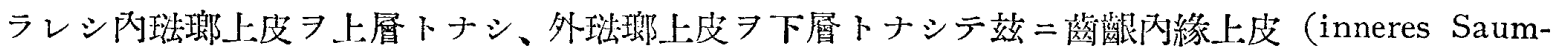

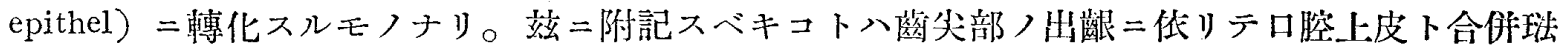

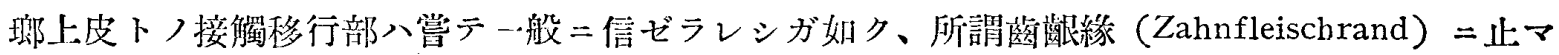

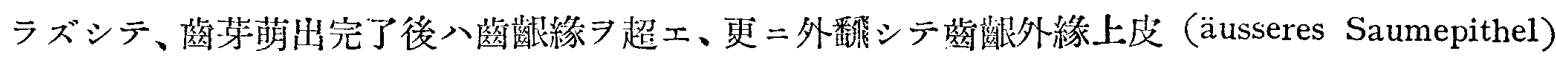

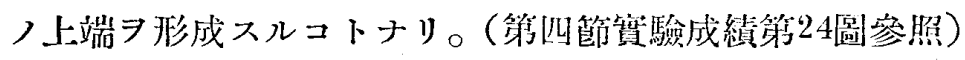

以上ノ機垍习圖示スレバ次ノ如シ。(未脫灰模型圖) 
（1）外法瑯上皮八乳媘狀二增生中

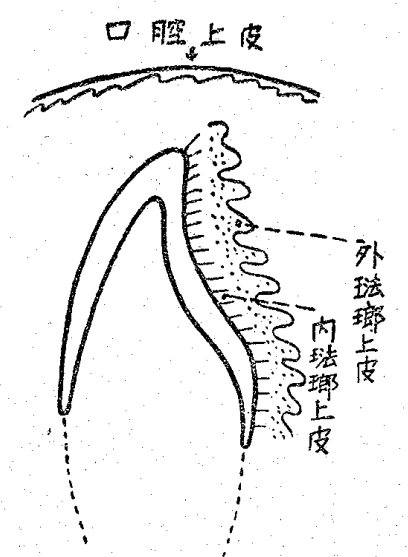

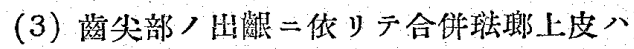
口腔上皮卜接觸移行

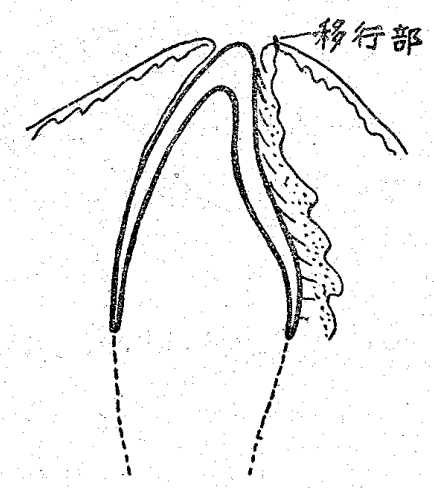

(5) 合伴珐睓上皮卜口腔上皮了移行部八更

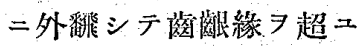

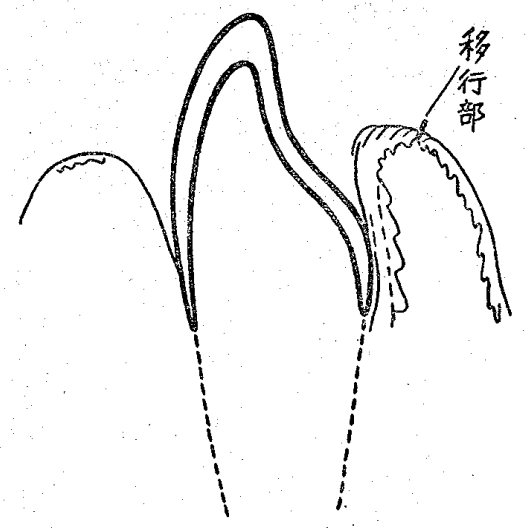

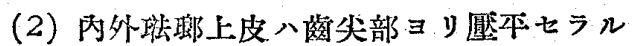

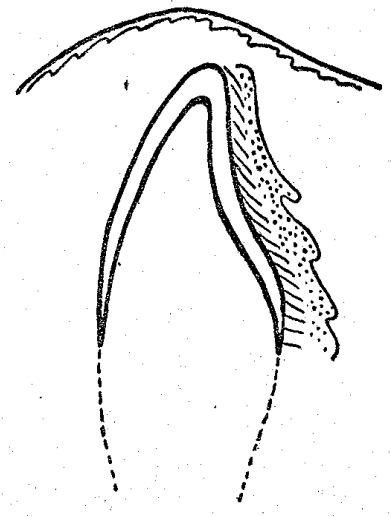

（4）合併珪璬上皮八珐瑯質面 $コ$ リ剩離 外翻

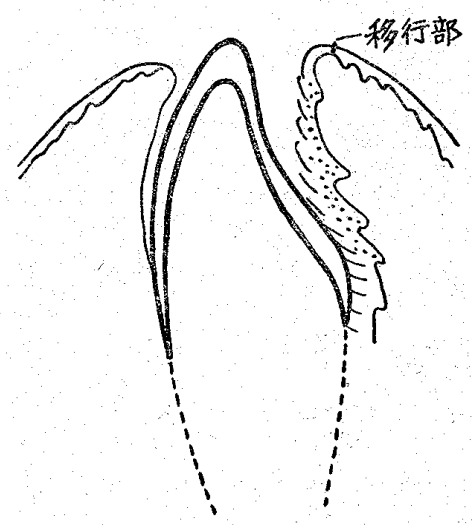

(6) カタシテ厴本七ラレシ内珠理上皮

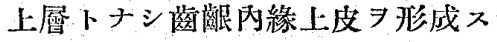

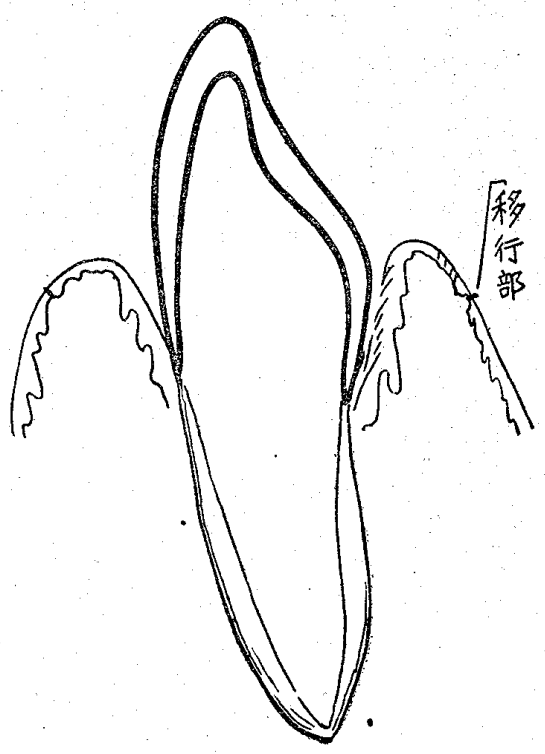




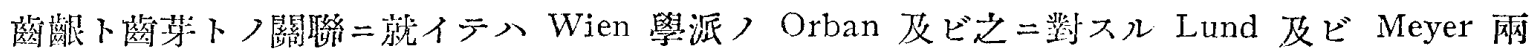
㚤ノ見解习紹介スレバ次ノ如シ。

(A) Orban

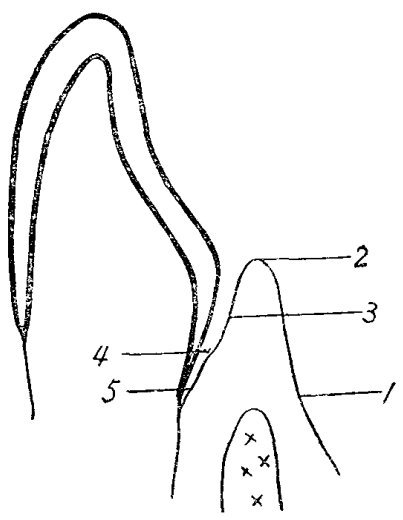

A) Orban

1. Mundepithel二日腔_L. 皮

2. Zahnfleischrand=落推綵

3. Taschenepithel二盲装上皮

4. Taschenboden二-盲翟底

5. Epithelansatz=上皮附旗部
(B) Lund 及ビ Meyer

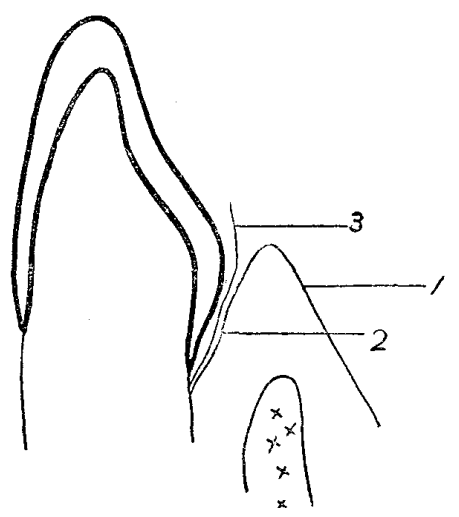

B) Lund 及ビ Meyer

(1) äusseres Sanmepihel二曼裉外緣上:皮

(2) inneres Saumepithel二茲裉內緗上皮

(3) Schmelzoberhäutchen=琣恼質表面薄膜

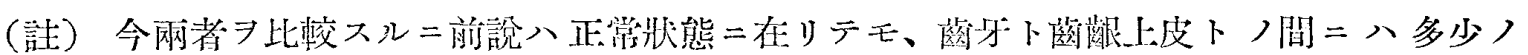

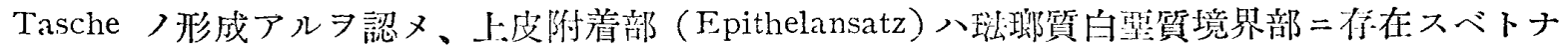

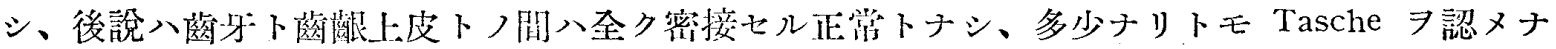
バ之ヨ病的状態ナリトノ見解习持セリ。

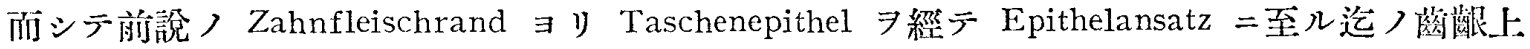
皮ハ、後說, inneres Saumepithel ニ一致シ、 äusseres Saumepithel 八前說ノ Muudepithel = 該當スルモノナリ。

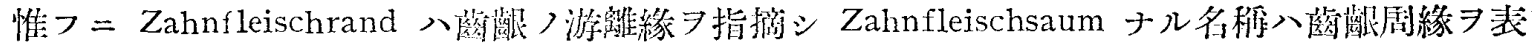

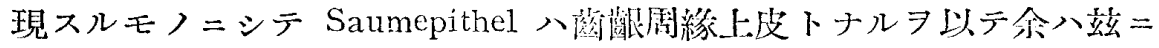

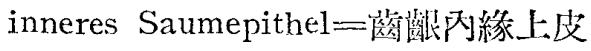

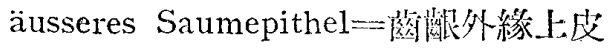

ナル邦語习以テ畄テントス。

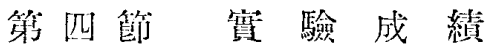

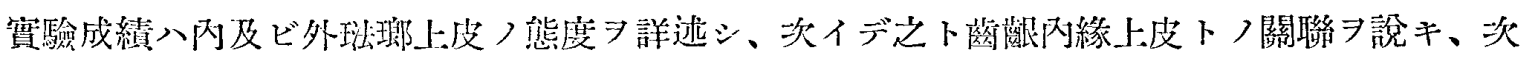

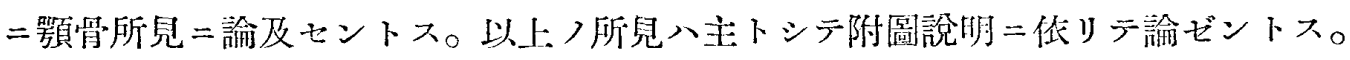

（註）犬ノ永久珤式八 


$$
\mathrm{I} \frac{3}{3} \mathrm{C} \frac{1}{1} \operatorname{PM} \frac{4}{4} \quad \mathrm{M} \frac{2}{3}=42=シ テ
$$

萬國記標數字: =低レバ

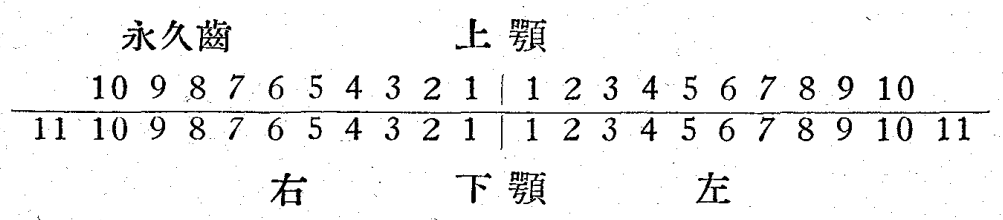

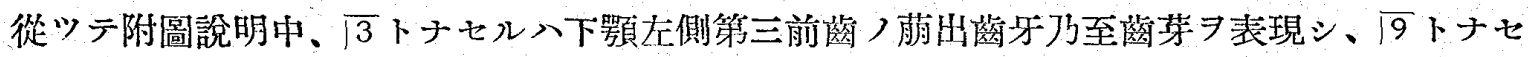

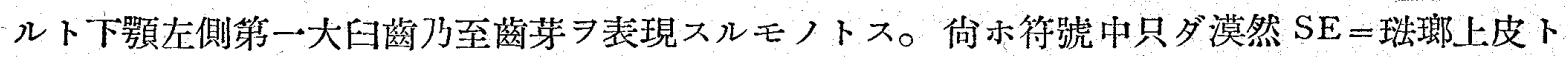

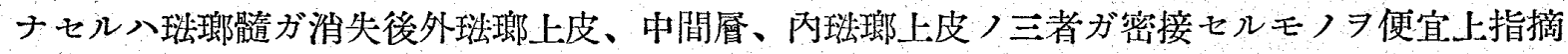

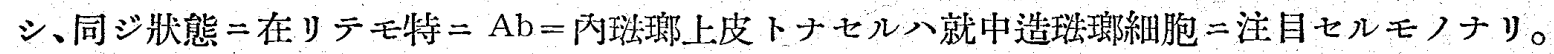

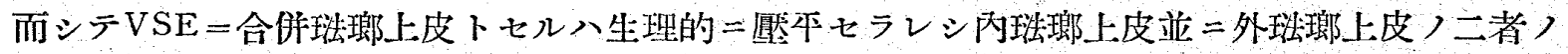

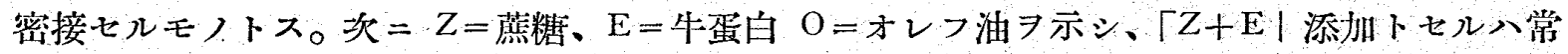
食 $=$ 「蕉粮十牛蛋白」ヨ添加意味スルモノトシ、以下之二準ズ。

次二附鲾略號八便宜上次ノ如クセリ。
$\mathrm{Ab}=$ 造昢珢細胞（队現瑯上皮）
$\mathrm{AD}=$ 理瑯質瘤
$\mathrm{ASE}=$ 外泆瑯上皮

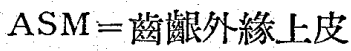
$\mathrm{BL}=$ 出血箵
$\mathrm{Bg}=$ 結締織
$\mathrm{D}=$ 象牙質
$\mathrm{DA}=$ 退行セル造珐瑯細胞
$\mathrm{DO}=$ 退行七儿造䔄細胞
$\mathrm{E}=$ 滲出血百至分泌物
$\mathrm{EA}=$ 上皮附着部
$E R=$ 上皮闪鎼裂
$\mathrm{F}=$ 裂溝
$\mathrm{Fb}=$ 緎維素
$\mathrm{G}=$ 血管
$\mathrm{H}=$ 毛髮
$\mathrm{HS}=$ ヘルトウイツ氏氏鞘

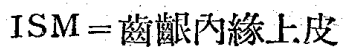

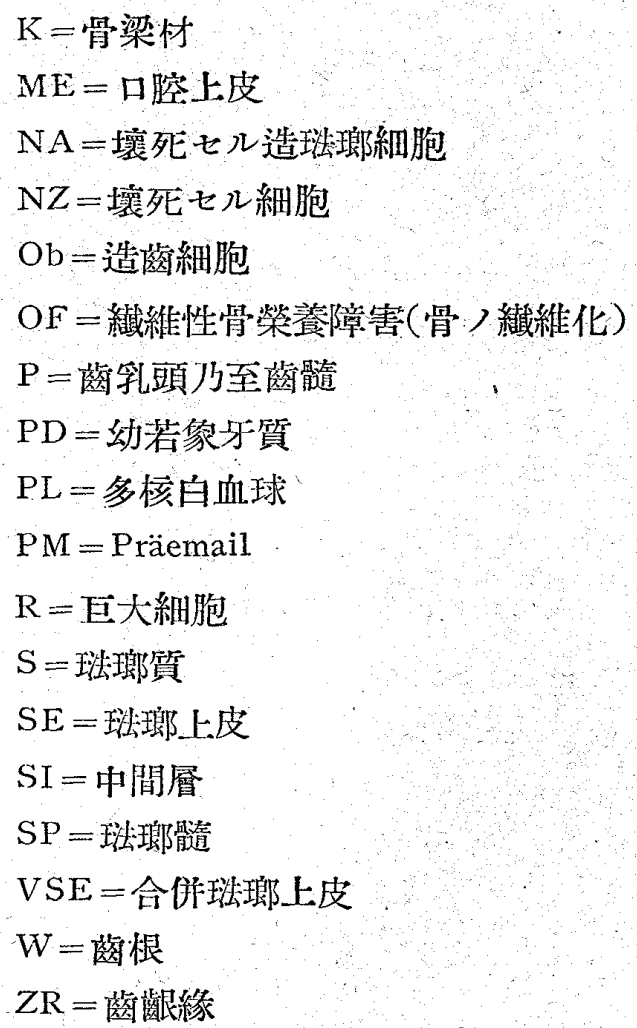




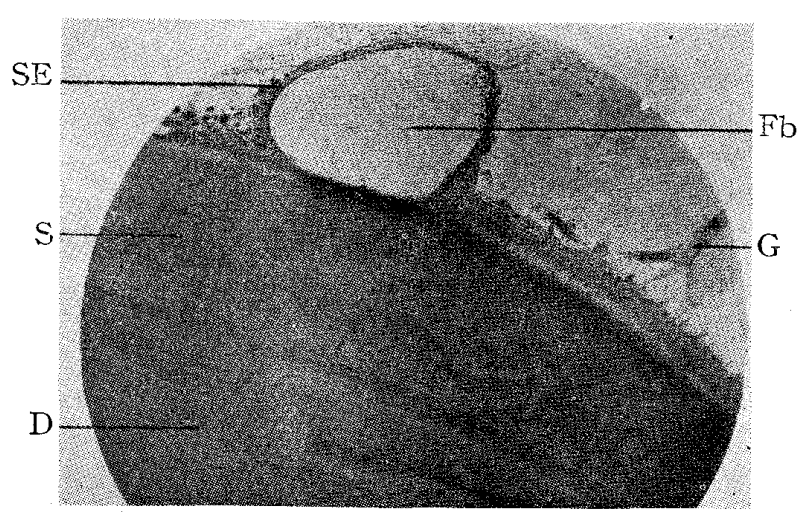

\section{管 一 圖}

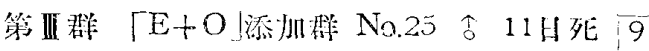

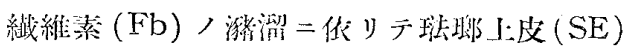

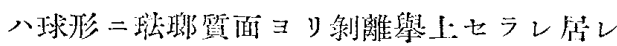
リ

\section{管 二 圖}

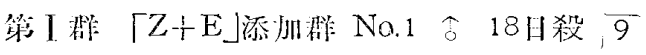

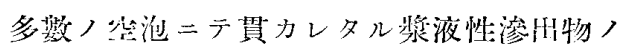

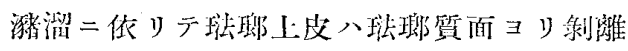

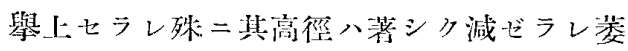
維シ $(\mathrm{DA})$ 一部八全》離憉脫落七り $\left(\mathrm{DA}_{2}\right)$

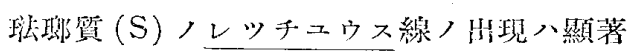
ナリ

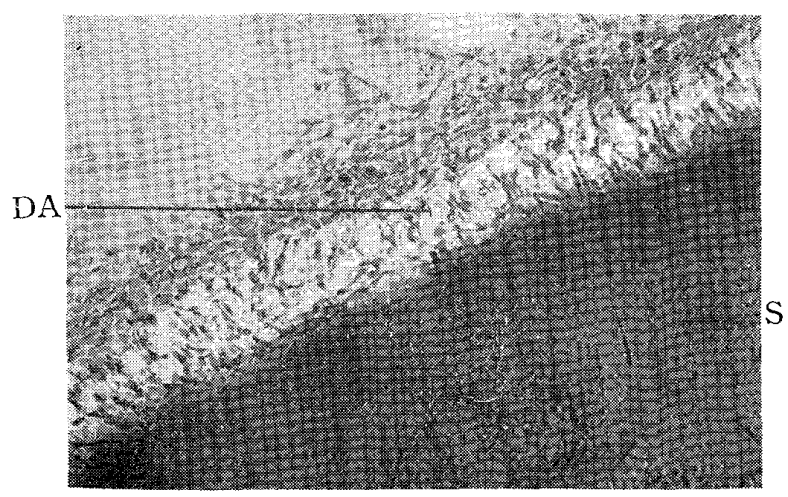

第三圖

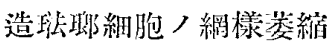

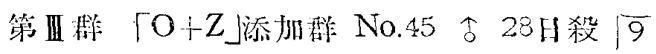

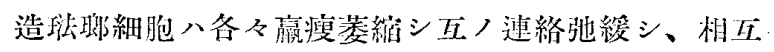
閒二些泡 $\exists$ 形成

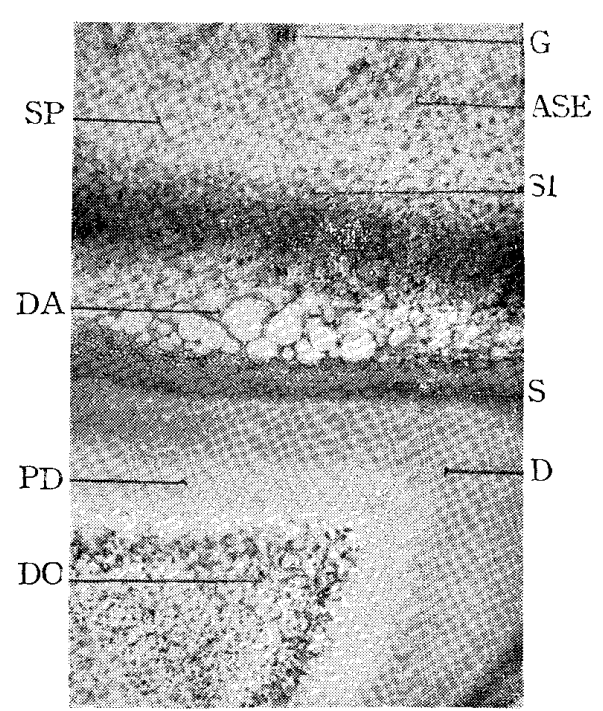

\section{第 四圖}

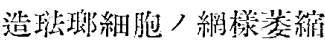

第政礁「O+Z」添加整 No.4 우 18 日死 $\overline{3}$

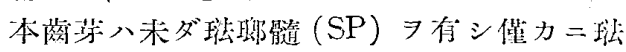

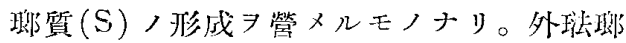
上皮 $(A S E)$ 二八多教〉血管 $(\mathrm{G})$ 茂生シ、小

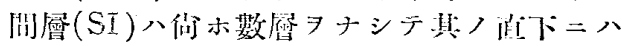

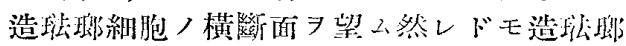
細胞八还行シテ多教ノ空泡ヨ形成シ全ク絧

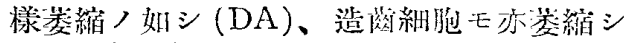
居レリ(DO) 


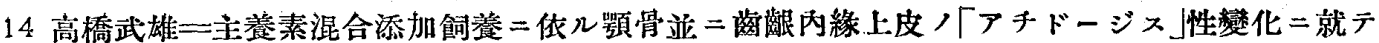
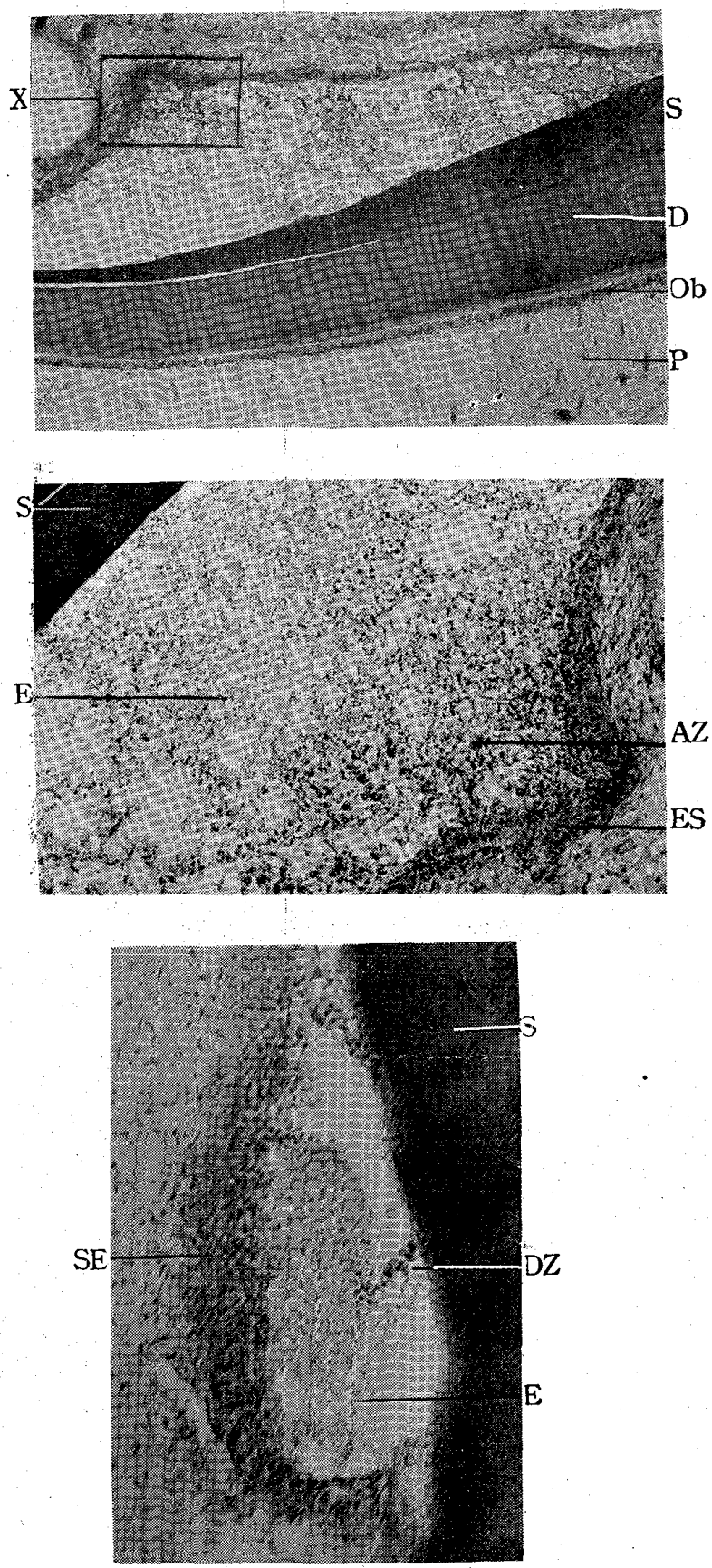

第七圆

第 II 群 $\Gamma \mathrm{E}+\mathrm{O}$ 」添加群 No.21 우35日殺

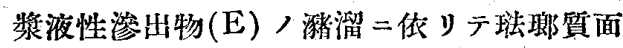
ヨリ孤狀二剩離七ラレタル斑瑯上:皮 $(\mathrm{SE})$ 八二次的二退行シ球形 來シテ原形質ノミトナリ、恰モ出血鼠/如 手觀ヨ是シ居レリ $(\mathrm{DZ})$

\section{第 五圆}

第 IV 群 $\lceil Z+E+O$ 筷加群 No.63 合 19 日死 $\longdiv { 9 }$

\section{第 六 圖}

前圖X部ノ强援大，造斑瑯細胞ノ滴狀萎縮 エオジン好染，分泌物 $(\mathrm{E})$, 㴯溜二依り珪瑯 質面ヨリ廣ク制離舉上七ラレタル珐瑯上皮 (SE) 殊=內珐珢上皮八二次的二變性等縮シ テ球形ヨナシ空隙中人脱落ス (ZA) 此ノ時細 胞ハ先ジ屑形トナリ核モ姜縮シ次イデ核ノ消 失 7 來シテ原形質ノミノ球滴トナリ一見血竅 ノ如手觀 呈スルモノナリ

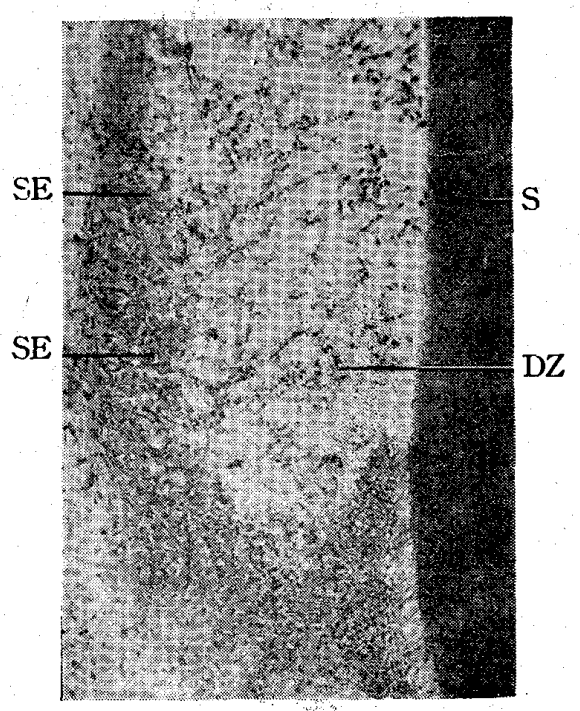

第 八圆

第群「E+O」添加群 No.21 우 35 日殺 19 剝離擧上七ラレタル琌瑯上皮 (SE) や、特

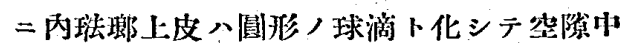
一脢落ス 


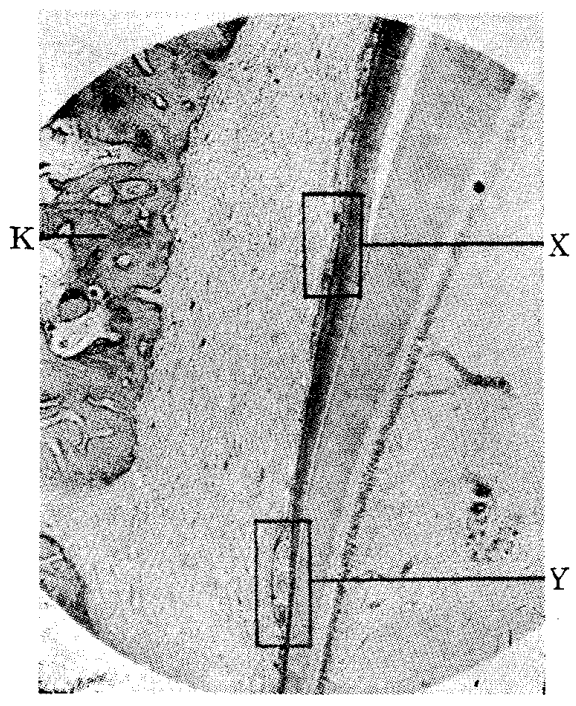

第 九 圖

第 II 碓「E+O」添加推 No.22 우18日殺 9

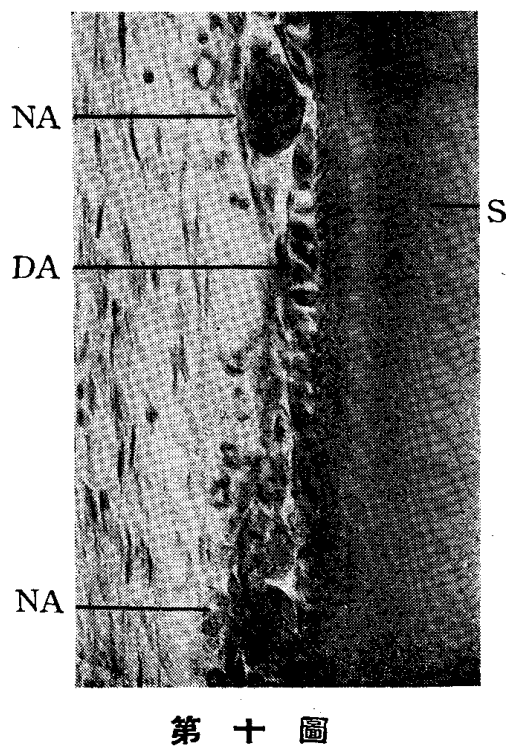

前圆 $\mathrm{X}$ 部ノ擴大 造珐激細胞ノ壊死 7 示ス。 落芽八旺盛ナ゙ル發育期二際會セル二拘ラズ、造琣唧 細胞八萎縮退行シ (DA) 或八原形質八强度二腄脹 テ核モ亦崩塄シ (Karyolysis) 壊死二陷り、恰カモF。 大細胞ノ如手觀 9 呈シ居レリ(NA)。

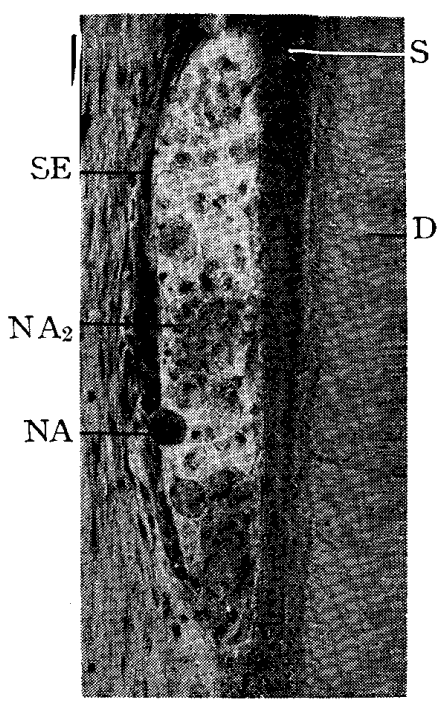

第 十 一 圖

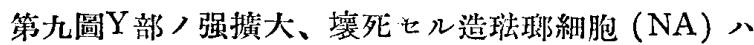
踒落シテ隣在上皮 7 㦛上セシメ $(\mathrm{SE}) 、$ 終リニ八原形 質, 融解 $\exists$ 來ス二至ル $\left(\mathrm{NA}_{2}\right)$ 。

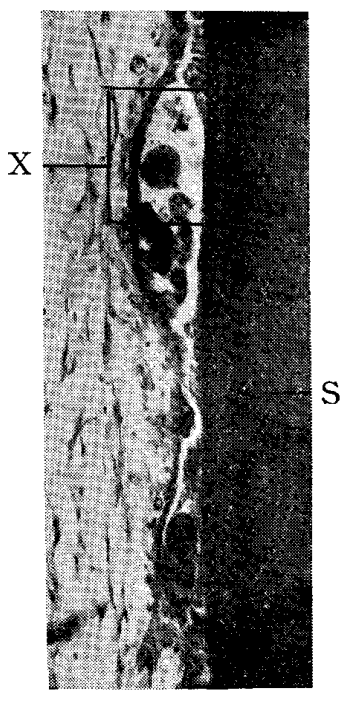

第 + 二圖

第 I释 $\lceil\mathrm{E}+\mathrm{O}$.添加群 No.22 우 18 日秘 


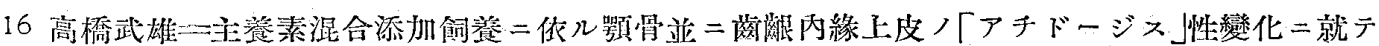

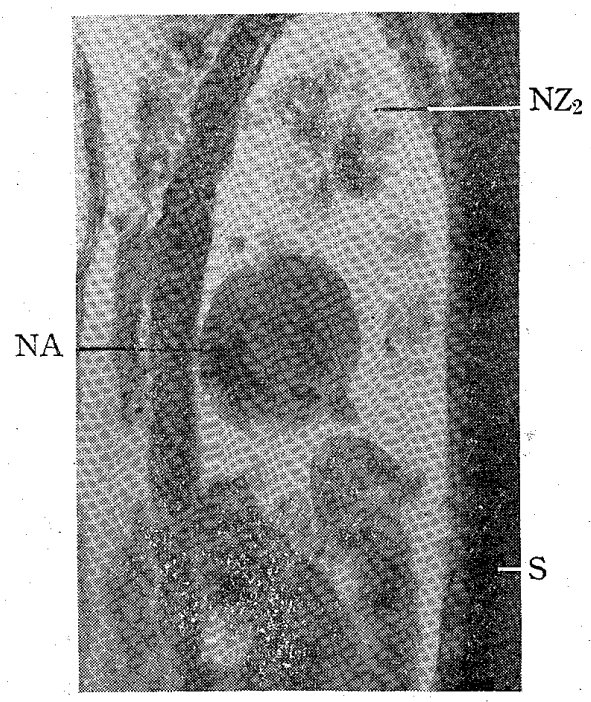

第十三圖

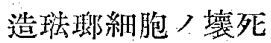

前圖X部ノ强擴大、

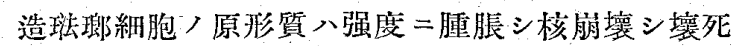
$(\mathrm{NA})=$ 陷り、次イデ原形質八融解シ居レッ $\left(\mathrm{NZ}_{2}\right)$

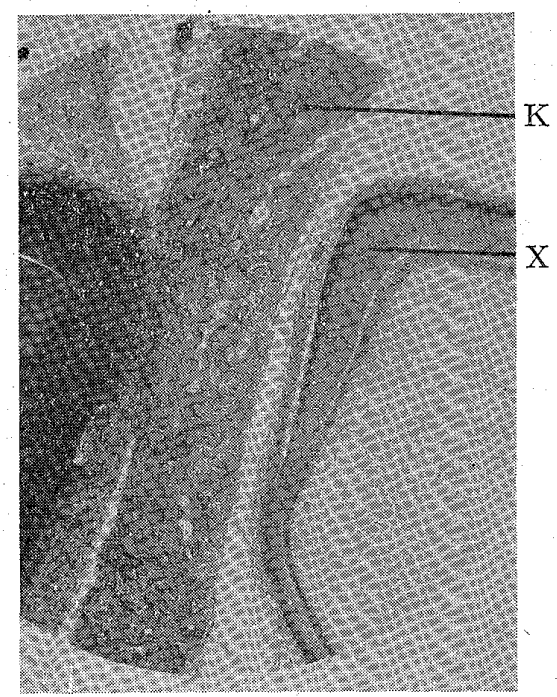

第十四圆

第吕群 $\Gamma \mathrm{O}+\mathrm{Z}$ 」添加碓

No. 42 占 35 日殺 9

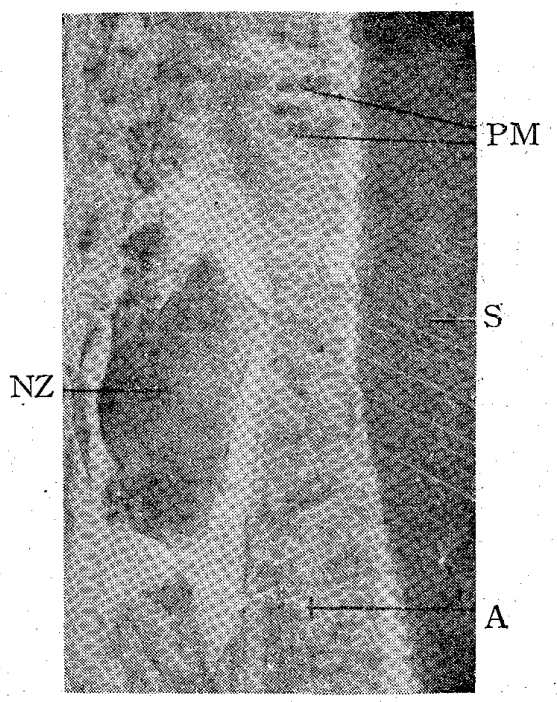

第十五圖

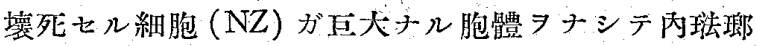

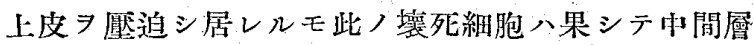
ナリヤ否ヤ頗ル疑問ナリシ ツ以テ連續切片 及シタリ。次圖习見 $\exists$ 。

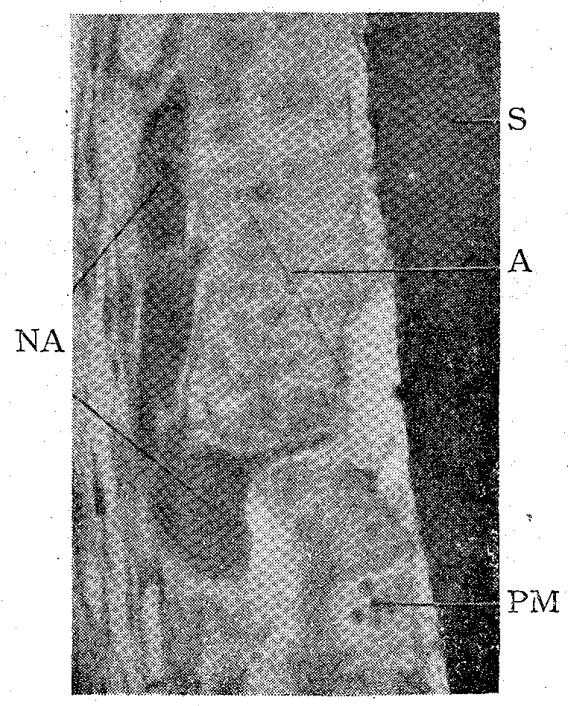

第十六圖

第十五圖ノ連續切片二於テ八、藵死細胞八中間曆二 非ズシテ造斑瑯細胞ガE大ナル胞體ヨナシテ「アメ ーバー」狀ヨ是シテ外方二㧤出セントセルモノナル ヨ知レリ。(NA) 況ンヤ、其ノ左方二八生理的二退

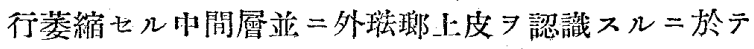
$\Rightarrow+$ 。 


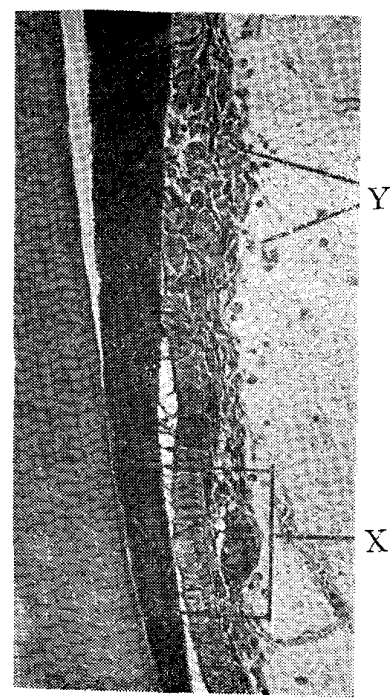

第十七鳀

第 II 群「E+O」添加㴋

No.21 ? 35 日殺

法㒋上皮ハY部二於テ著シク雜然タルモノアリ。

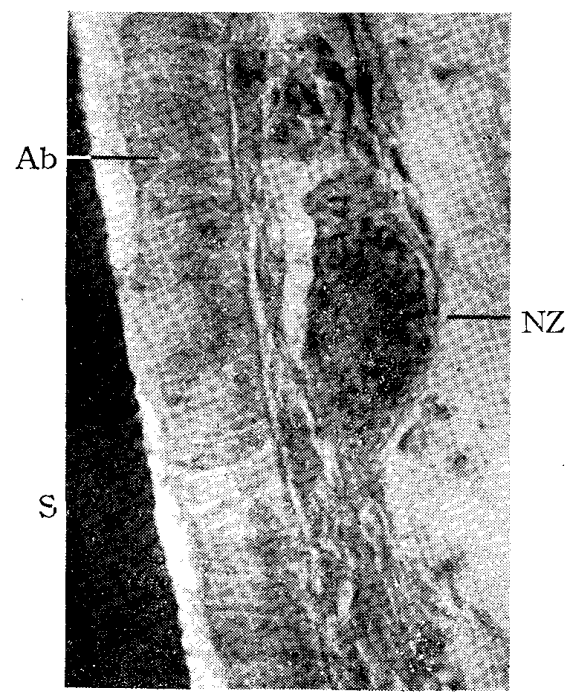

第 $+八$ 圆

前阔 X部ノ强剑大、

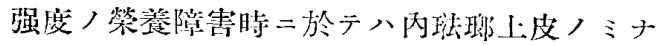
フズ、外站砸上皮モ亦、原形犋蕾脤シ、核モ 亦崩燷シ、壊死二陷レルコトアリ $(\mathrm{NZ})$ 。

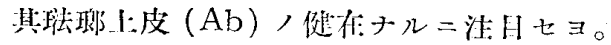

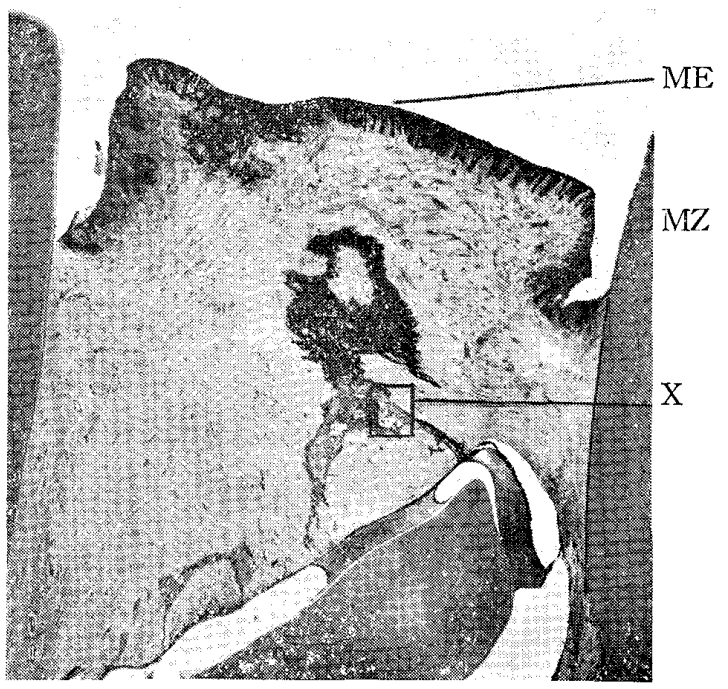

第十九圖

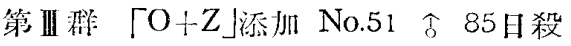

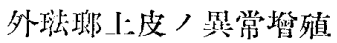

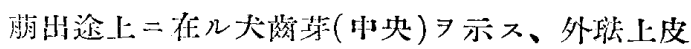

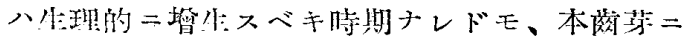

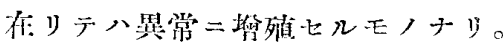

$\mathrm{MZ}=$ 乳大业

更二次闹户是ヨ。

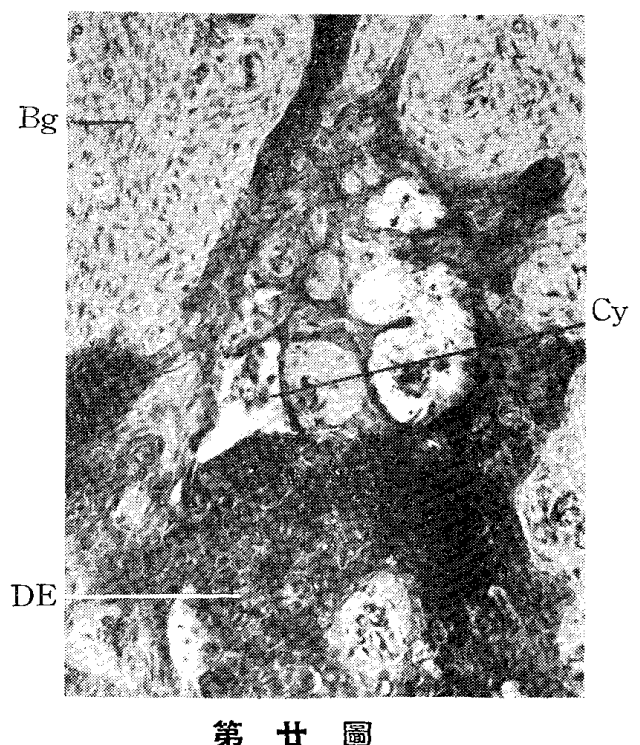

前阔X 部ノ强接大、

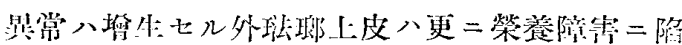
リ、原形質阫脤セルモノアリ $(\mathrm{DE})$ 更二非ンデ

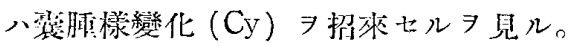




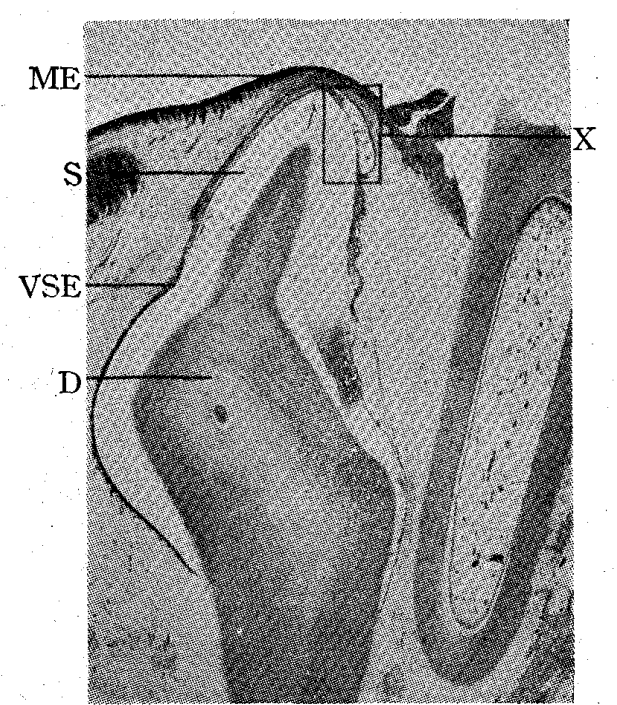

第 $=+$ 一 圖

第III澼 $\cdot \Gamma \mathrm{O}+Z$ J添加群

No.47 合 78日死 $\overline{4}$

今將二出滴セントスル犬闵芽ニシテ落シク口腔

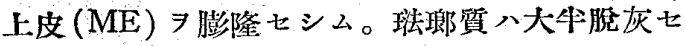
ラレ、珐瑯上皮八合僧珐瑯上皮(VSE) >形態 7 探レリ。最モ注目スベキハ齿尖部右方二囊腫樣 變化ノ存在スルコトナリ(X部)。

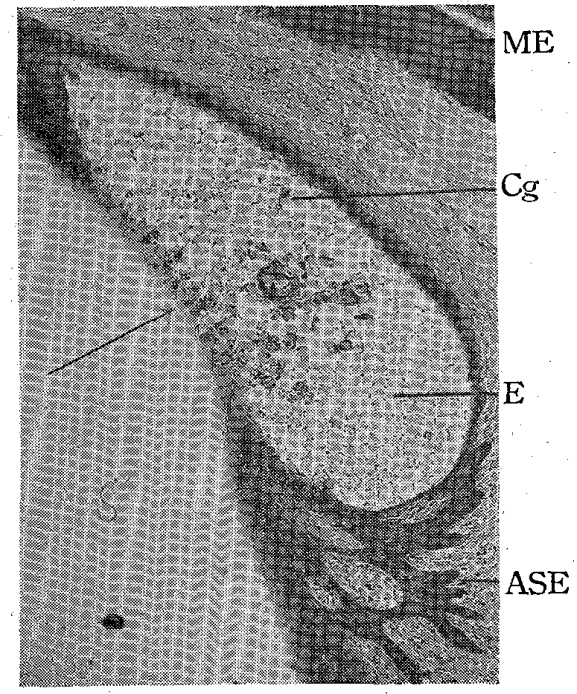

$$
\text { 第 }
$$

前圖X 部ノ强顀大

囊隀樣變化ノ內容物八「ェオジン」好染ノ細滴 卜、珐瑯上皮細胞, 賋死物質 $=シ$ テ、特 $=\uparrow$ 印部二於テ珐瑯上皮ノ脢落シッ、アルラ目擊 シ得ルナリ。

（份木第六圖、第七圖、第八圖习參照ノコト）

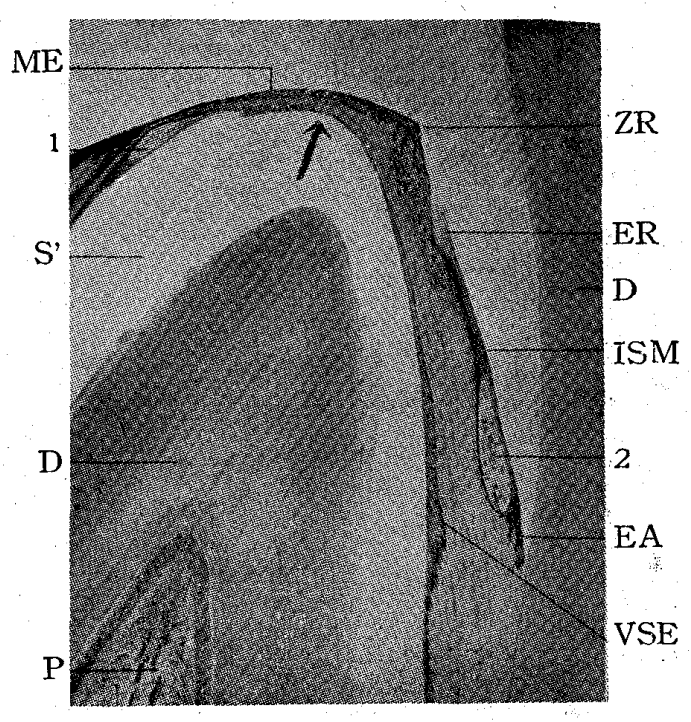

第二十三圖

第III礁 $\lceil\mathrm{O}+\mathrm{Z}$ 添加群 No.47 合78日死

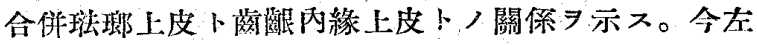
方ノ犬䠃芽が 印部二於テ萠出路 7 開拓シタリトセ ン力齿尖部，合併珪瑯上皮八口腔上皮二接觸移行シ 其ノ移行部八蔺芽萠出二從七其, 幅員二壓排セラ几

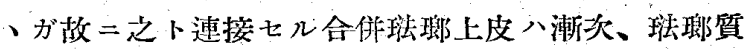

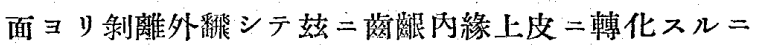

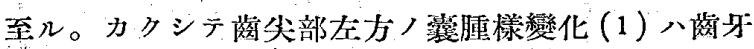

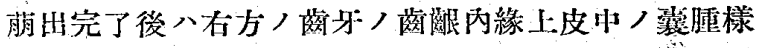

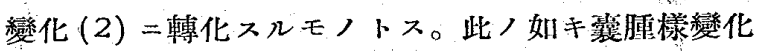
八內容物八前圖卜同漛二「エオヂン」好染ノ細滴卜變 性二陷レル上皮細胞ナリ。 


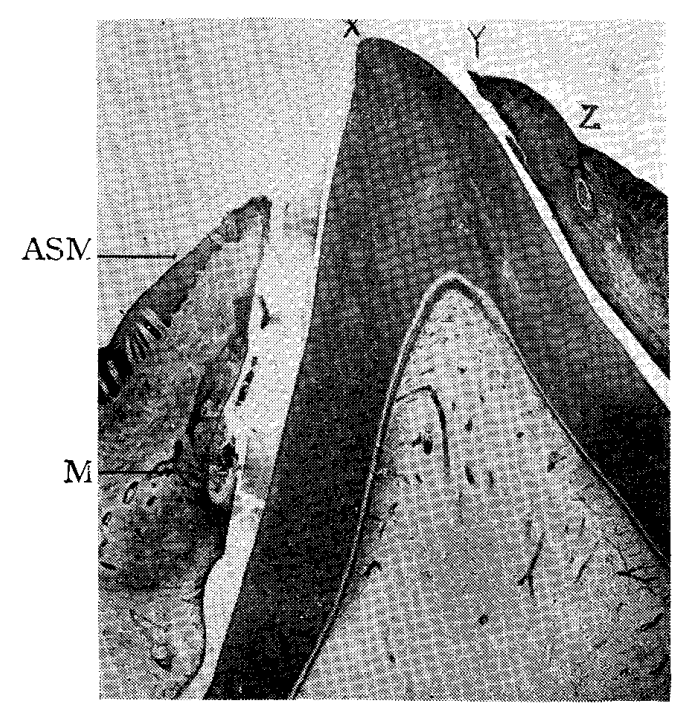

第二十四圖

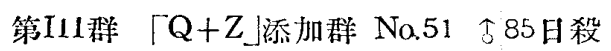
苳身: 萠出時二於ろ几所見。

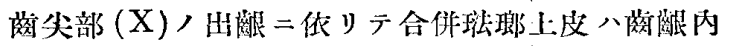
緣上皮二轉化シッ、アリ、左方ノ合㴊法躯_L皮小 二八病的組織ノ發生 7 見儿。特二注目スぶキ八落 尖部右方 $(Z)$ 部 $=$ 於テ上皮ノ乳頭狀ノ渮的組織

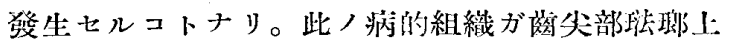
皮ノ轉化物ナル八 $(\mathrm{YZ})$ 八距離が $(\mathrm{XY})$ ノ距離二相 當スルコトニ依ツテ想像习部サルベキナリ。更二 次圖 7 見 $\exists$ 。

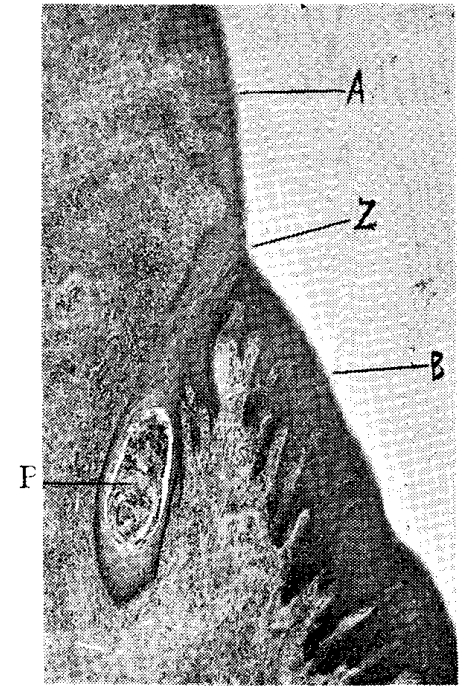

$$
\text { 第二士五圖 }
$$

前略 $(Z)$ 部 $/$ 强摭大

(Z) 部ノ乳頭狀上皮八其ノ中央部二於テ上皮細胞

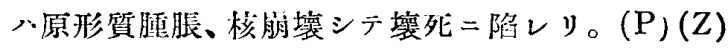
部ヨ中心トシテ上方ノ上皮(A)下下方ノ上皮 (B)

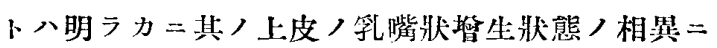
依ツテ鑑別シ得ラル。然カモ余ノ檢索二依レバ榮

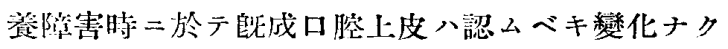
琣瑯上皮八颇儿感受性强手事實习併セ考フレバ、 此ノ病的組織 (P)八站畉上皮ノ轉化物タルコトタ 是認シ得ベジ。

前揭第二十一、第二十二、第二十三、第二十四、第二十五圖／各圖＝依りテ珪瑯上皮中二發

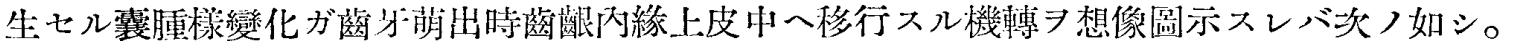

(1)

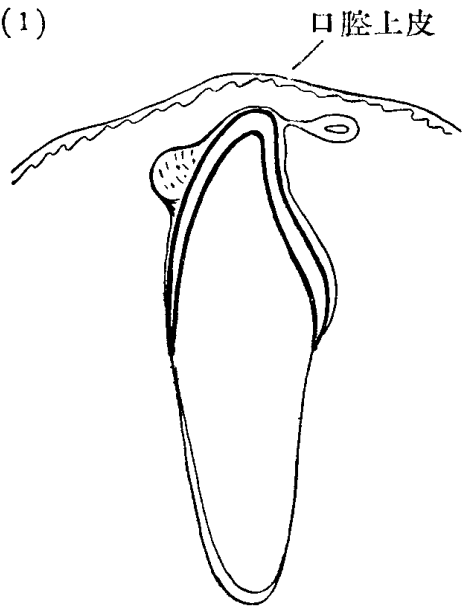

(2)

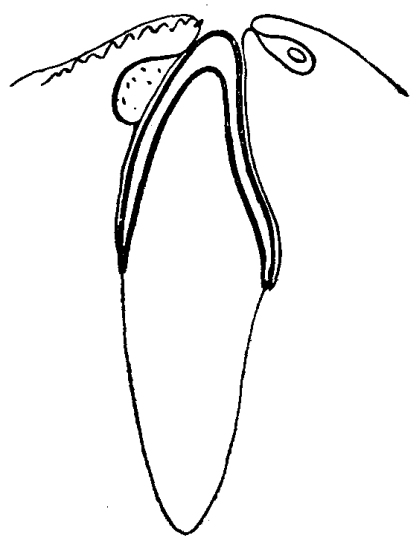

(3)

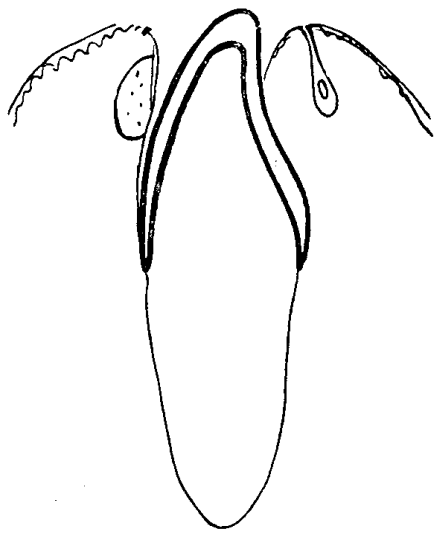


(4)

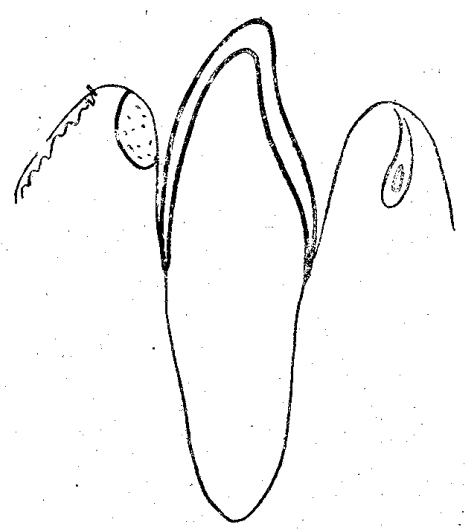

(5)

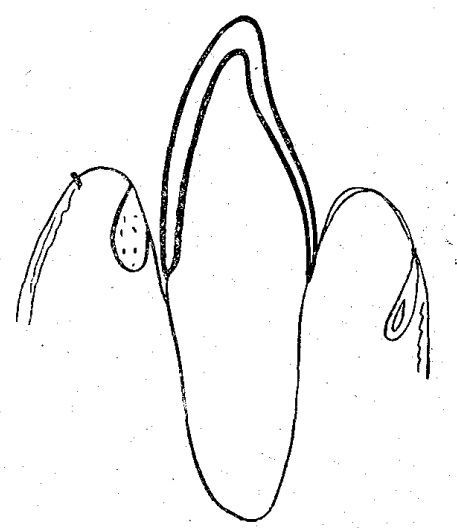

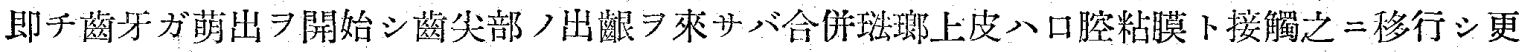

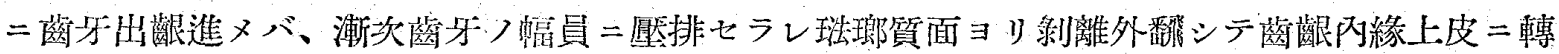

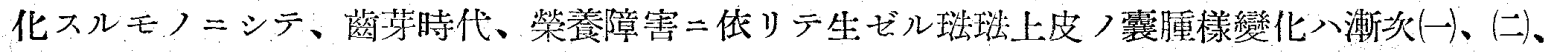

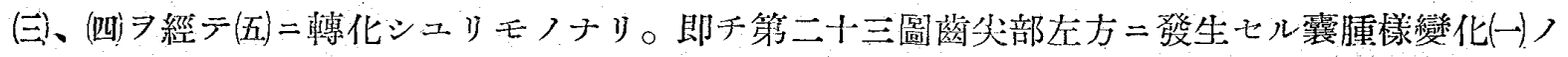

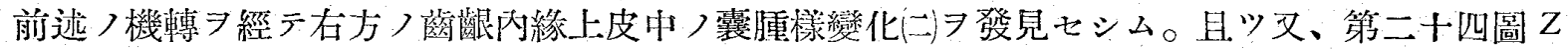

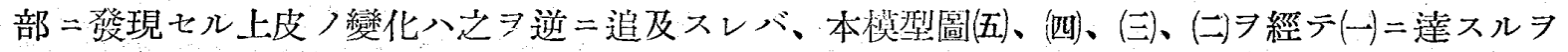
得ベク、齒芽時代ノ產物タルラ認メ得ベシ、

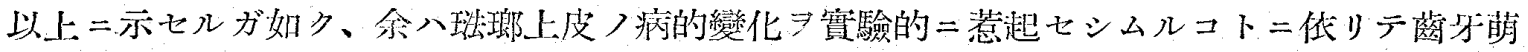

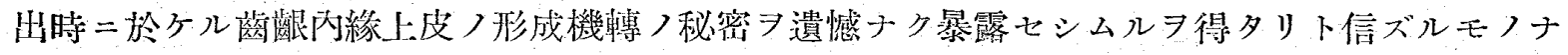
yo

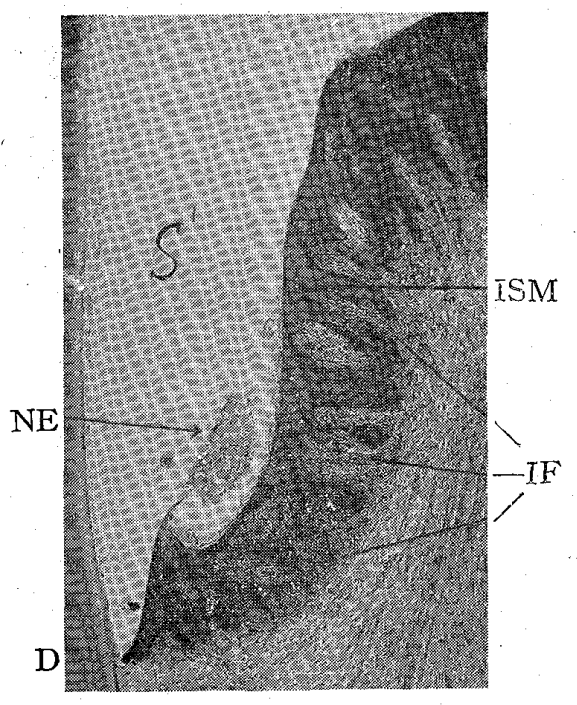

\section{第甘六圖}

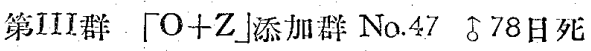

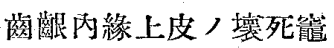

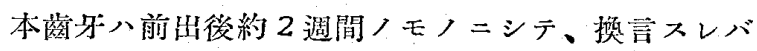

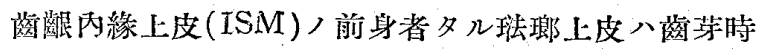

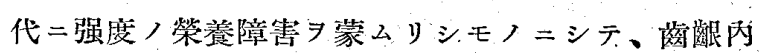

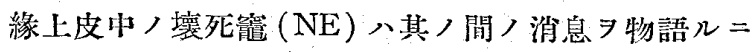
足ルモノナリ。

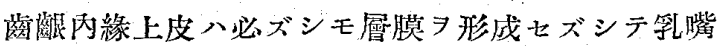

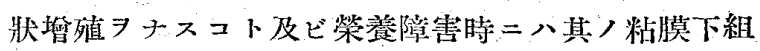
織二八細胞浸潤 (IF) 八存在スルコトハ看過ス可ラ ザルモノトス。 

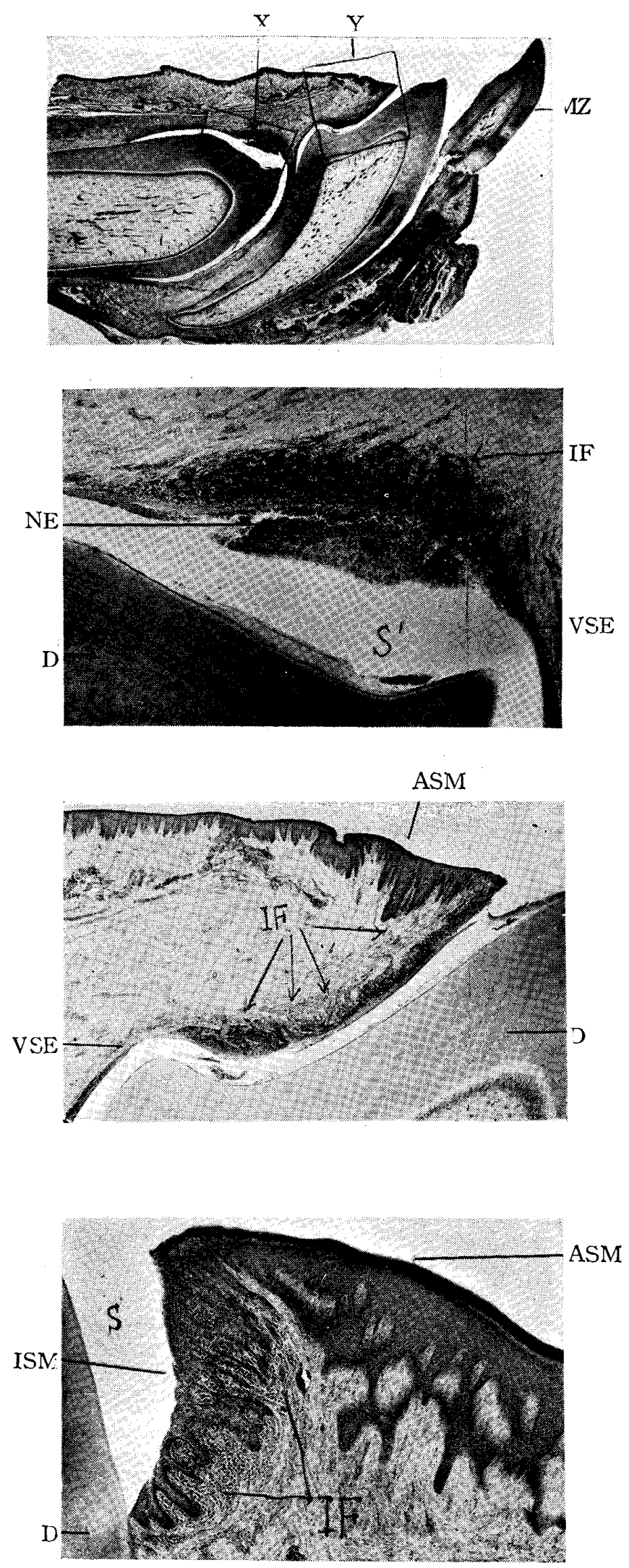

\section{第甘七圖}

第III群 $(O+Z$ 」添加群 No.47 合 78日死 蓞牙交换時ノ所見 $M Z$ 八將二脱落セントスル 乳前落ニシテ、其ノ後有八僅カニ菻尖部ノ萠 出ヨ見ルニ過ギズ、其ノ後方八未ダ萠出セザ ル炵芽ナリ。

\section{第廿八圖}

前圖X部ノ捡大

菻芽時代ノ細胞浸潤习示ス。

榮養障害ノ結果生ゼ兀合併斑㑢上皮(VSE)

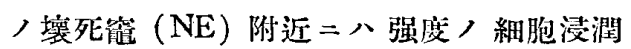
(IF) 7 認メラル。主トシテ多核白血球ノ浸 潤ナリ。

\section{第廿九圖}

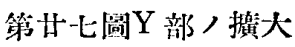

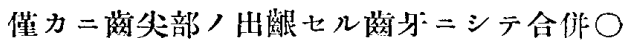
O上皮(VSE) 八將二営略內緣上皮二轉化セ ントス。站二特二注目スぶキ八策養障㫪時 二於テハ末ダ外伤用七ザル二先ダチ合

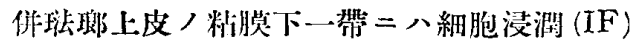
(主トシテ多核白血球ノ浸潤) 7 認メラル、

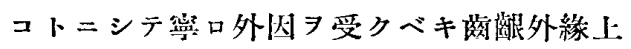
皮 (ASM) 即千口腔上皮ノ粘膜下組縕八何 等ノ細胞浸潤ナ手二注目セヨ。

\section{第三士圖}

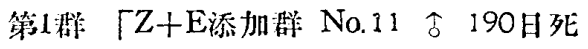

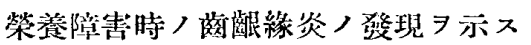
(gingivitis marginalis)

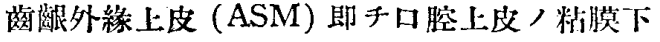

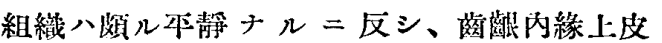
$(\mathrm{ISM})$ 人粘膜下組織八强度人細胞浸潤 (IF) 7 有シ、併七テ上皮乳頙間 テ先血怒誩シ居レリ。 


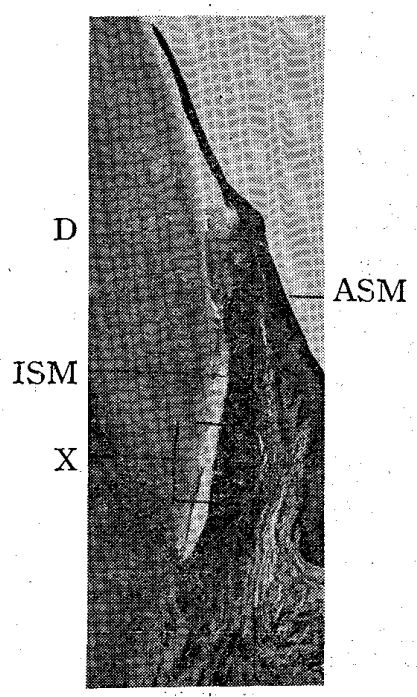

第三士一圖

第II群「E+O」添加群 No.26.含 178 日殺 同ジク策養障害時二於ケル离桹緣炎 (gingivitis marginalis) 〉發生 $\exists$ 示入。

本動物八落牙萠出前約 4 ケ月偏食實驗

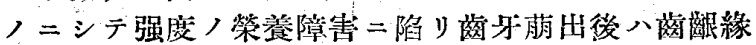
一帶三發赤 $ヨ$ 認メラレタリ。茼怅外緣上皮 $(\mathrm{ASM})$

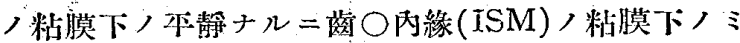
强度ノ細胞浸潤

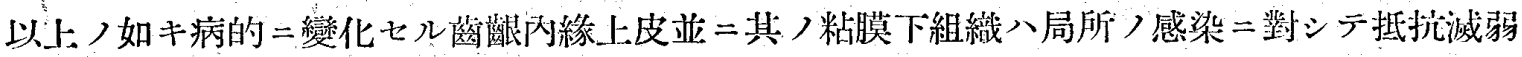
部タリ得ルハ容易二想像セラル、所ナリ。

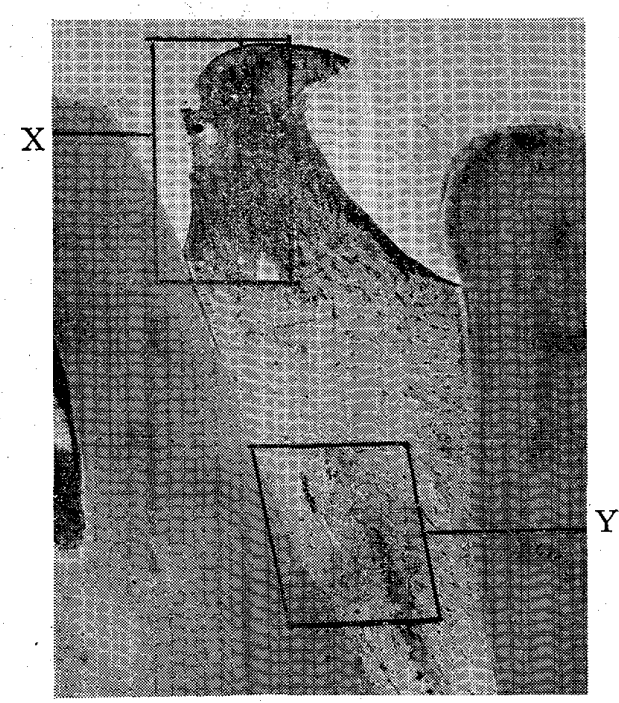

第三士三圆

第巧群 「E+O 添加群

No.31 令 195 日殺

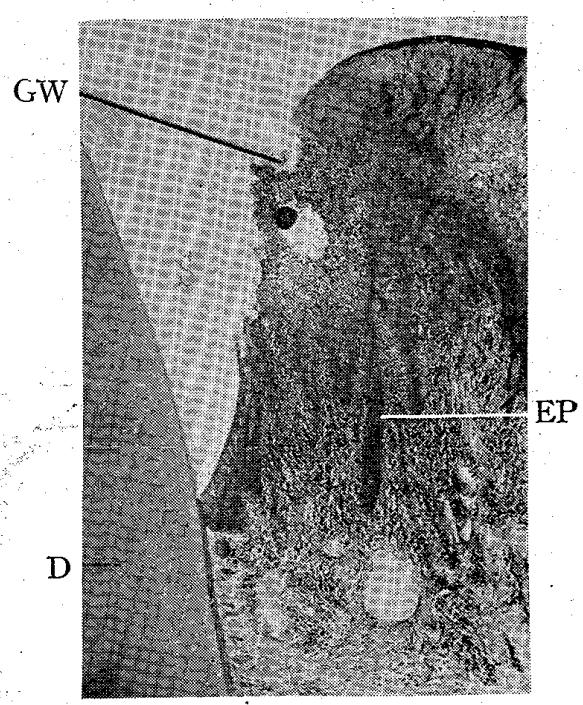

第三十四圖

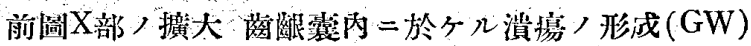
ヨ宋ス。上皮 $(\mathrm{EP})$ ノ粗荧二八强度ノ細胞浸潤並二 充血 $\ni$ 見儿。 


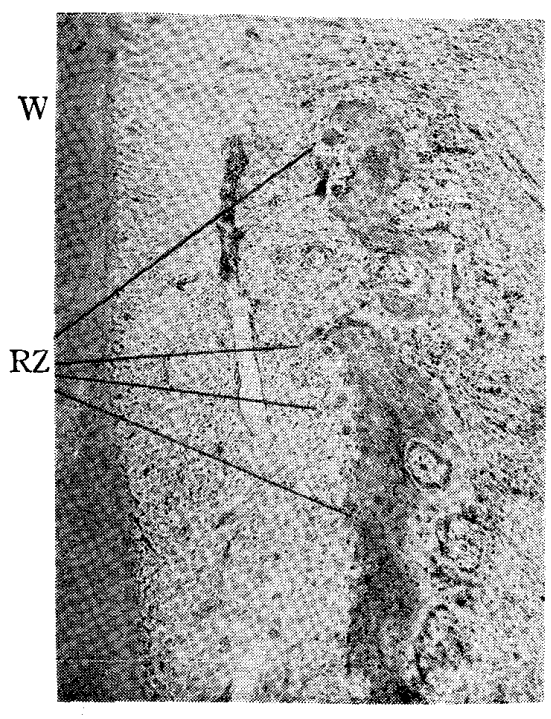

第三士五圖

第三三圖 $\mathrm{Y}$ 部, 援大

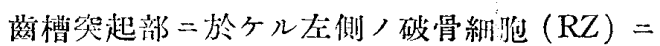
依儿筒狀吸收 7 㲔メラル、右方八生理约骨新 生ノ像アリ。

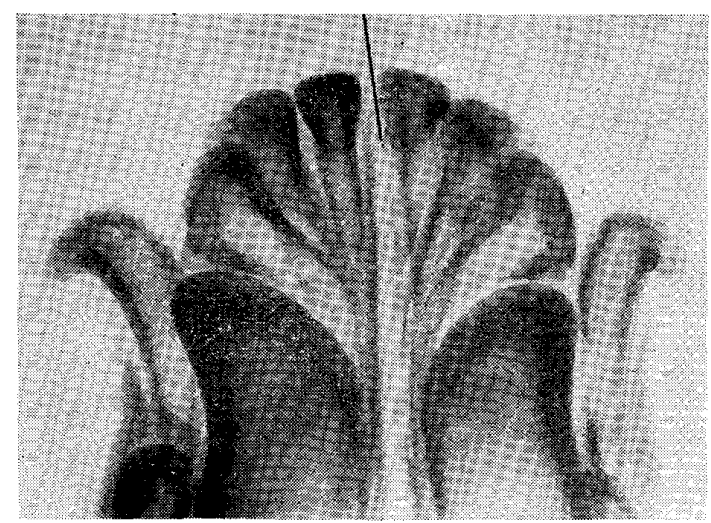

第三十六圖

第正群 $\lceil\mathrm{O}+Z$ 添加群

No.47 合 78月死

下顎前茼部ノ $\mathrm{X}$ 光線像ニシテ、正中線矢印部 $=$ 於テ明ラカ二骨費ノ消失 7 認メラル。

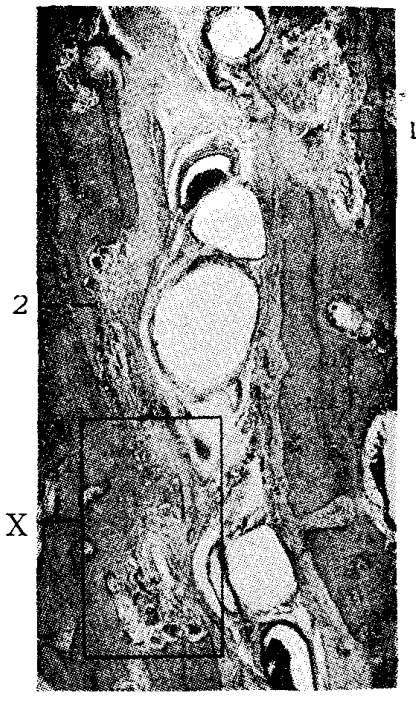

第三十七圖

前圖矢印部ノ組織慗本ニシテ、1、2 及ビ $\mathrm{X}$ 部= 於テフ明ラカ二多数，破骨細胞，出現二依りテ 等質ノ吸收セラレッ、アルラ認メ得。

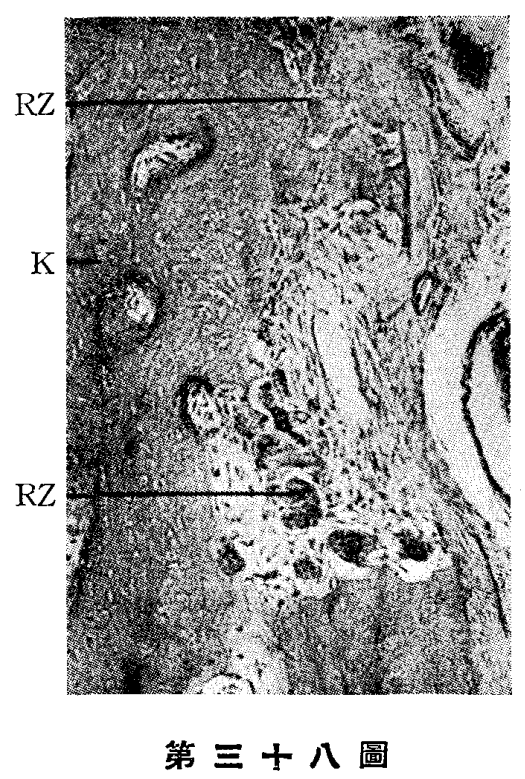

前圖 $\mathrm{X}$ 部ノ强搟大

破骨細胞 $(\mathrm{RZ})$ ）出現二依リテ蹇狀二吸收七 ラレッ、アルラ認メラル。 


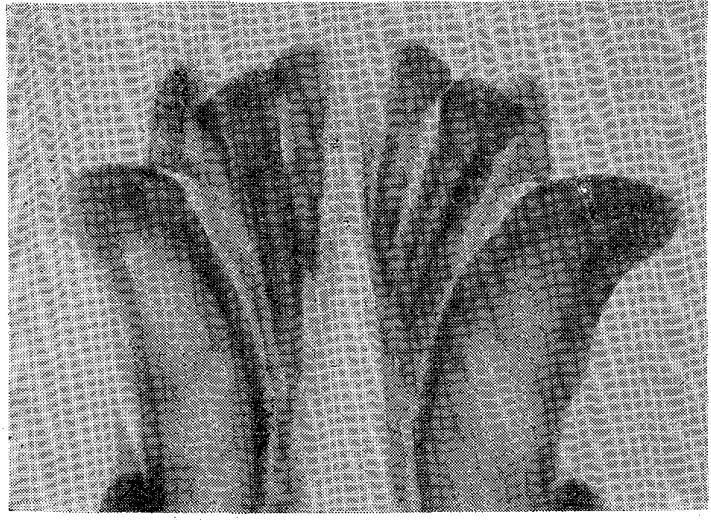

\section{第三十九圖}

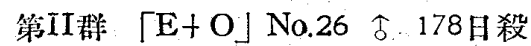

下颚前蓄部ノ「レ」線像圖、一般二骨海綿質八烦

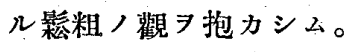

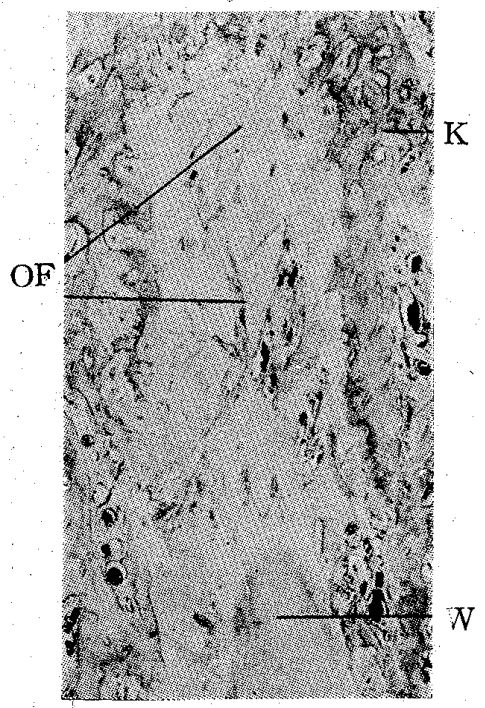

第四十圖

前圖, 切州標本

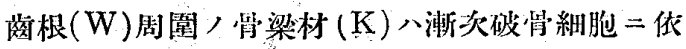
リテ吸收セラレ、結締組織二侬り㯰換セラレ先 二纎維性筲策養障害 (Osteodystophiafibrosa $O$ F) 二移行セリ。

此ノ如ク堅固ナルベキ骨梁が結締織二依リテ

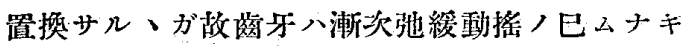
ニ至ルベシ。

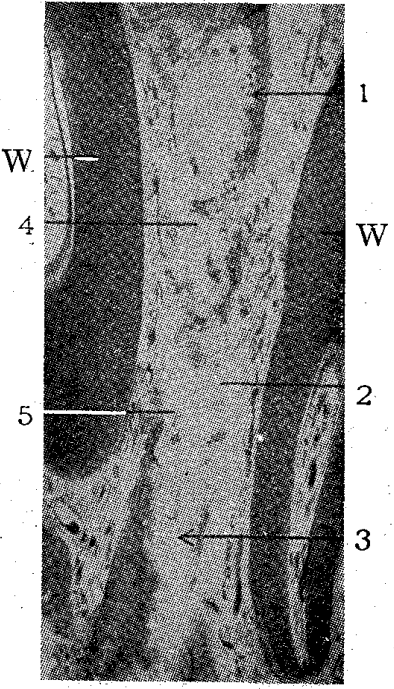

第四十一圖

第井九圖ノ切片

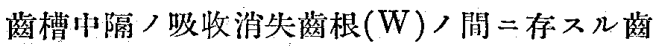
槽灲隔ハ1.2.3.4.5. 广部分二於テ殆ンド吸收消 失シ、骨ノ繊維化 7 來セリ。

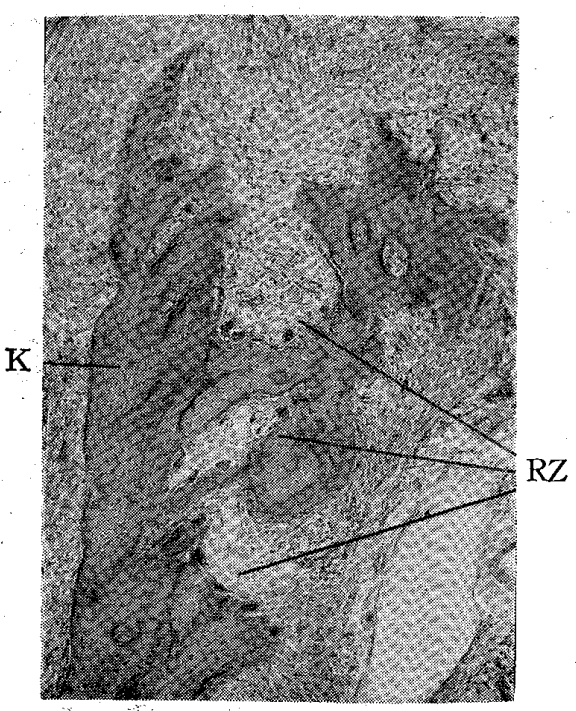

第四十二圖

第IV群 $\Gamma Z+\mathrm{E}+\mathrm{O}$ 」添加群 $\mathrm{No.62}$ 우 $395 \mathrm{H}$ 殺 齿槽突起二於ヶル吸收現象。隨所二破骨細胞 $(\mathrm{RZ})$ ノ出現ラ認メラル。 


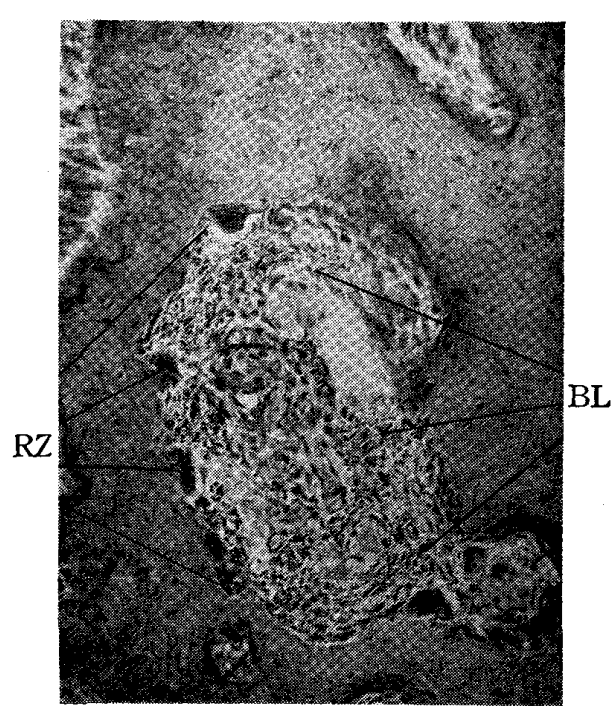

茅四十三圖

第山群「E+O添加群 No.31 우115日殺 ヘーヴメルス氏骨ノ擴大ヨ示ス。

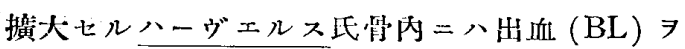
認メラル。

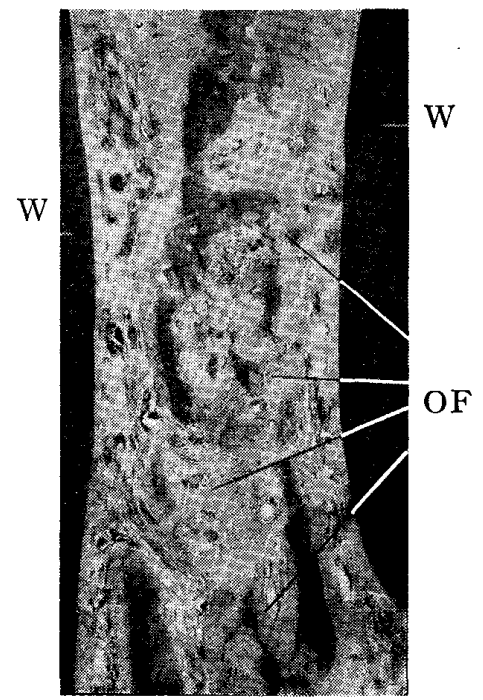

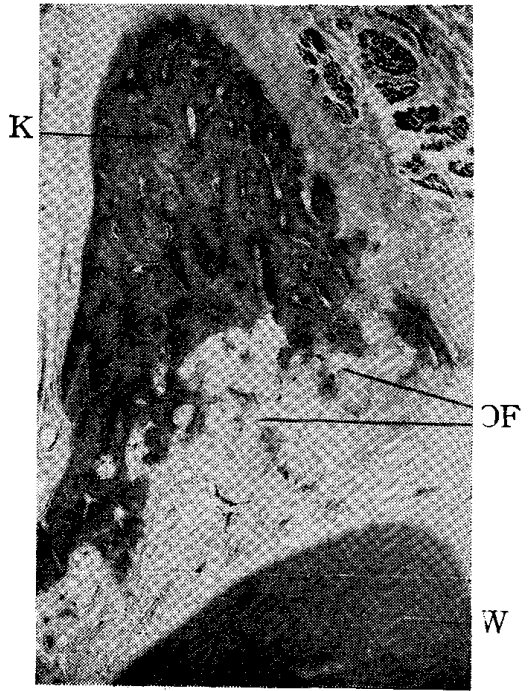

第四十四圖

第I群 $\lceil Z+E$ 添加群 No.8 우 151 日殺

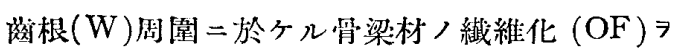
示ス。

\section{第四十五圖}

第II澼 「E+O」添加群

No.26 字 178 日殺 苳槽小隔ノ緎維化 $(\mathrm{OF}) \Rightarrow$

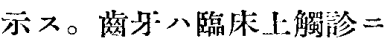
際シ塹度ノ弛緩動搂ヨ示シ 估レリ。

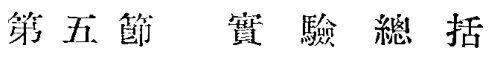

幼犬フ为ヒテ含水炭素(䈳糖)、蛋白質(牛蛋白)、脂肪物質(オレフ油)ノ三者ヨ互二配合シテ 常食二添师シ以テ主養素) 偏食實驗 フ行フトキハ實驗動物ハ概シテ全身)發育障害シ招來スル

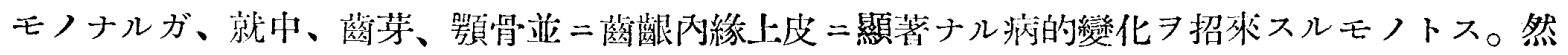
レドモ幽ニ八䔄硬縕織ノ變化ヨ除外シテ記載セントス。

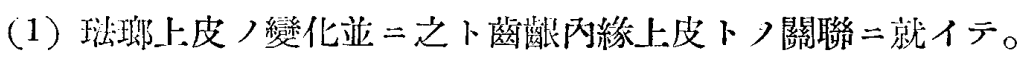




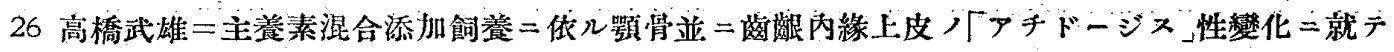

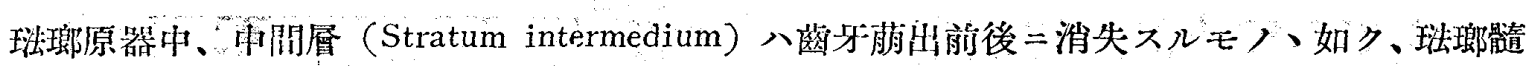

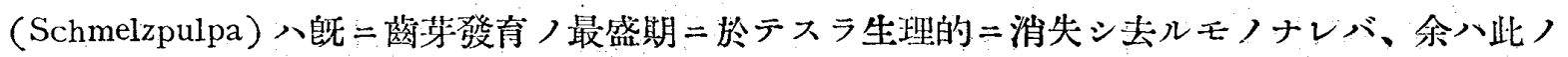

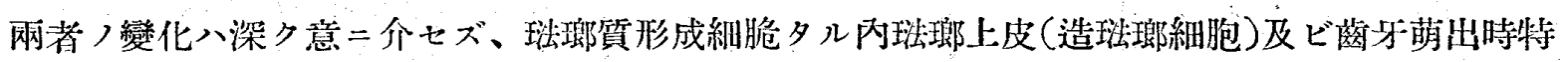

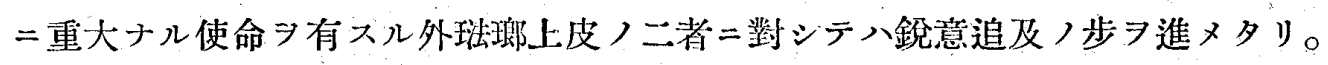

先ヅ內外理瑯上度ノ變化一括スレバ次ノ如シ。

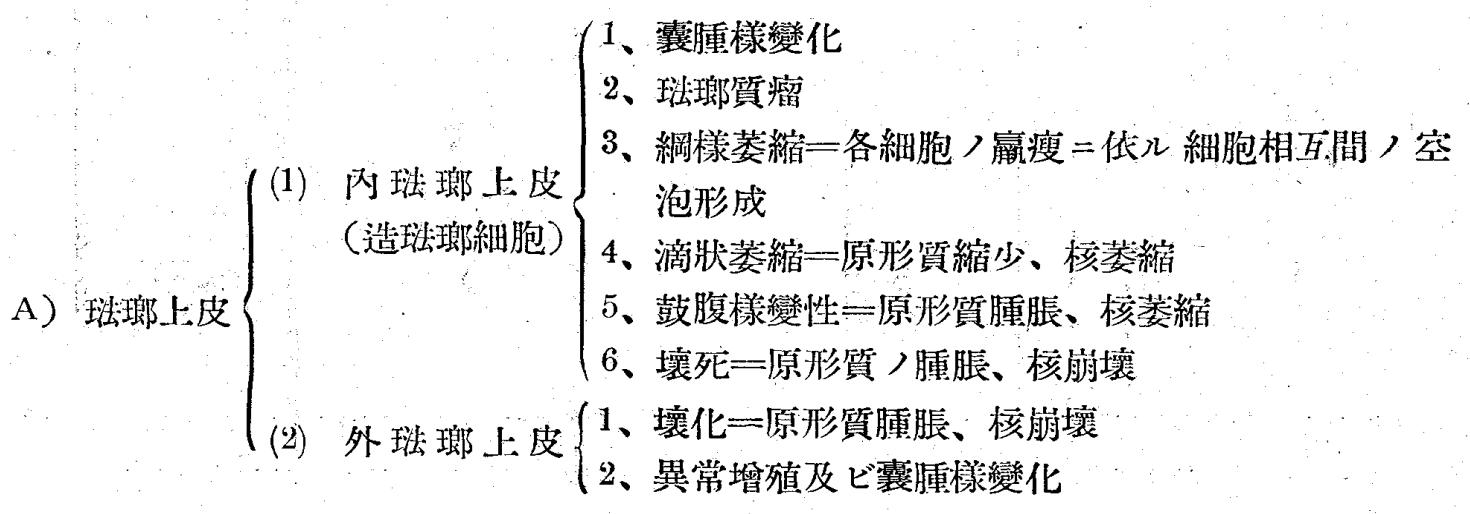

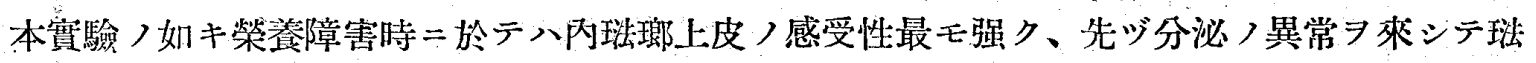

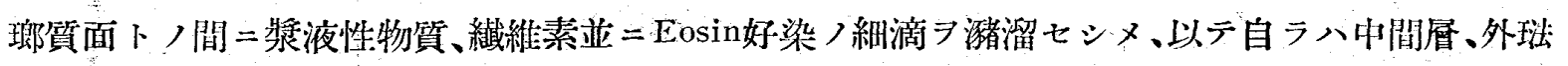

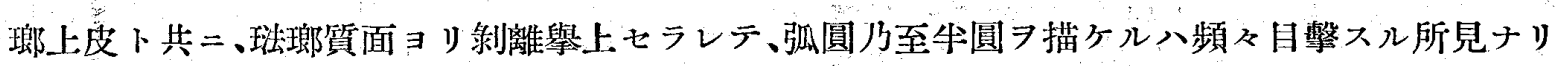

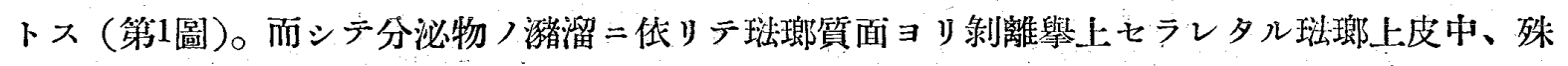
二內脏瑯上皮八二次的二退行萎縮シ、空隙中一脫落シ（第 2 二圖）、次イデ八圓形ノ球滴トナリ

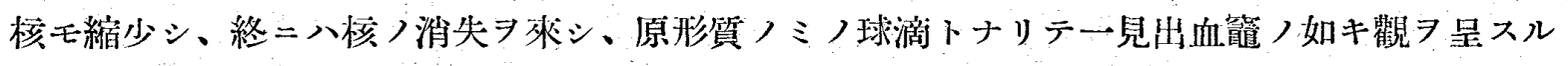
コト稀レナラズ（第6、第 7 圖つ滴狀萎縮）。他方二於テ利離舉上セラレタル內理瑯上皮卜踓壬

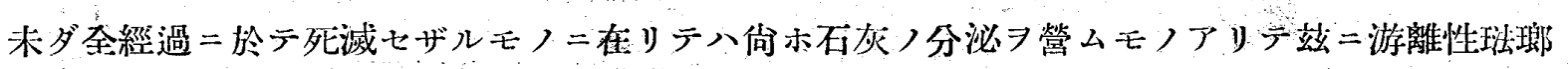
質瘤 (freies Adamantikel)，H現フ認么ルコトアリ。

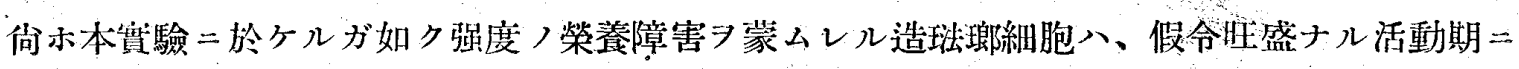
際會スルモつ二在リテスラ著シク退行變性ニ陷リ其ノ高經 フ減ジ或入矩形トナリ核モ濃縮シ、

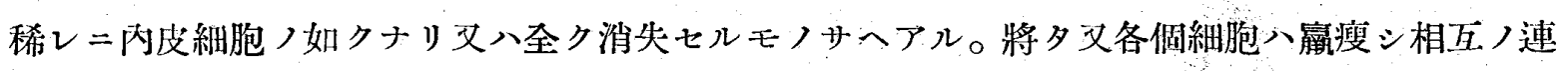

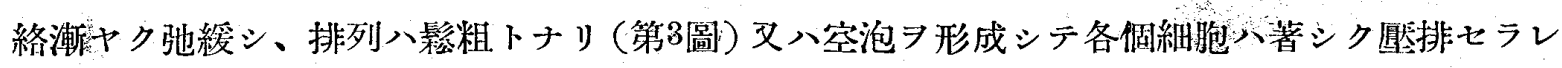

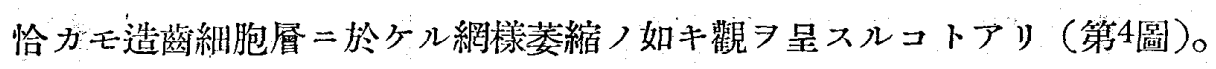

以上ノ如キ退行萎縮ニ止マラズ造㻦瑯紐胞つ變性つ一型トシテ原形質腫脤ジ鼓腹つ如クナリ 核八寧口濃䋨シテれ央二占在シ鼓腹樣變性 (ballonierende Degeneration) =陷》、終二八核 消失ヨ來シ原形質ノ融解ヨ゙來スコトア゙リ。

又强度，榮食障害二陷レル場合八原形質八著明ナル腫脹ヨ示シ (Protoplasmaaufquellung) 漸次核ノ崩壞 (Karyorhexis) ヨ招來シ、壞死ニ陷ルモノンシテ、此ノ如平所見ハ未ダ文献二記 
载ナク一見巨大細胞ノ如手觀アレドモ、核ノ不正形分裂ニ低リテ鑑別シ得ルモノニシテ細胞變

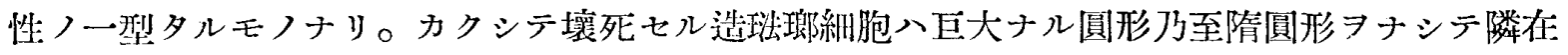

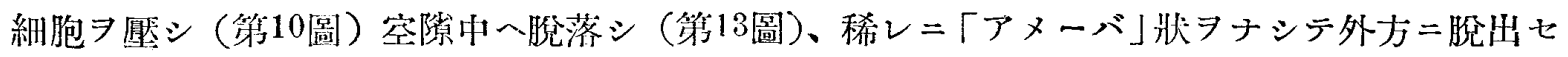
ントスルモノアルテ (第16圖) 其ノ所在八必ズシモ一㥞ナラズ。而シテ壇死セル細胞八終ニ八 原形質)融解习來スル至ル（第11圖、第13圖 $\mathrm{NZ}_{2}$ )

他方二於テ榮養障害時二於テ外㻕瑯_上皮（äutzeres Schmelzepithel）壬亦原形質腄脹シ、核崩

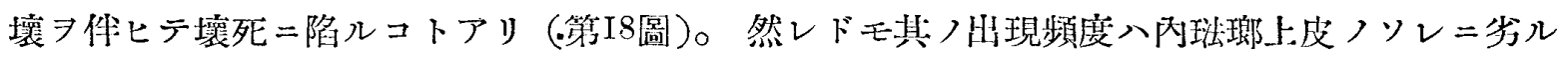

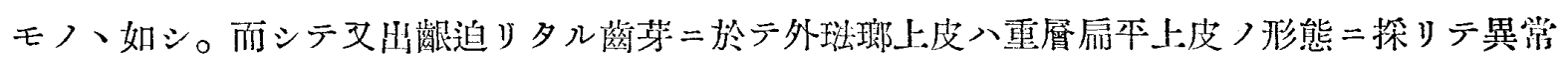

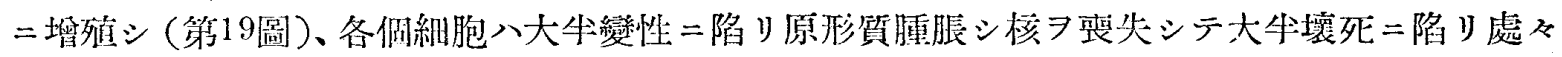
二囊腫鉒變化

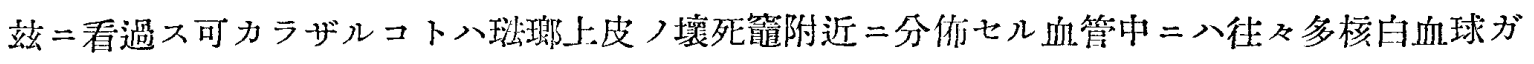

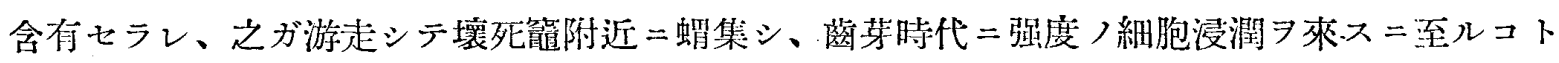
アリ（第28圖）。

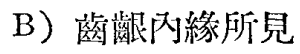

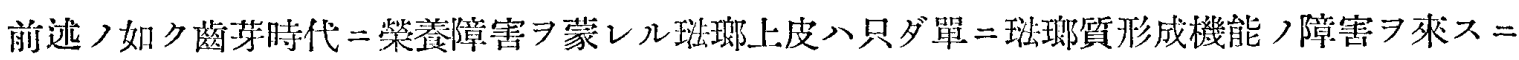

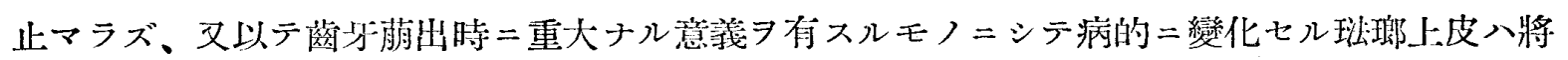

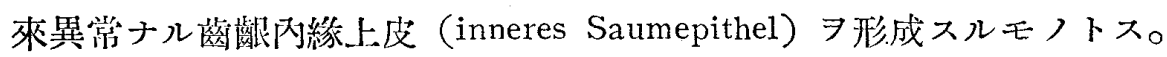

其ノ變化ヨー・括スレバ次ノ如シ。

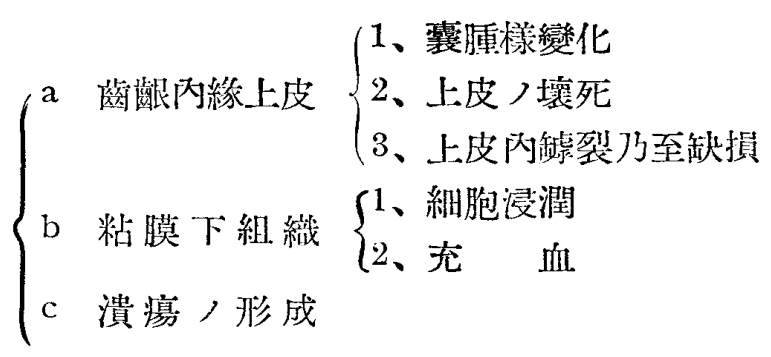

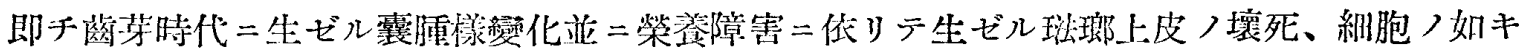

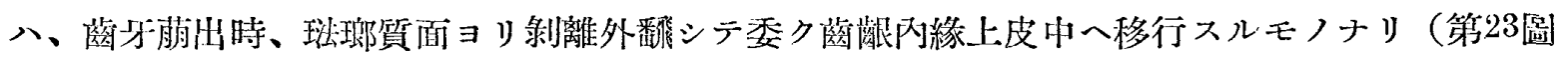
第24圖、第26圖、第32圆)。

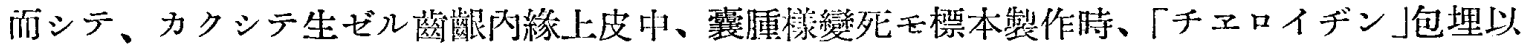

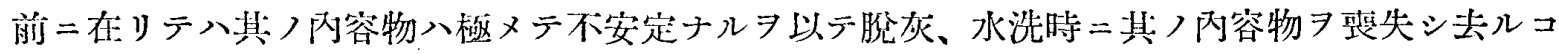
トアリテ茲二器械的產物二屬セザル上皮冈鐻裂 (interepithelialer Riss) ヨ撥現セシムルコトア リ（第23圖ER）。

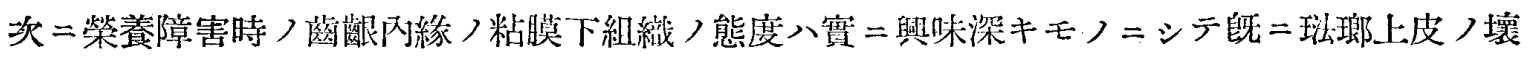




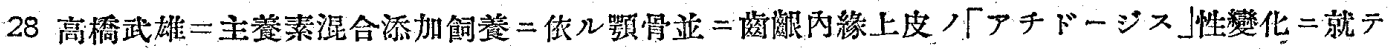

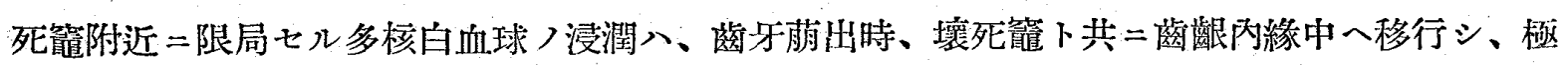

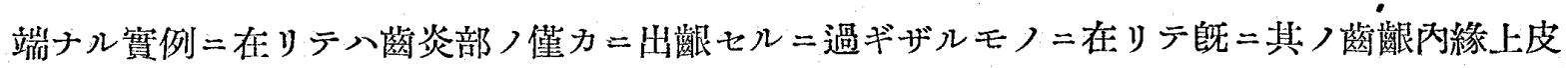
つ粘膜下 $=$ 於テ多数 つ多核白血球 浸潤 7 確認スル

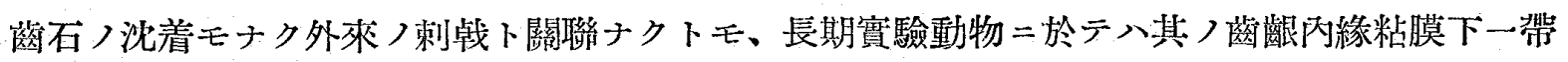
二强度ノ細胞浸潤习認メラレ、且ツメ毛細血管ノ充血怒張アリテ、美麗ナル像フ結ブモノ多ク

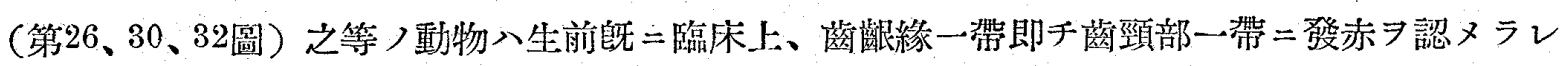

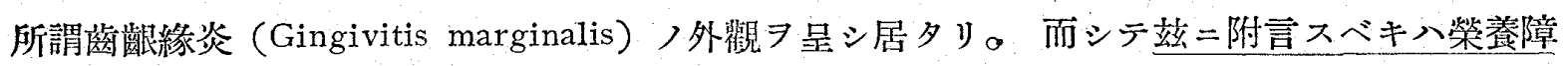

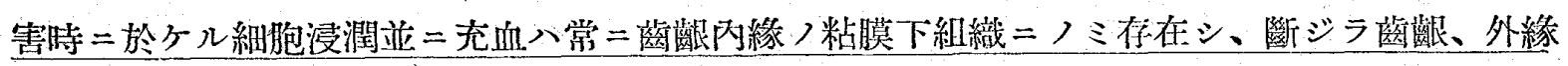
即チ口腔粘膜下二之ヨ認メ得ザリシコトナリ。

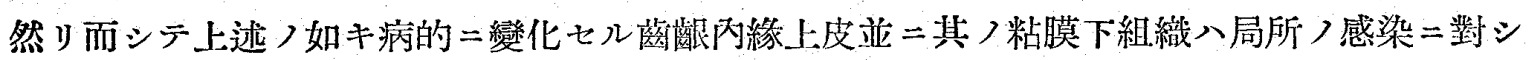
デ抵抗弱クシテ、犬ノ口腔常仿菌ノ自然的感染

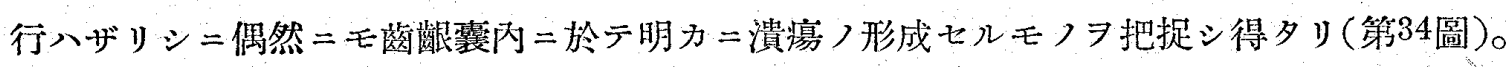

II) 顎 骨 變 化

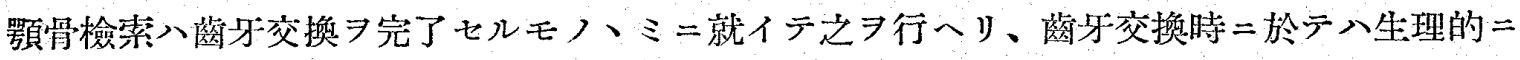
吸收新生入再機轉ガ最モ旺盛ニ營マレツ、アルラ以テ特ニ此つ期フ避アタリ。

各群

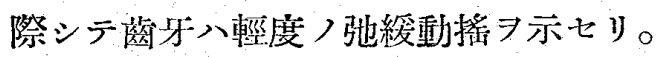

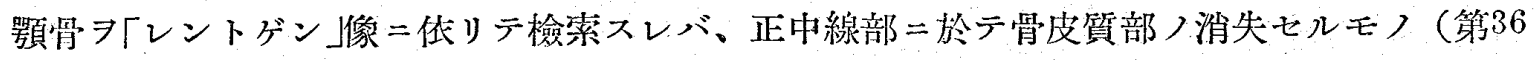
圖）或八骨·海綿質八極メテ鬆粗）觀 シ抱カシムルモノアリ(第39圖)。

組織學的檢索二低レバ、正中總部ノ骨皮質部或八缹槽中隔骨梁二八多數ノ破骨細胞ノ吸着 觀ル。吸着セル細胞八極メテ巨大、核モ亦梄メテ鮮明ニシテ最モ旺盛ナル活動期二際會セルモ ノ(第38圖) 或八胞體小ニシテ核モ鮮明フ缺ギ既二沫動期フ經過七ルガ如キモノモアリ。炏イ

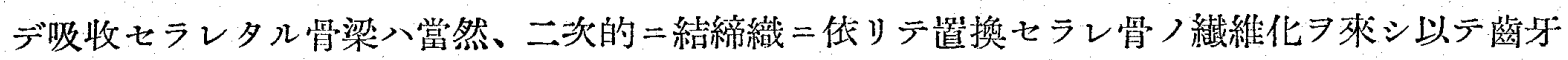

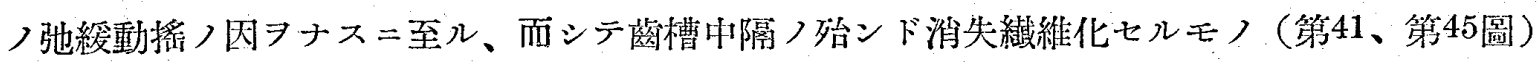
缹根雕園二之ヨ有スルモ（第40、第44溘）アリ。

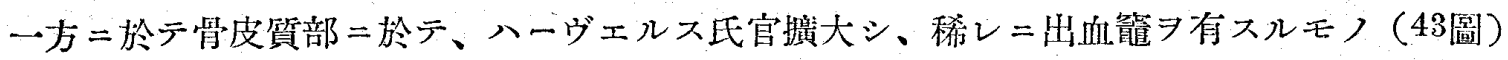

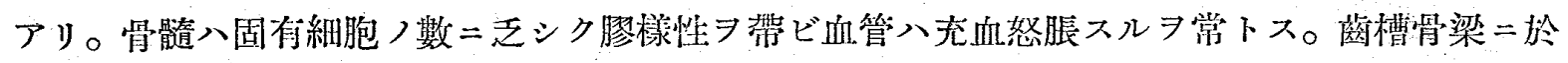

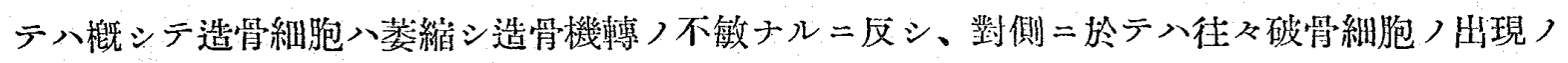
增加ヨ認メラル。

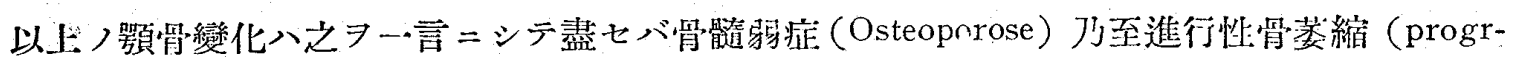

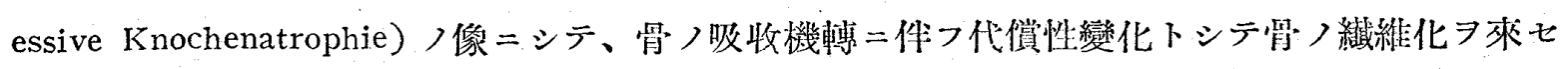

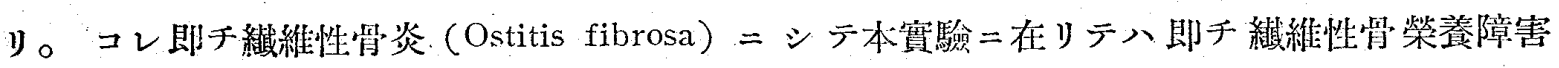


(Osteodystrophia fibrosa) ナリ。然限局性ノモノニ非ズシテ霉漫性葁縮（diff use Atrophie） ニシテ Osteodystrophia fibrosa generalisata ニ屬スベキモノトス。

\section{第三章考按}

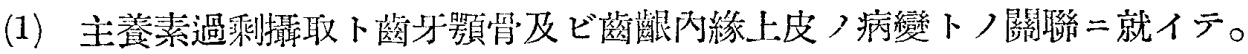

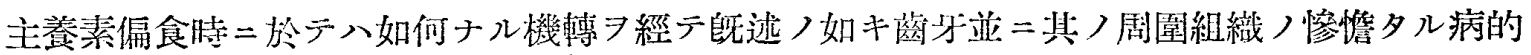
變化シ招來スルモノナリヤ。其入因ハ之ア有機養素過剩攝取時＝發見スル血液「アチドージス」 ニ蹼セシム 7 得ベシ。（壟、主養素過剩攝取時ノ血液內炭酸瓦斯含有量ノ消長ノ襝索並二成績 八口腔病學會第8卷第3號

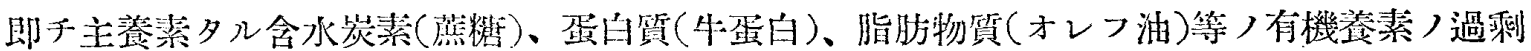

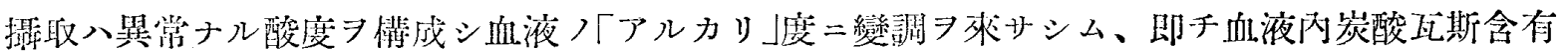

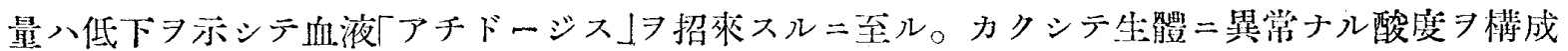
シ之ガ住續スル限リ八其入代償機德トシテ「アムモニア」ノ轉向等二破綻ヨ來ス八明カナレドモ

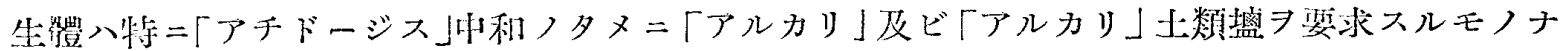

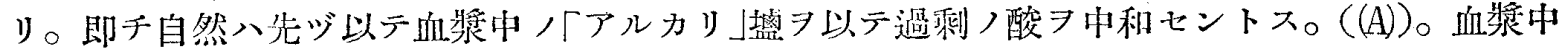

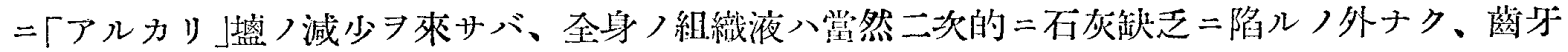
顎霄ノ細胞入特二菇大ナル影響シ蒙ムルモノトス。

主洷㨞佰食

血液アチドージス

排 泄)

Is 利

稳成骨

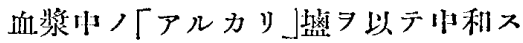

シ小和 ス

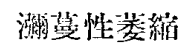

石灰缺乏

濔营性㵶維性 骨榮春障害

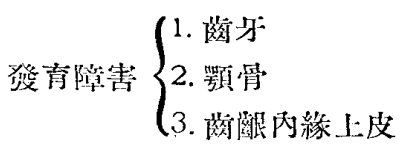

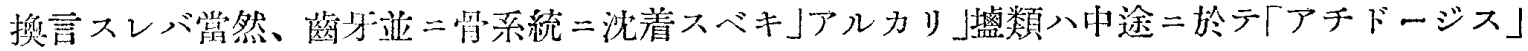

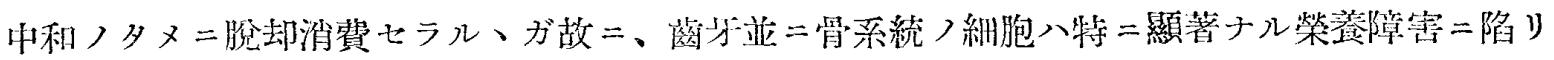

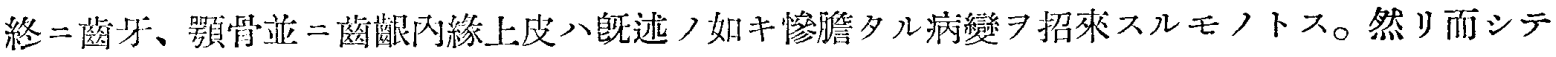
血漿中ノ過剩ノ酸

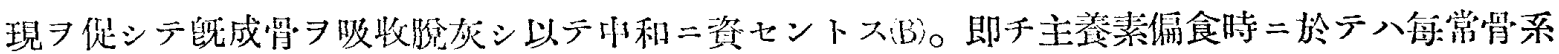




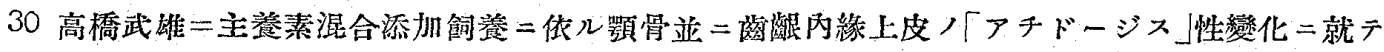

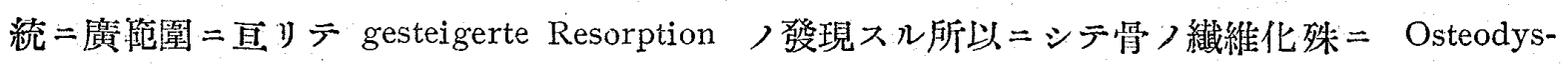
trophia fibrosa generalisata ノ發生八唯ダ其入代償性變化二過ギザルモノトス。

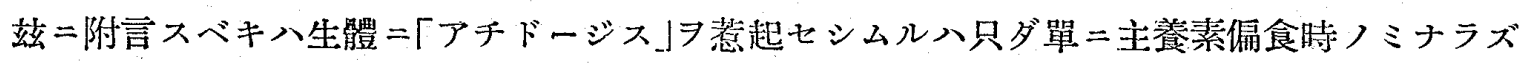

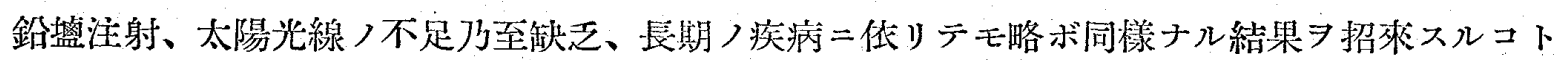

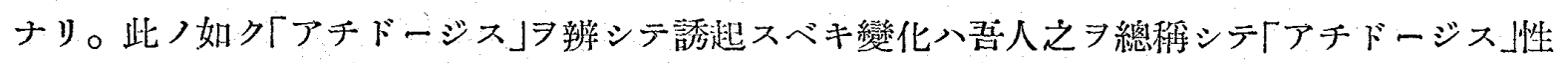
變化卜命名シ居レリ。

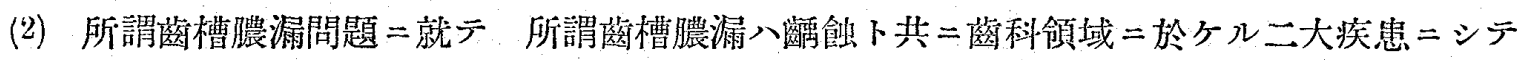
其ノ重要性ニ於テハ寧口後者ヨ凌グ觀アリ。本症二類スルモ，記載ハ、既二西曆紀元前ヨリ 之ヨ認メラル、モ、齒槽膿漏ナル名揫八1846年伊太利人トライラック・デジラボド氏ノ命名二其

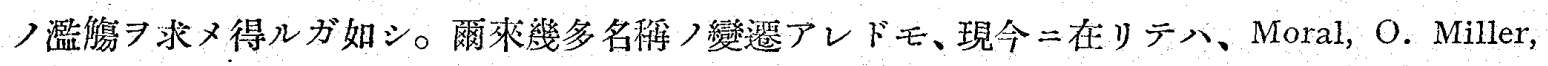
Cohen 八依然トシテ Alveolarpyorrhöe ナル名稱ヨ用市ルニ對シ、Weski ハ Paradentose 族

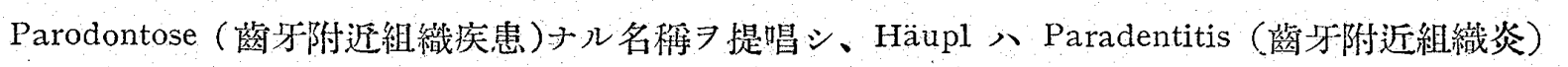

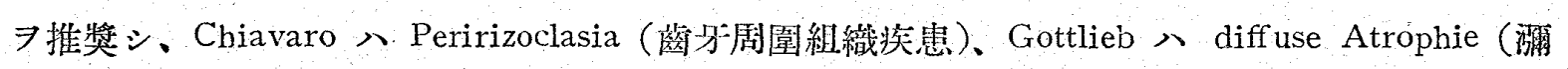
夢性萎縮)及ビ Paradentalpyorrhöe (遥牙附近組織膿漏)、W. Meyer > Periodontitis marginalis

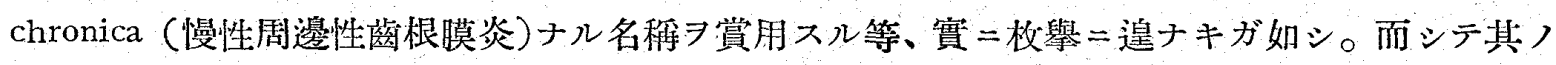
原因二至リテ八或八局所說、叉八全身說り至八混合說アリテ未ダ閭・スル所ナク全ク五里霧中 ヨ彷得スルノ觀〉リ。

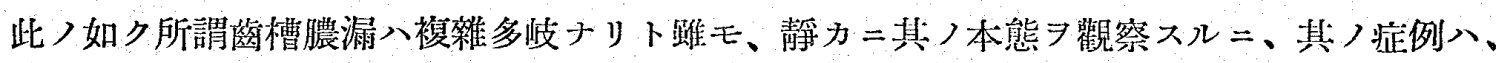

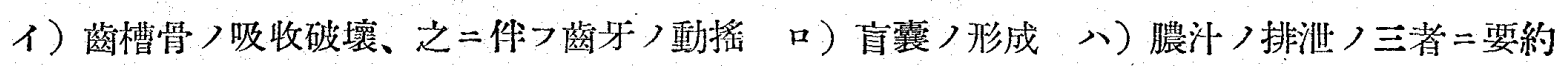

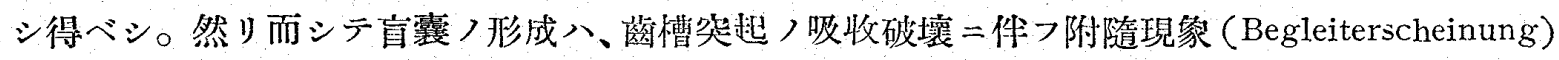

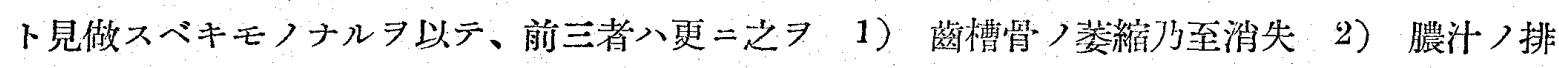
泄即チ潰湯形成ノ二者二歸セシム 7 得ベシ。然リ而シテ此ノ二大現像八本症ノ初期型態ニ在リ テハ必ズシモ兩立シ得ザルモノナリト踓モ其ノ晩期成熟型ニ在リテハ不可缺ノ篮例ナリトス。

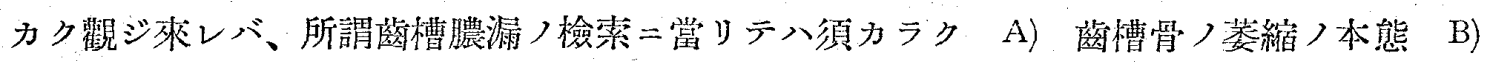

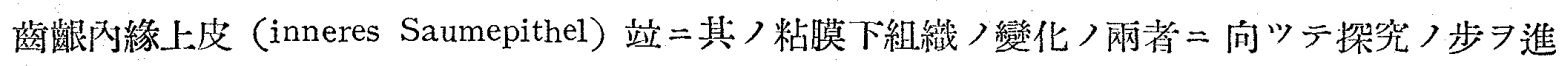
メザル可ラズ。余八此ノ如キ根本方針ヨ樹立シ、以テ本實驗二著手セシモノナリ。

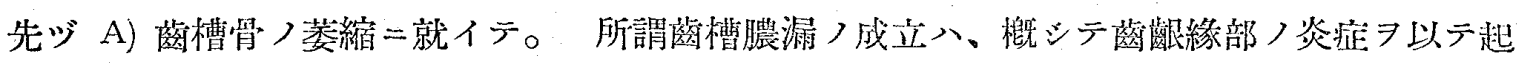

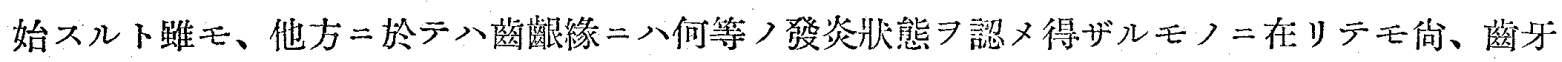

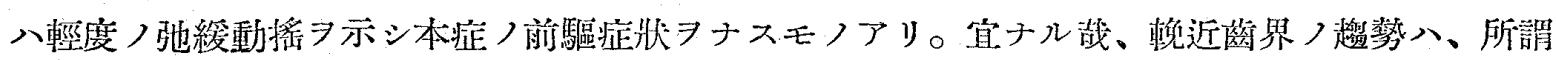

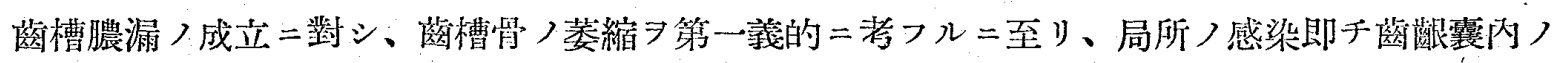

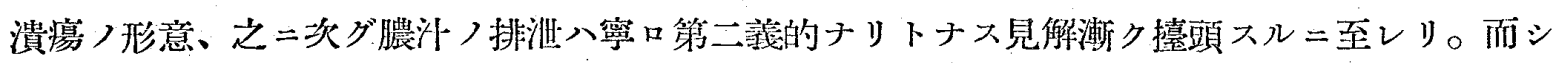

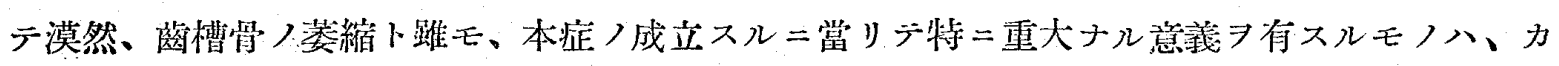




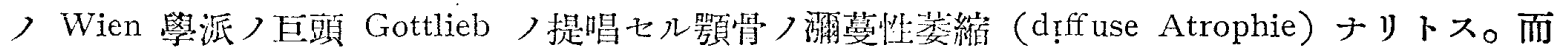

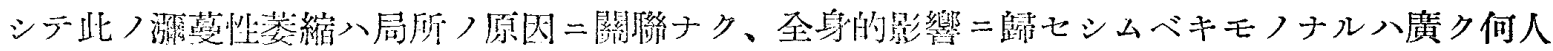

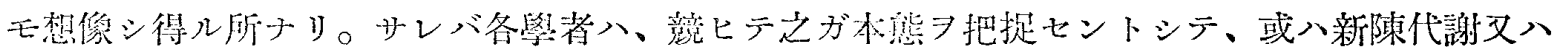

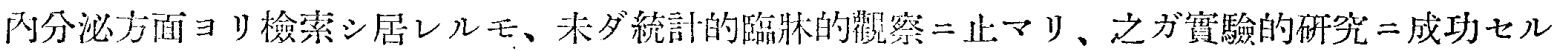
者無カリキ。

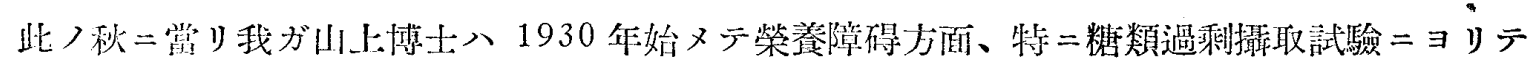

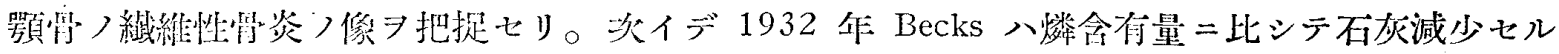

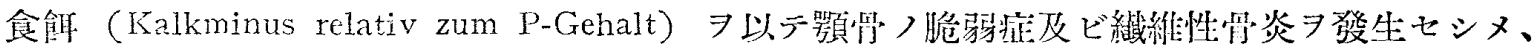

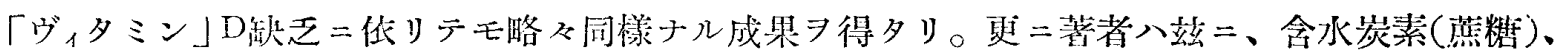

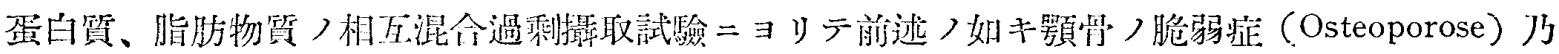

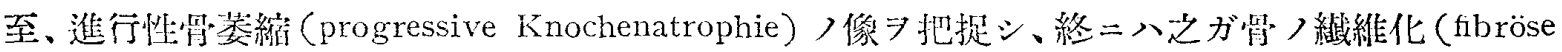
Uंmwandlung) =移行スルモノナルフ碓認シタリ。

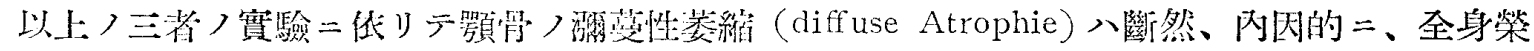
餋障碍ノ一部現像（Teilerscheinung）トシテ發現シ得ル亡ノナルラ立證シ得タリ。而シテ是等

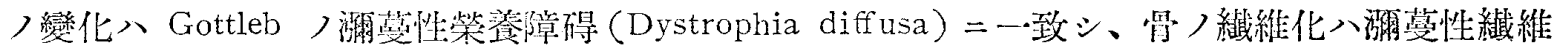

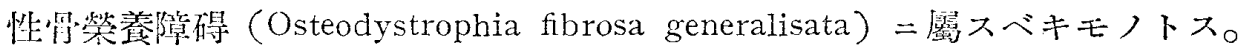

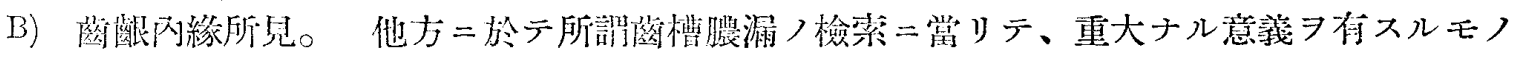

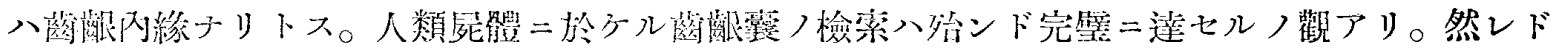

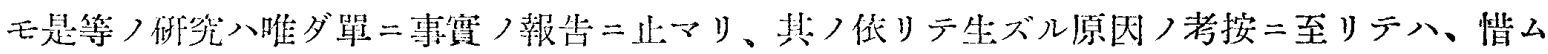

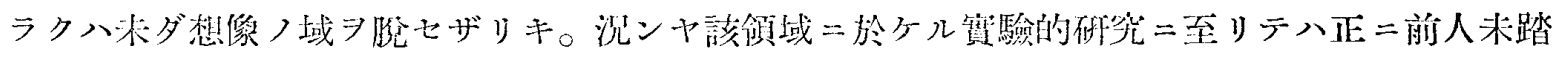

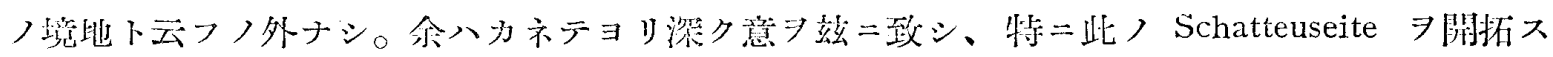
ルラ以テ本諭文ノ大生ノ使命トナ七シモノナリ。

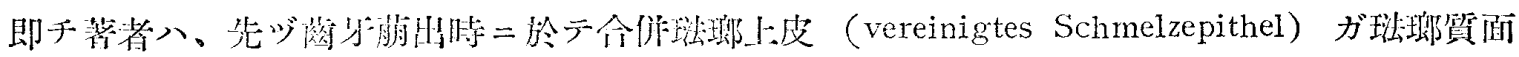

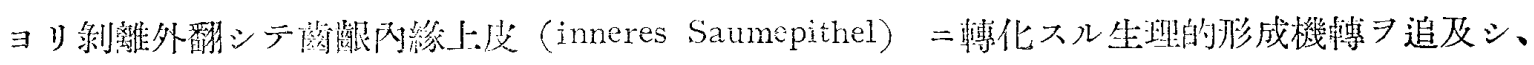

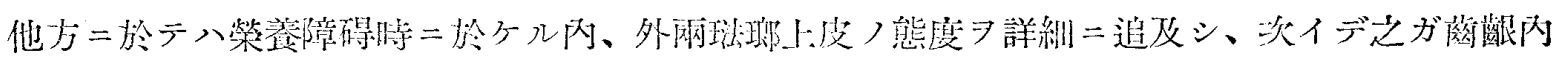

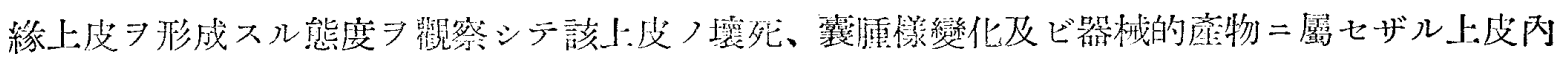

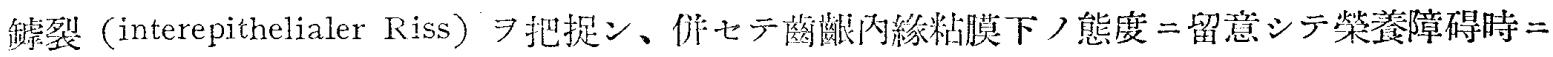

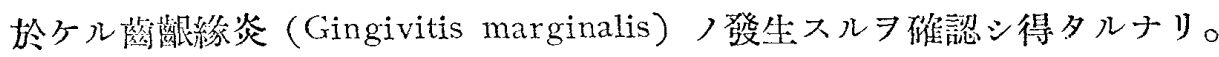

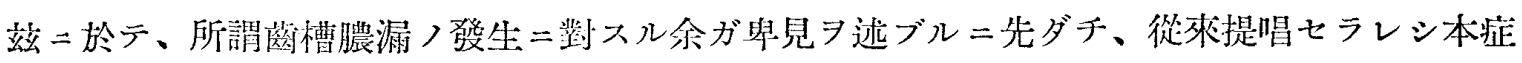

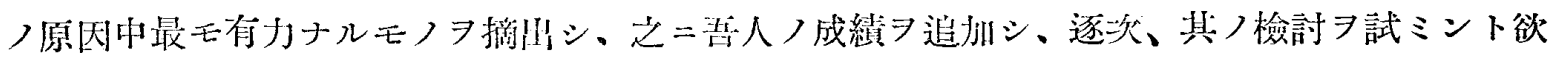
ス。先ヅ是等フ裴示スレバ炏ノ如シ。

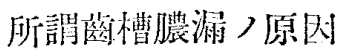




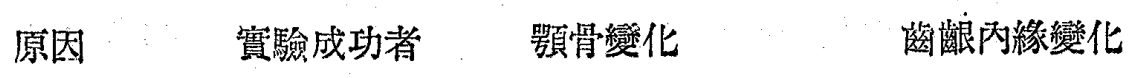

\section{I) 外因}

\section{1、蓖石}

2、感染

潰燱形成

3、負擔過重

Gottlieb

限局性骨變化·

Orban 1931 年

4、䛯用 ·限局性骨變化·・”。

.. $\times$

II) 內因

1、新陳代謝 $X$

2、荖人性變化 $x$

3、內分泌(上皮小骾機能元進)

4、榮養障碍
A) 缺乏試驗

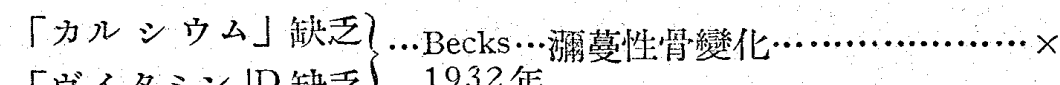 「ヴイタミン」D缺乏 1932年
B) 過剩攝取試驗

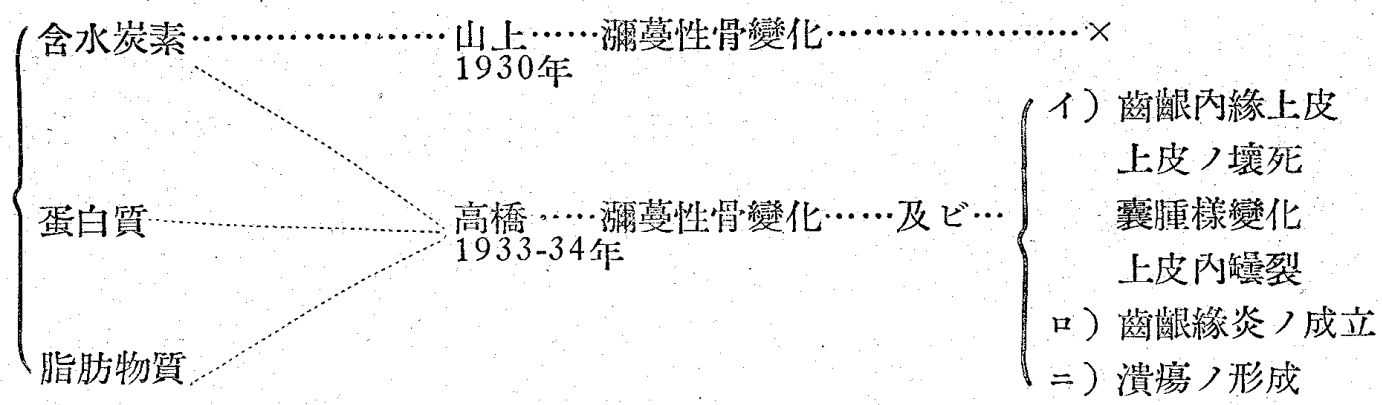

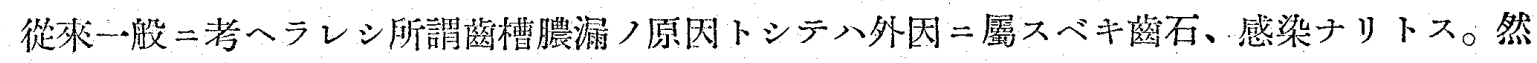

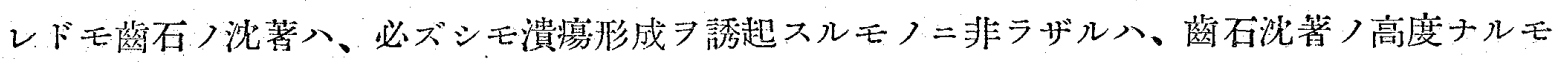

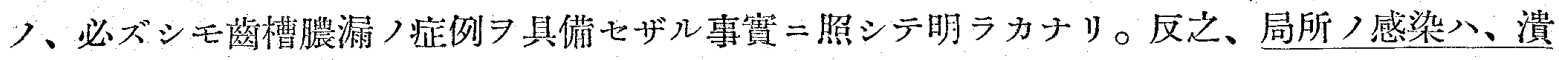
瘍ノ形成＝龊シテ、必須ノ先驅條件タルハ吾人ノ等シク認ムル所ナリ。之フ至言ナリトスレバ

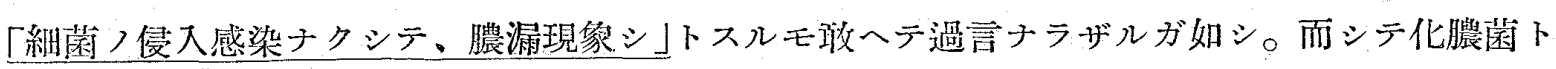

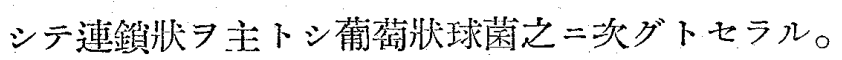

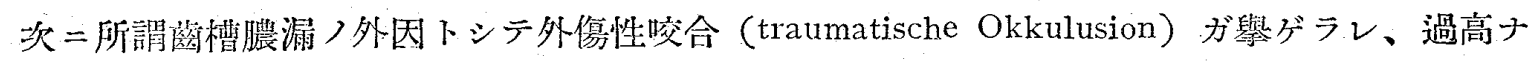

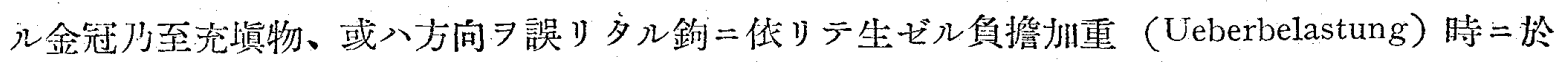

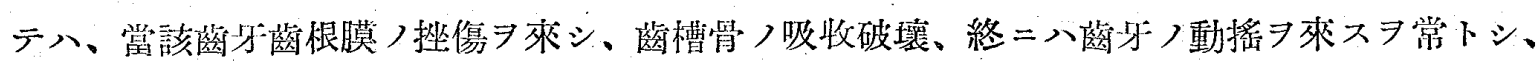

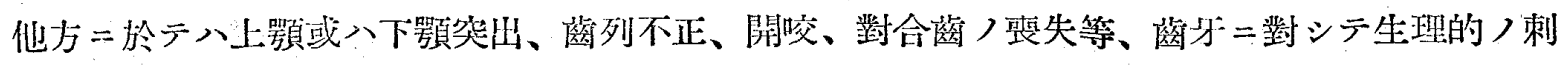




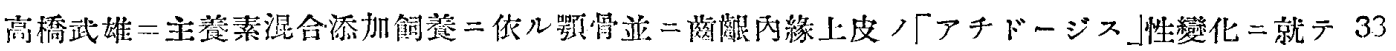

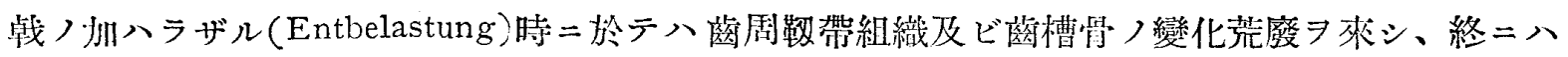
該組織ノ廢用性菱縮ニ到達スルモノトス。而シテ前者二向ツテハGottlieb 及ビ Orban 八精密

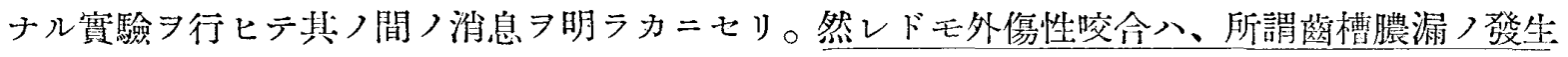

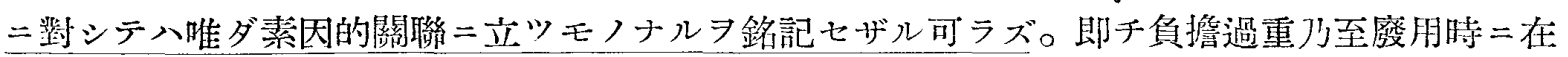

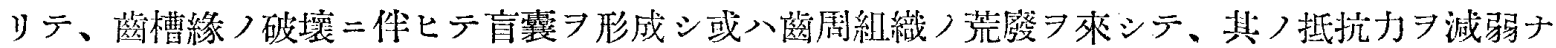
ラシムルガ故二、局所ノ感染二對シテ感受シ易ク終ニ八膿漏現象＝到澾スルモノトス。約言ス レバ脤汁ノ排泄入、外傷性咬合ノ二次的現象ニ外ナラズ。而シテ更二弦二注目スベキハ外傷性

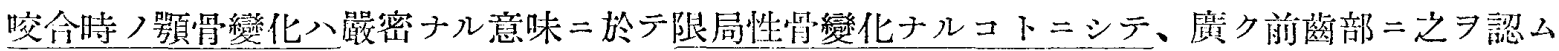

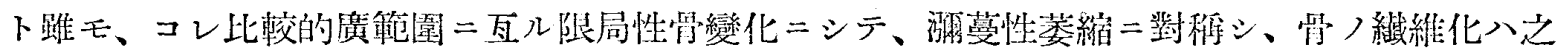
＼cjkstart煺局性纎維性骨炎（Ostitis fibrosa localisata）二屬セシムベキモノトス。

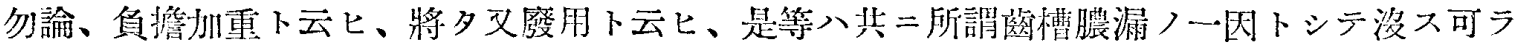

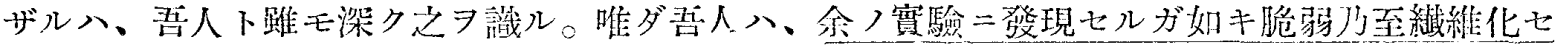

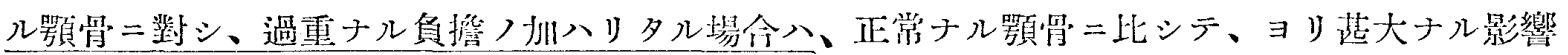

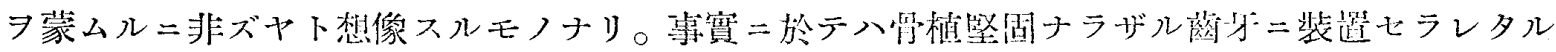

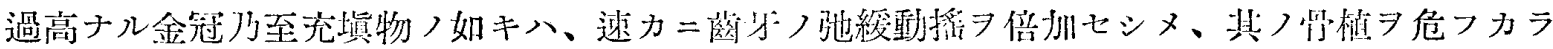
シムルニ至ルラ管トス。

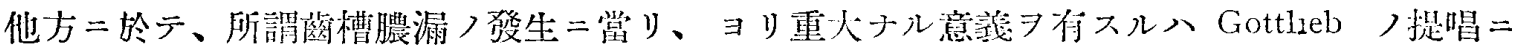

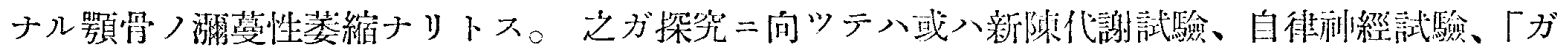

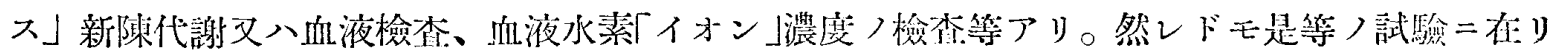
テハ未ダ確固不找ノ結論二到達セザルガ如シ。

例之、Citron, Cohen 等ノ行へル血液化學的定量分析=伶ケルガ如ク、diffuse Atrophie 下血

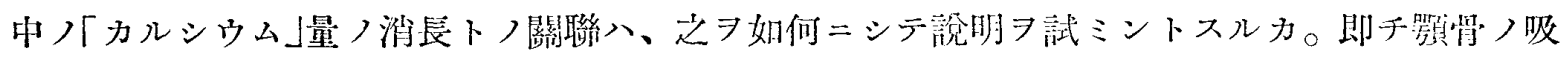

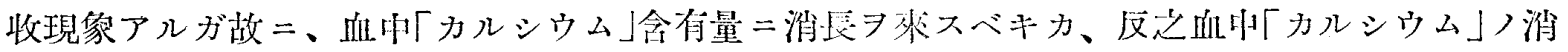

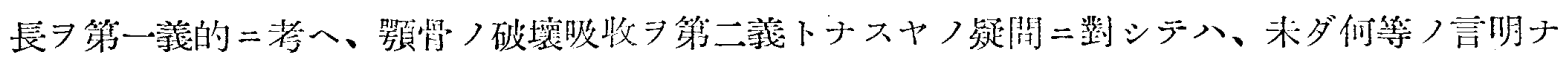

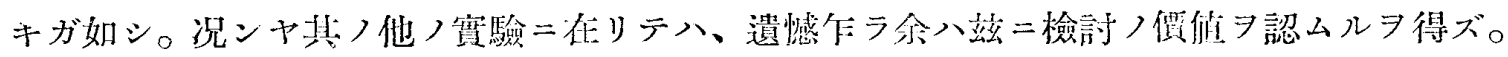

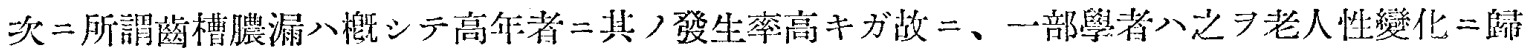

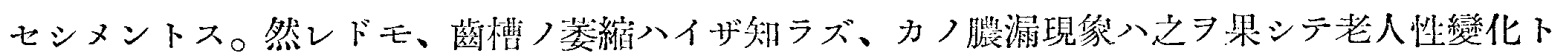
見做シ得ルヤ否ヤ、更二再考つ狳地アルモノトス。何ントナレバ、膿汒ノ排泄八即チ局所ノ感

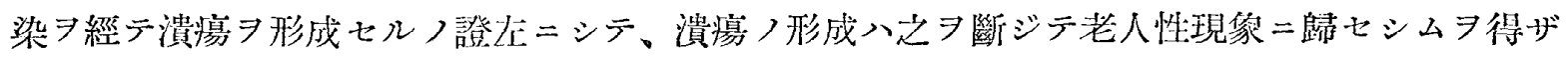
ルガ故ナリ。

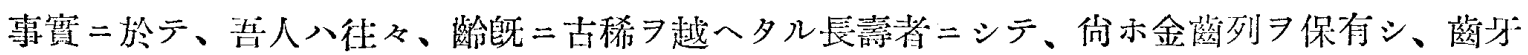

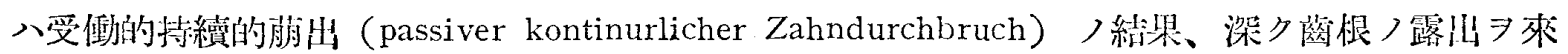




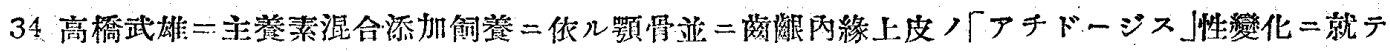

セルニ拘ラズ、骨植低然トシテ堅固ニシテ、膿汁ノ排淮入之ヨ認メ得ザルモノアル二遭遇ス。 余タシテ忌临ナク言ハシムレバ、此)如キ茼糟骨) 退縮コソ明ラカニ老人性萎縮 (Atrophia

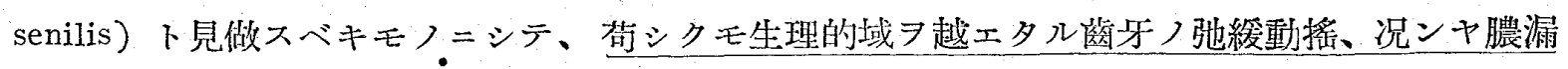
現象ノ發現スルニ於テハ、最早之フ老人性變化二歸セシム可ラザルモノナリト確信ス。

次二吾人ガ深丰興味ヨ感ズルモノ八內分泌、殊二上皮小體（Epithelkörperchen）問題ナリト

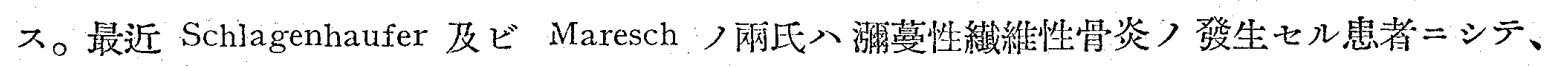

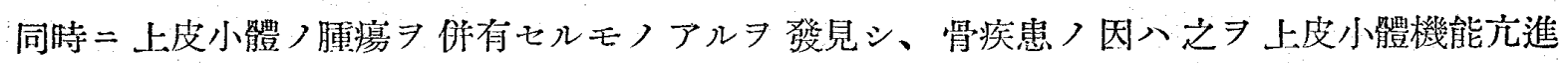
(Hyperparathyreoidismus) =歸スベキニ非ズヤトセリ。次イデ Mandl（1925年）八骨疾患

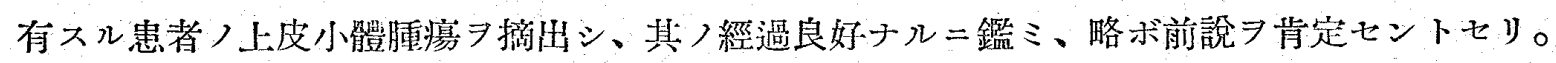
更二最近ニ至リテJaffee 及ビ Bodansky ハ其ノ間ノ消息シ闆明ナラシメントシテ、之ガ實驗

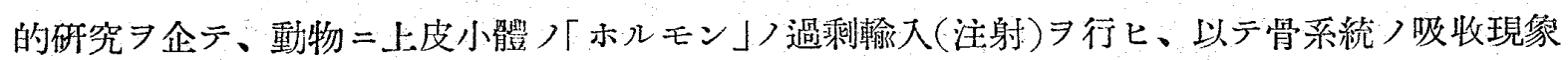
ヨ把捉シ得タリト報告セルモ、未ダ的碓ナル成續二到避セザルガ如シ。茲二於テ吟味スベキハ

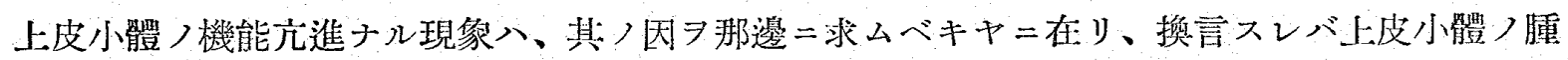
瘍入如キハ之ヨ原發性疾患卜見做スベキヤ否ヤ。玄二於テ想起セザル可ラザルハ、往年、片瀨

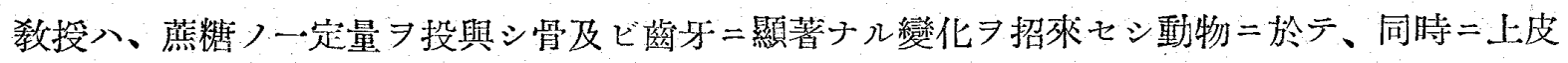

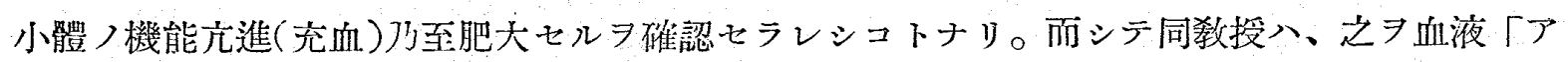
チドージス」時ノ石灰新陳代謝異常二因スル續發性現策ナラント考按セラレタリ。惟フ二血液 「アチドージス」時二於テハ、既述つ如ク石灰新䏂代謝つ異常ヨ誘起スルモノニシテ、タメ二血

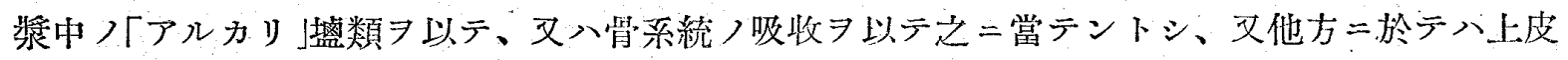

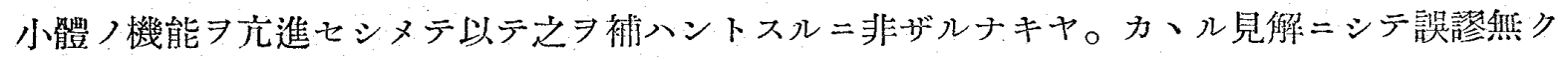

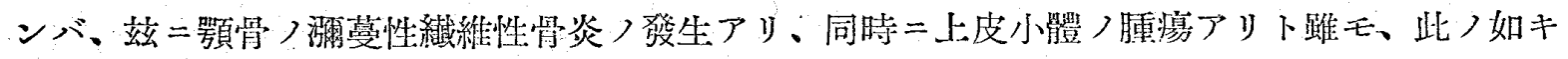

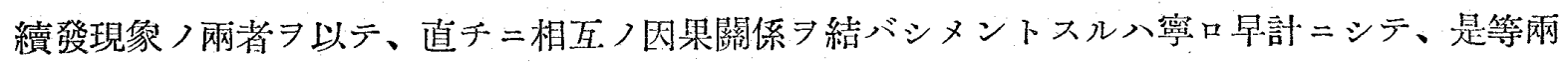
症例 因八宜シク根源二遡リテ、石灰新陳代謝異掌习惹起スベキ條件、例之、血液「アチドー

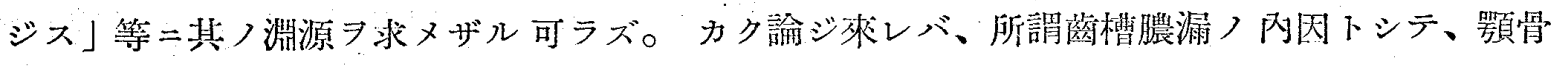

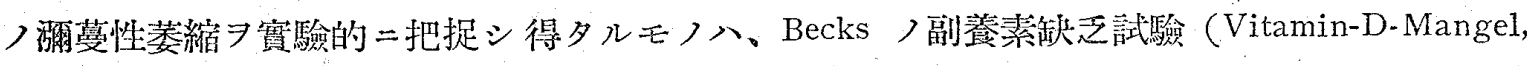
Kalkarmut）、、吾人ガ行へル主食素つ過剩攝取試驗シ算スルニ過ギザルノミ。

全テ發育中ノ動物、乳兒、小兒八、成熟セルモノニ比シテ、相龂的二多量ノ「アルカリ」及ビ

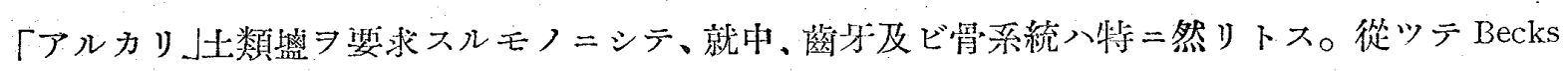

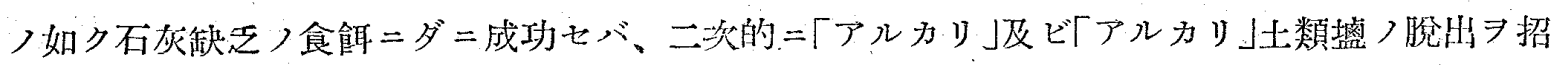
來スル吾人ノ食慨性「アチドージス」下略ボ同栐ナル成果二到達スベキ筈ナリ。然レドモ Becks

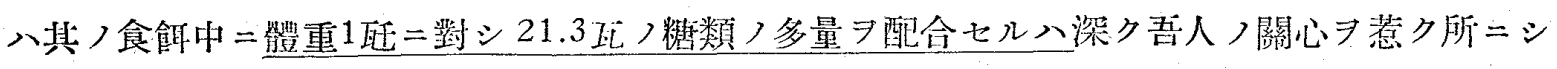
テ、果シテ然ラバ、氏ノ實驗入單＝Vitamin D 缺乏、Kalkarmutノノミナラズ、同時二糖類ノ 
過剩攝取試驗 遂行セルモノト言ハザル可ラズ。

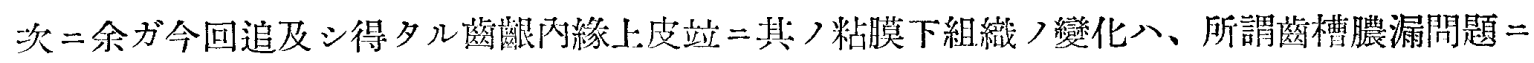
對シテ殊二重大ナル意舱ヨ有スルモノトス。例之 Chiavaro ノ指摘七ルガ如キ Paradentitis， 初期ニ於テ認メラレ將來組織ノ缺損 (Gewebsdefekte) =移行スベキ運命タ有スル組織ノ損傷

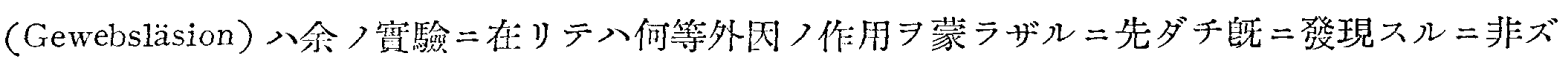

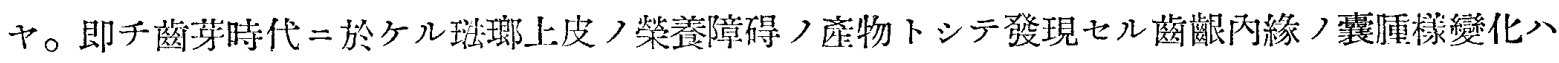

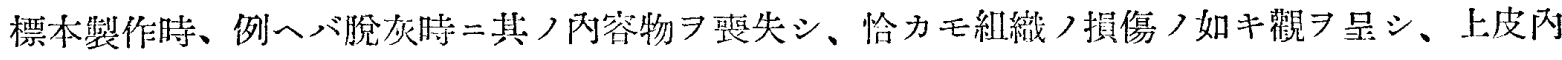
侟裂ノ形態习採リ、其ノ度つ强度ナルモノ八上皮队缺損下シテ發現スルモノトス。一方二於テ

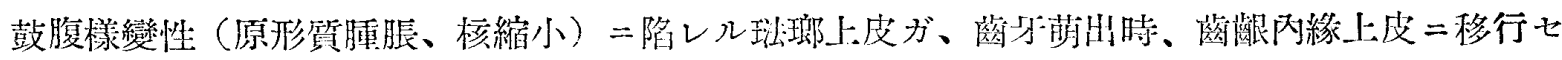
ル場合八、之レ亦、發炎時二認メラル、上皮緗胞ノ浮腫二類似スルモノナリ。且ツ又、榮養障

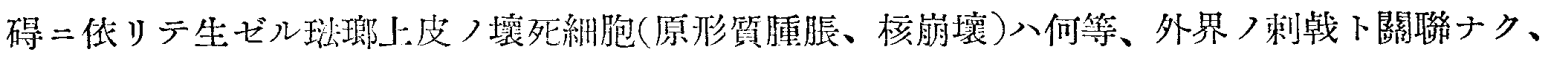

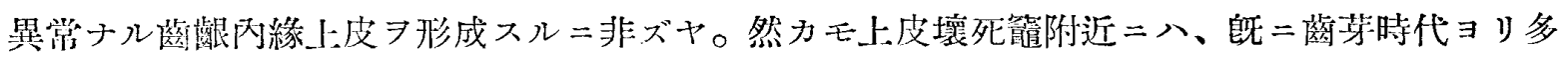
核白血球ノ浸㵎ヨ件ヒテ、恰カモ炎症へノ反應二酷似スルモノトス。尚興味深キ入榮養障碍時

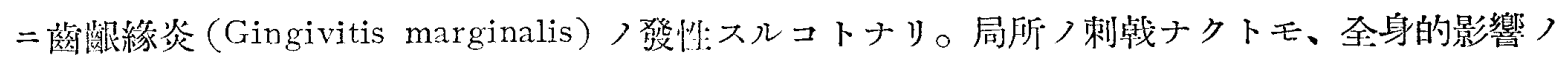

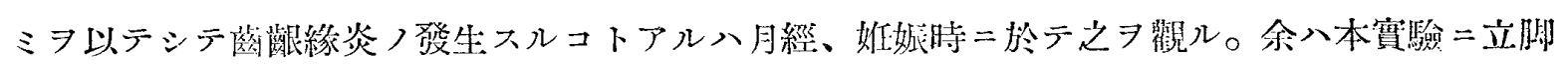

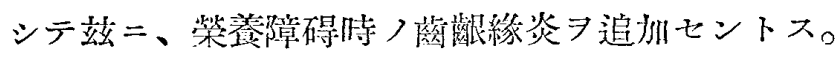

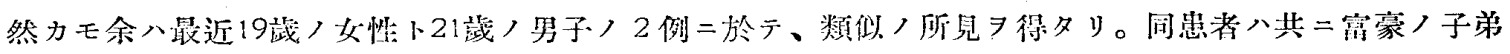

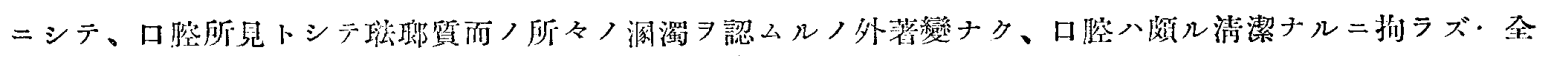

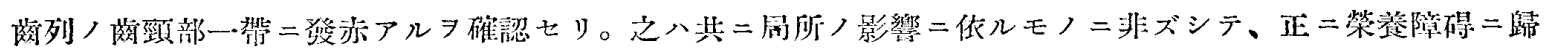

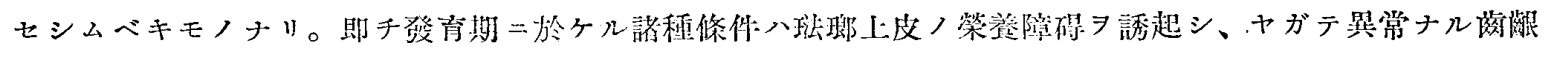

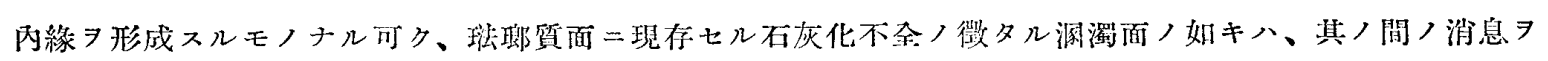

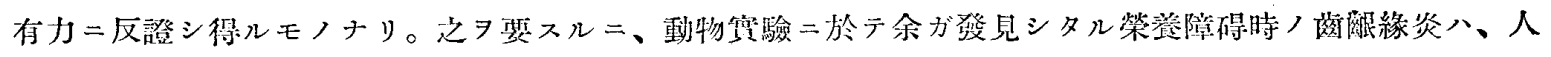
類ニモ發現シ得ル叮能性 タ磪信シ得タリ。

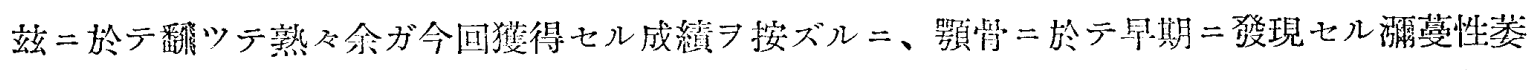

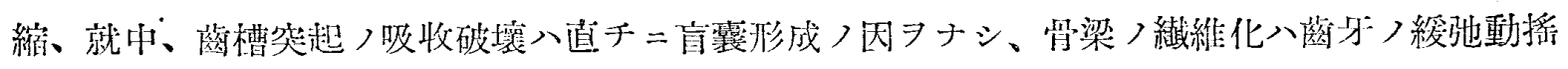

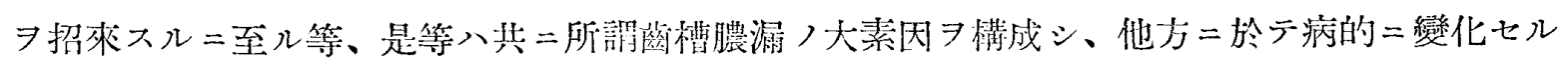

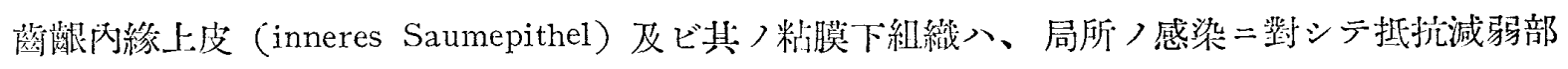

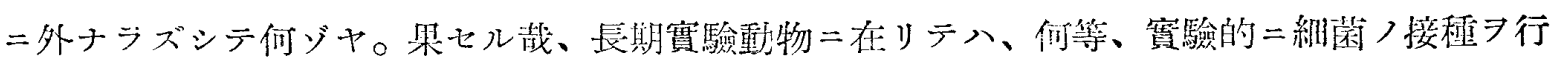

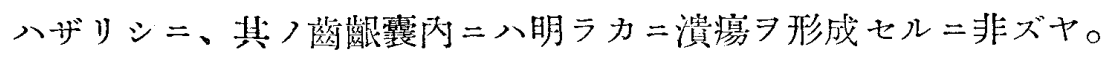

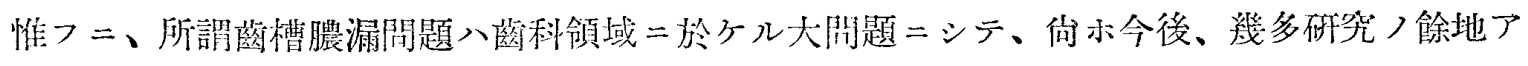

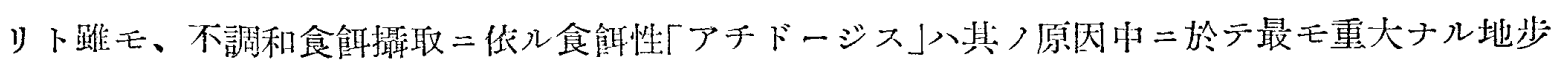

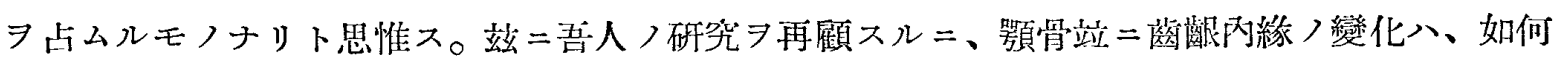

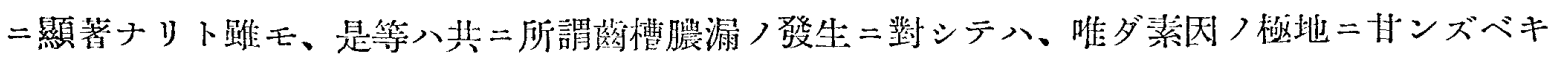




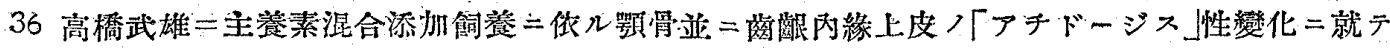

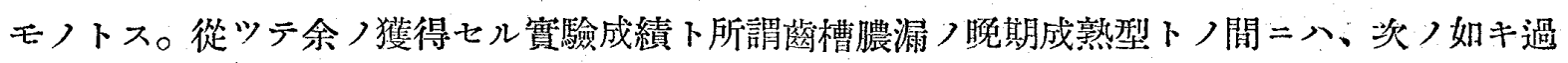
程ヨ想像シ得ルモノナリ。

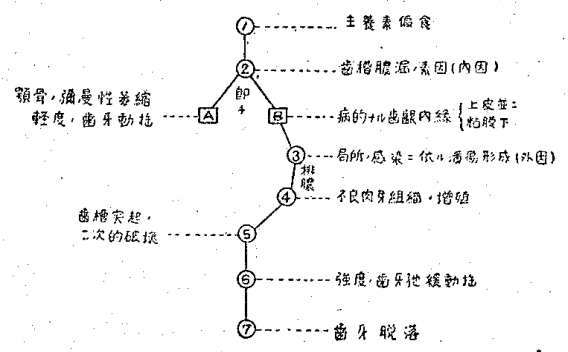

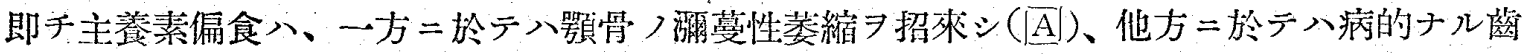

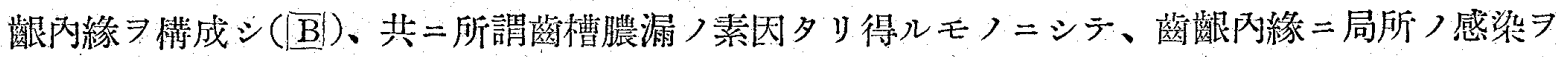

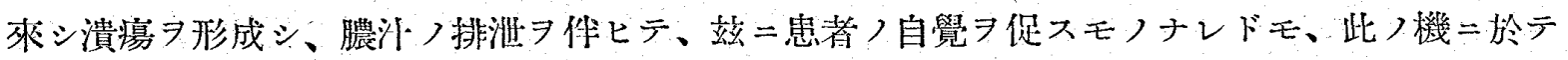

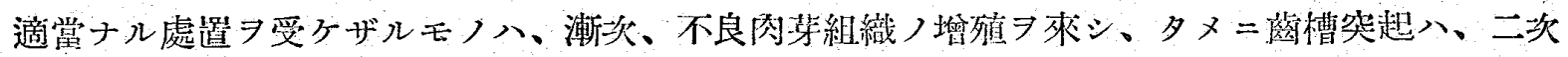

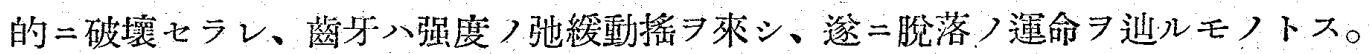

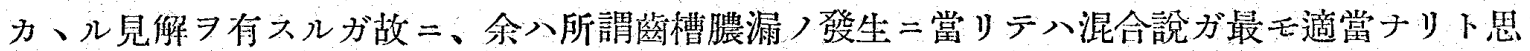
惟スルモノナリ。サレド、食ガ弦二高調措ク能ハザルハ、重大ナル素因ア有スルモノハ、極又

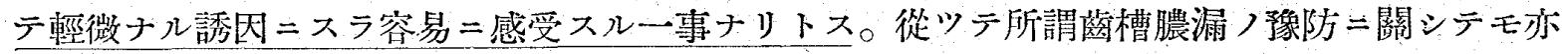

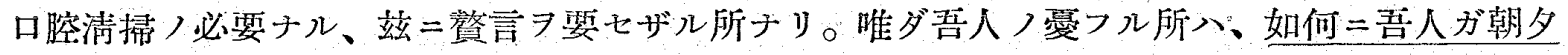

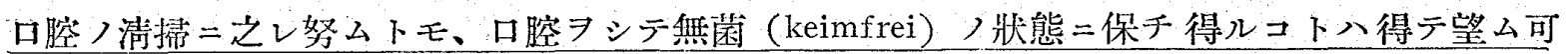

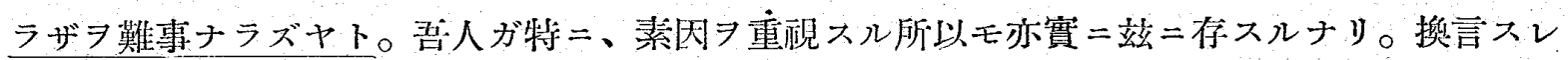

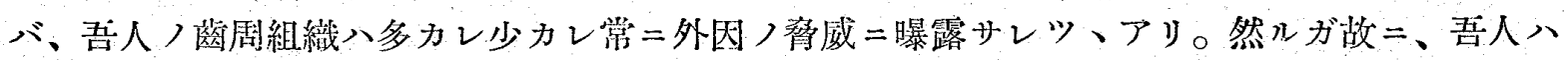

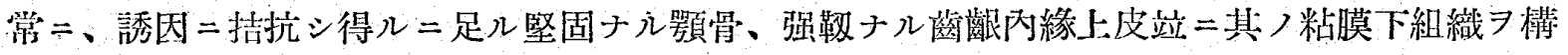

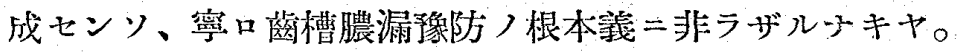

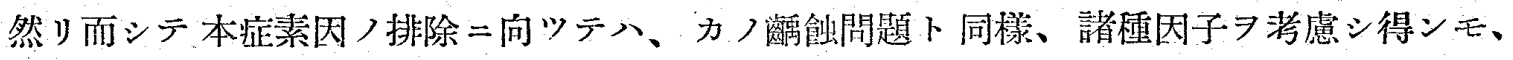
特二發育期二於ヶル血液「アチドージス」發生ヨ抑制セザル可ラズ。例之、噘二糖類つ過剩攝取

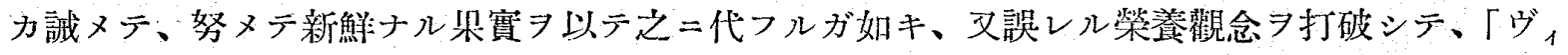
タミン」「カルシウム」二富メル新㶍ナル野㭉 キ、又ハ同ジク闪食卜雖モ、蛋白質二大例減 庫タル朋臟フ膾采スルガ如キハえレナリ。

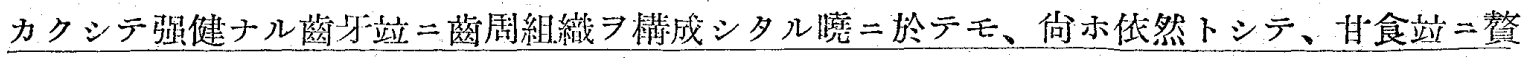

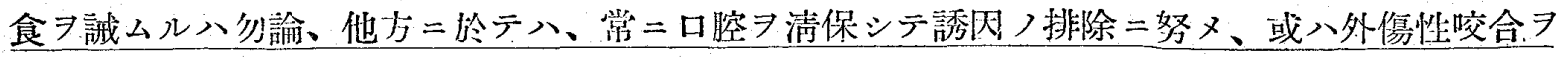

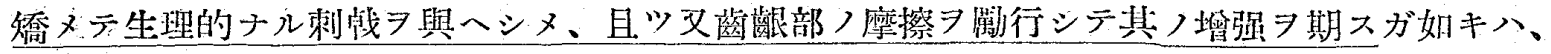
正二豫防逼科整學ノ妙諦タラズンバアラズ。 


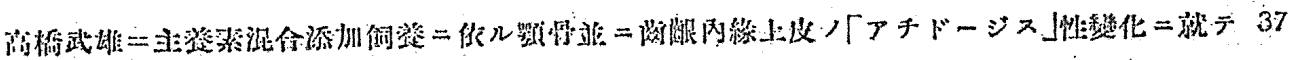

\section{第四䓥結論}

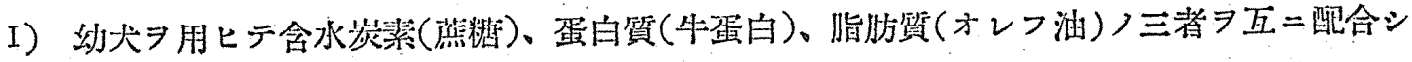

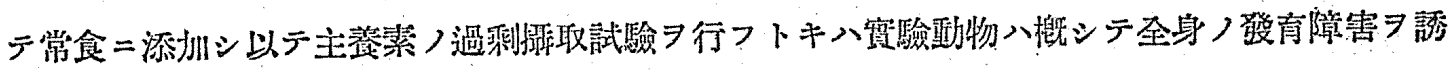
起スルモノナリ。

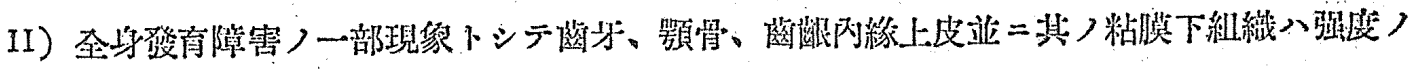
病的變化习招隶スルモノトス。

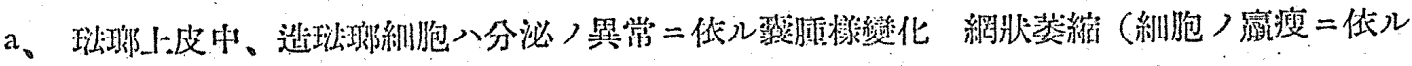

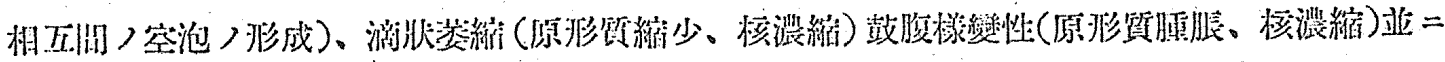

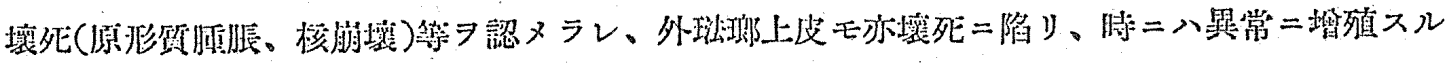
コトアリ。

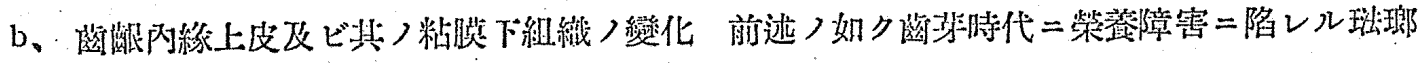

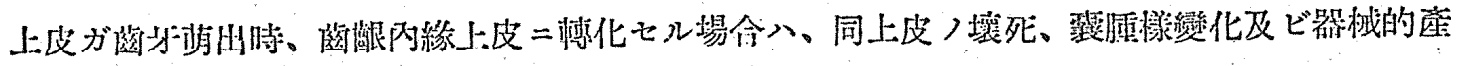

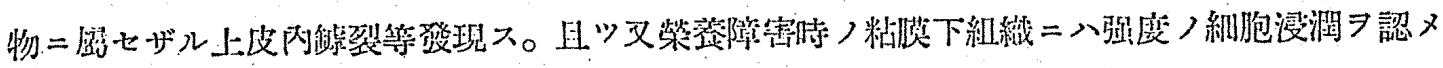

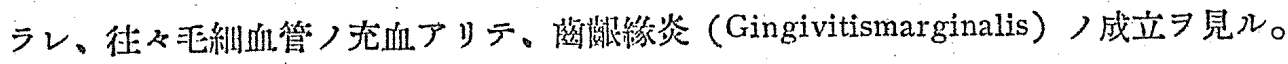

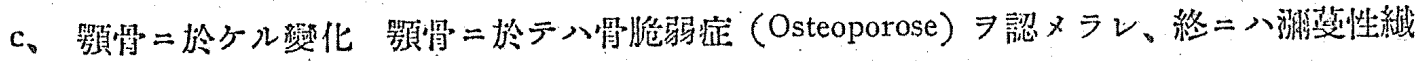

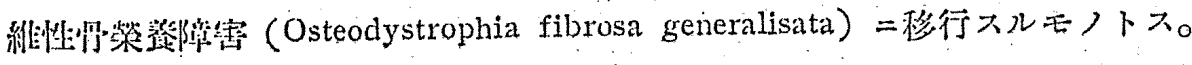

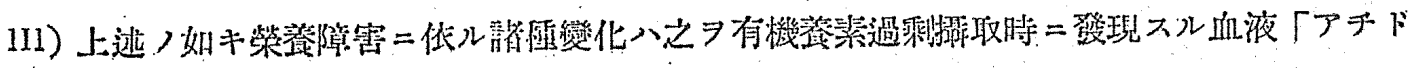

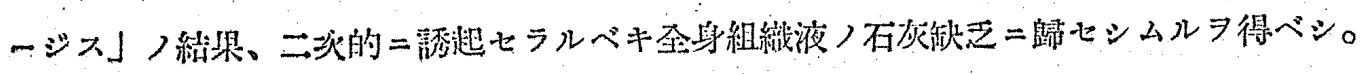

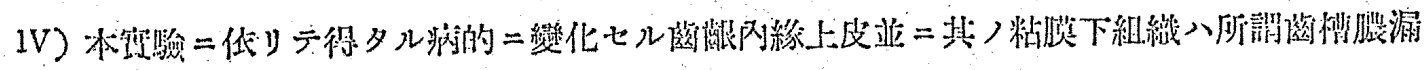

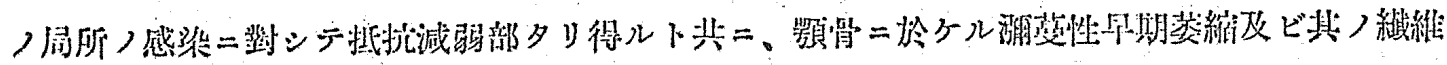

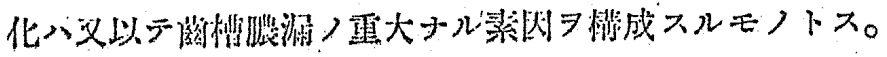

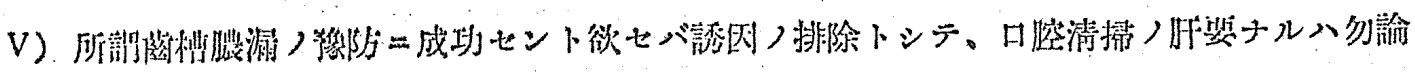

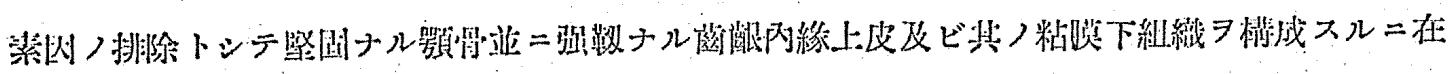

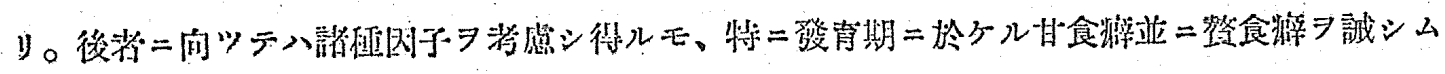
ベキモノトス。

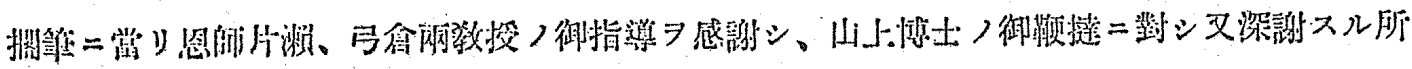
ナリ。 